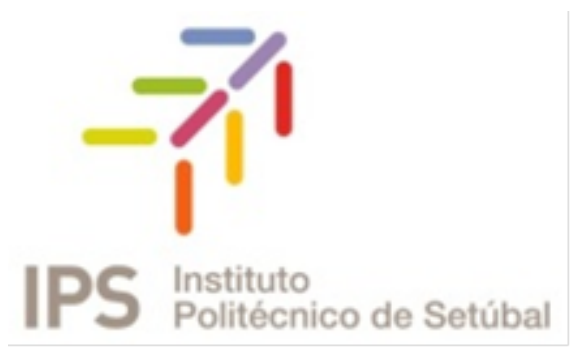

\title{
Da Educação Superior para o Mercado de Trabalho: a inserção profissional dos licenciados no IPS
}

fevereiro 2013

Núcleo de Planeamento - Observatório de Inserção na Vida Ativa 


\section{Conteúdo}

INTRODUÇÃO

1 - Da Educação Superior para o Mercado de Trabalho.............................................................................. 4

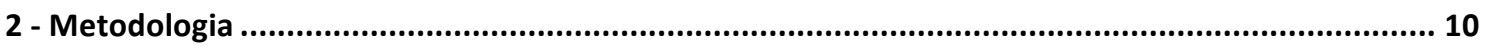

2.1 - Caracterização da População em Análise .............................................................................. 11

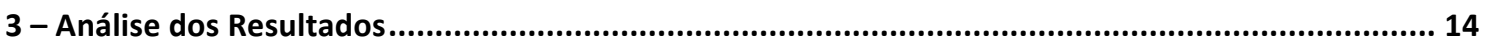

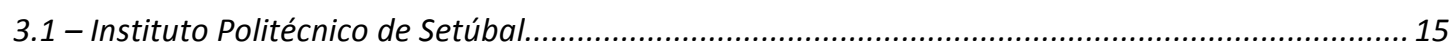

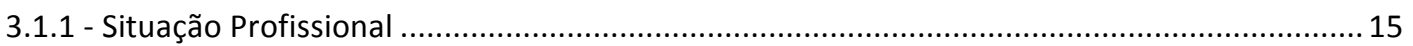

3.1.2 - Tipo de empresa/organização, localização geográfica e nível de remuneração..................... 18

3.1.3 - Meios de acesso ao emprego......................................................................................... 20

3.1.4 - Relação entre o emprego e a área de formação académica ................................................ 21

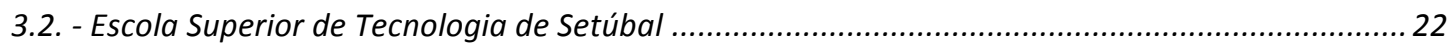

3.2.1 - Situação Profissional ....................................................................................................... 23

3.2.2 - Tipo de empresa/organização, localização geográfica e nível de remuneração ...................... 26

3.2.3 - Meios de acesso ao emprego ......................................................................................... 29

3.2.4 - Relação entre o emprego e a área de formação académica ............................................... 30

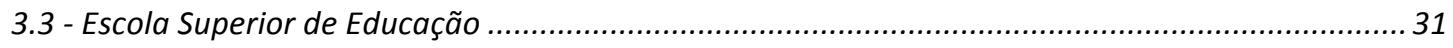

3.3.1 - Situação Profissional ........................................................................................................ 32

3.3.2 - Tipo de empresa/organização, localização geográfica e nível de remuneração.....................36

3.3.3 - Meios de acesso ao emprego ........................................................................................ 38

3.3.4 - Relação entre o emprego e a área de formação académica .............................................. 39

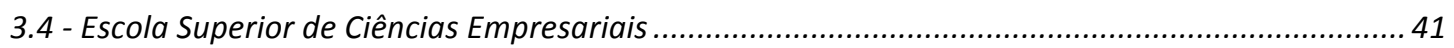

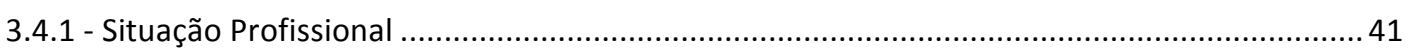

3.4.2 - Tipo de empresa/organização, localização geográfica e nível de remuneração ..................... 45

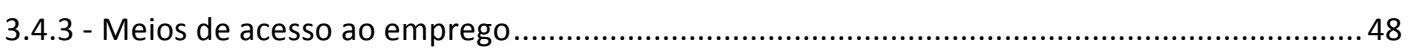

3.4.4 - Relação entre o emprego e a área de formação académica ............................................. 49

3.5 - Escola Superior de Tecnologia do Barreiro ....................................................................... 51

3.5.1 - Situação Profissional .......................................................................................................... 51

3.5.2 - Tipo de empresa/organização, localização geográfica e nível de remuneração ....................54

3.5.3 - Meios de acesso ao emprego............................................................................................5 57

3.5.4 - Relação entre o emprego e a área de formação académica .................................................5 57

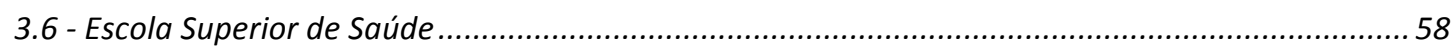

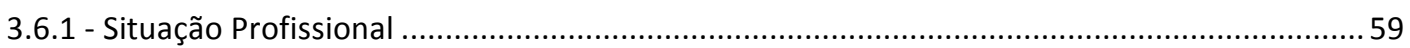

3.6.2 - Tipo de empresa/organização, localização geográfica e nível de remuneração.....................62

3.6.3 - Meios de acesso ao emprego ....................................................................................... 64

3.6.4 - Relação entre o emprego e a área de formação académica ..............................................65

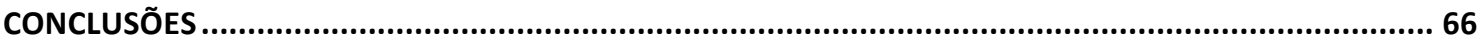

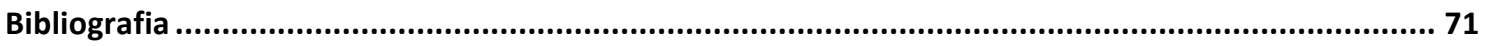




\section{INTRODUÇÃO}

A integração efetiva, no mercado de trabalho, dos diplomados com formação académica superior tem despoletado, nos últimos anos, um renovado interesse nas instituições de ensino, nas políticas educativas e de emprego e na sociedade em geral.

Com efeito, apesar do crescimento da frequência do ensino superior e do aumento progressivo de diplomados, o atual contexto de crise económica, marcado, essencialmente, pela incerteza, instabilidade e precariedade laboral, tem condicionado o processo de inserção profissional dos jovens que saem da escola para acederem ao mercado de emprego.

Neste sentido, para que cada instituição de ensino possa ser mais atuante no processo de transição dos seus diplomados para a vida ativa e, simultaneamente, adaptar a sua oferta formativa, torna-se fundamental acompanhar, de uma forma sistemática, a trajetória profissional dos mesmos.

É neste quadro que este trabalho apresenta os resultados do estudo desenvolvido no âmbito do Observatório de Inserção na Vida Ativa do Instituto Politécnico de Setúbal (OIVA/IPS), que tem como objetivo analisar o percurso profissional dos licenciados no IPS, um ano após a obtenção do grau académico, a partir dos resultados de um inquérito por questionário aplicado aos licenciados no IPS no ano letivo 2010/2011.

Objetiva-se, igualmente, explanar os resultados atinentes às variáveis do estudo, nomeadamente, a situação profissional e o vínculo laboral dos licenciados empregados, as diferenças de género no acesso ao emprego, os níveis salariais, a caracterização das entidades empregadoras e, a relação existente entre a profissão e a área de formação académica, tendo presente as assimetrias existentes entre as escolas do IPS e, em particular, entre os diversos cursos ministrados. Discutirse-á, ainda, e sempre que possível, os resultados obtidos com estudos semelhantes realizados para outras Instituições de Ensino Superior.

O presente relatório encontra-se dividido em quatro capítulos principais. No primeiro capítulo é apresentada a revisão da literatura relevante para a discussão da problemática da inserção profissional dos diplomados no mercado de trabalho. Seguidamente, no segundo capítulo, descrevese a metodologia de investigação, os objetivos e os instrumentos de recolha de dados utilizados.

Na terceira parte do relatório procede-se à análise e discussão dos resultados obtidos nas diversas variáveis em estudo, ao nível do IPS, por escola e curso ministrado. Por fim, no último capítulo destacam-se as principais conclusões apresentando-se ainda algumas reflexões em torno das diferenças existentes entre a situação profissional dos licenciados do IPS. 


\section{1 - Da Educação Superior para o Mercado de Trabalho}

De acordo com os dados disponibilizados pela Direção Geral de Estatística da Educação e Ciência assiste-se, nos últimos anos, a um aumento progressivo de diplomados no ensino superior. No ano letivo de 2009/2010 já se verificava um aumento de 3,4 pontos percentuais em relação ao ano anterior mas, no ano letivo 2010/2011 esse crescimento foi de 10,8 pontos percentuais. De referir ainda que, neste último ano, ao contrário do verificado em anos anteriores, o número de diplomados no ensino superior público politécnico registou um aumento de $8 \%$, uma vez que se assistiu a um crescimento de diplomados, neste subsistema de ensino, nos cursos de mestrado, pós graduação e especialização tecnológica.

Para Oliveira e Temudo (2008), verifica-se também, nos últimos anos, um aumento substancial do número de mulheres a aceder ao ensino superior. Os dados estatísticos disponibilizados pelo Gabinete de Planeamento, Estratégia, Avaliação e Relações Internacionais (GPEARI) sustentam essas afirmações, evidenciando o crescimento do número de mulheres a frequentar o ensino superior. No ano letivo de 2010/2011 encontravam-se inscritas, pela primeira vez, no ensino superior cerca de 184.627 mulheres o que representa um aumento de $12 \%$ relativamente ao ano letivo de 2005/2006.

Com efeito, apesar do atual contexto de crise, marcado, essencialmente, pela incerteza, instabilidade e precariedade laboral, tem-se verificado um acentuado crescimento na frequência do ensino superior e, subsequente aumento de diplomados. De acordo com Guerreiro e Abrantes (2007, p. 67) muitos dos jovens que abandonaram precocemente o seu percurso académico tendem a retomar os seus estudos no sentido de adquirirem maiores qualificações e novas competências para enfrentarem "um mercado de trabalho em acelerada transformação". Para os autores, a valorização profissional e a integração efetiva no mercado de trabalho são os principais fatores que explicam o reingresso ao sistema de ensino.

Também Oliveira e Temudo (2008) apontam a afirmação individual e a consolidação e progressão numa profissão já adquirida, como as principais razões de ingresso na vida académica. Para Costa (2011), o investimento na carreira e a possibilidade de alcançar novas perspetivas profissionais só conseguidas através da obtenção de um novo grau académico, ao nível superior, parecem também representar uma parte significativa das razões invocadas.

Pinto (2012) refere ainda que, a expetativa de obtenção de melhores oportunidades de emprego e, simultaneamente a possibilidade de auferirem um salário mais alto, influenciam a decisão de prossecução dos estudos ao nível superior. Com efeito, de acordo com o relatório publicado pela Organização para a Cooperação e o Desenvolvimento Económico (OCDE, 2012) o curso superior 
continua a ser a garantia de auferir um salário mais alto uma vez que, na média dos países da OCDE, um indivíduo com habilitação superior pode aspirar a ganhar um salário $55 \%$ mais alto, do que um indivíduo com o ensino secundário. Portugal é, segundo o resultado do relatório, um dos países onde esta diferença salarial é mais evidente. Um licenciado português poderá esperar ganhar mais $69 \%$ que um indivíduo sem grau académico superior - a maior taxa de rentabilidade económica obtida pela posse de um diploma superior, de entre todos os países da OCDE.

Apesar de nos últimos anos existirem mudanças significativas no que diz respeito aos processos de transição da escola para o mercado de trabalho, o aumento de estudantes no ensino superior prende-se, essencialmente, pela relação existente entre a obtenção do grau académico como principal requisito de acesso ao emprego. Conforme referem Gonçalves et al (2006), o diploma promove a inserção profissional, sendo a taxa de desemprego entre os diplomados do ensino superior substancialmente inferior à dos não diplomados. Silva (2007) cit in Vinagreiro (2008) aponta ainda que, o diploma do ensino superior favorece, não só, a inserção na vida ativa, mas também o acesso a uma maior estabilidade em termos de vínculo contratual, melhor remuneração e maiores possibilidades de progressão na carreira. No entanto, o atual contexto de crise e o aumento do desemprego tem condicionado o processo de inserção profissional dos jovens que concluem o ensino superior para acederem ao mercado de emprego.

De acordo com as estatísticas publicadas pelo GPEARI (2011) deparamo-nos com uma evolução significativa da taxa de desemprego entre os diplomados do ensino superior. Em dezembro de 2011 o número de desempregados cresceu significativamente passando de 49.826 (dezembro de 2010) para 63.470 , correspondendo a um incremento de $27,4 \%$.

Também no que diz respeito às taxas de desemprego por género, verifica-se que são substancialmente superiores no género feminino. De facto, de acordo com os dados do GPEARI (2011), em cada três desempregados, um é homem e dois são mulheres.

Para Gonçalves et al (2006) no plano do emprego, são as mulheres, nos diferentes países europeus, que se deparam com maiores dificuldades em alcançar uma posição estável no mercado de trabalho, comparativamente com os homens, registando, aquelas, taxas de desemprego mais elevadas. Alves (2004) corrobora estas afirmações, referindo ainda que, na análise efetuada aos diplomados do ensino superior, os homens inserem-se, em maior número, nos escalões mais elevados de remuneração.

Guerreiro e Pereira (2006) referem, ainda, que as mulheres encontram, em contexto profissional, maiores dificuldades de progressão na carreira, tendo em conta que as empresas preferem profissionais do sexo masculino sem responsabilidades familiares e com disponibilidade quase 
total. As autoras referem, ainda, que continuam a aumentar as assimetrias de género no mercado de trabalho, resultando em menores oportunidades de carreira para as mulheres sendo, por isso, as mais abrangidas pela precariedade laboral.

Oliveira e Temudo (2008) cit in Costa (2011), sustentam que as motivações das mulheres estudantes do ensino superior se prendem, essencialmente, com o seu desenvolvimento e investimento pessoal e que, ao nível profissional, o investimento na carreira para obtenção de maiores oportunidades de progressão e a promoção sociocultural representam algumas das razões mais significativas do investimento destas mulheres num grau académico superior.

Face ao atual quadro de desemprego em Portugal bem como às exigências impostas pela legislação, as instituições de ensino preocupam-se, cada vez mais, com a inserção profissional dos seus diplomados, pelo que, se assiste à criação no seio destas instituições, de gabinetes de apoio à inserção profissional, onde são divulgadas ofertas de emprego e realizados “...cursos breves, de prática de psicotécnicos e/ou de preparação do comportamento dos licenciados perante os entrevistadores/potenciais recrutadores, a divulgação de novas oportunidades de emprego e a elaboração de estudos sobre saídas profissionais." (Gonçalves et al, 2006, p. 106).

Para Alves e Ambrósio (2005, p. 5) os observatórios de inserção e acompanhamento profissional têm como principal objetivo fornecer informação relevante para que seja possível avaliar mais facilmente o sistema de ensino e formação, refletindo sobre reformas eventualmente necessárias, e também para "...vigiar o sistema de emprego, suas necessidades e exigências..." sendo que a divulgação dos resultados obtidos, através dos observatórios, poderá ser “...útil também no planeamento da formação contínua, fornecendo informações que permitam favorecer o ajustamento entre indivíduos e postos de trabalho".

Segundo Hilter (2002) cit in Pinto (2012) existem fatores que potenciam a inserção profissional dos diplomados. De acordo com o autor, a instituição de ensino onde o licenciado obteve o seu grau académico poderá beneficiar a integração no mercado de trabalho. Para Alves (2004), os diplomados no sistema de ensino superior público apresentam taxas de desemprego mais baixas, denotando-se que o ensino público beneficia de algum "prestígio social" que se traduz numa maior facilidade de integração dos diplomados na vida profissional. Para a autora, são sobretudo os diplomados das universidades que beneficiam de melhores condições de inserção e perspetivas de emprego. No entanto, no que diz respeito ao sistema de ensino público e, de acordo com os dados disponibilizados pelo GPEARI (2011), são as universidades públicas que apresentam taxas de desemprego superiores comparativamente com os institutos politécnicos públicos. Em dezembro de 2011, as taxas de desemprego dos diplomados do ensino superior correspondiam a $10,5 \%$ do 
desemprego total (encontravam-se inscritos no IEFP 605.134 indivíduos, entre eles, 63.470 diplomados do ensino superior) e, neste universo de diplomados desempregados, verifica-se que o politécnico apresenta uma taxa inferior aos $36,3 \%$ das universidades existindo, no entanto, realidades distintas entre estes dois subsistemas de ensino, de acordo com as diferentes áreas de estudo e cursos que oferecem.

No que concerne aos domínios disciplinares que oferecem melhores oportunidades de entrada na vida ativa, Alves (2006) aponta as áreas das Engenharias, Economia e Informática, uma vez que as taxas de desemprego entre os diplomados nestas áreas são as mais baixas. 0 relatório sobre 0 desemprego, publicado pelo GPEARI, consubstancia estes resultados. Com efeito, a Dezembro de 2011 as áreas de estudo com menor registo de desempregados com habilitação superior são as Engenharias, Informática e Matemática/Estatística. Por outro lado, conforme refere Alves (2007) as taxas de desemprego mais altas encontram-se entre os diplomados nas áreas da Formação de Professores/Formadores e Ciências da Educação.

No que diz respeito ao vínculo contratual, segundo Alves (2007), são os diplomados nas áreas das Ciências Empresariais e de Informática que detém uma maior estabilidade contratual uma vez que são entre estes que se verificam taxas mais altas de contrato de trabalho sem termo. Os diplomados em Humanidades enfrentam, na sua maioria, uma menor estabilidade contratual uma vez que, o vínculo mais frequente é o do contrato de trabalho com termo (a prazo).

Também Alves (2005, p. 97), no seu estudo sobre as trajetórias académicas e de inserção profissional dos licenciados da Universidade de Lisboa conclui que, maioritariamente, o primeiro contacto dos diplomados, com o mercado de trabalho, "assume uma forma precária mas a tempo inteiro". Para $74,1 \%$ dos licenciados, inquiridos nesse estudo, a modalidade de trabalho independente, através dos recibos verdes é uma realidade, que se traduz, na maioria dos casos, numa situação de vulnerabilidade contratual.

Almeida et al (2007) concluem, no seu estudo junto dos diplomados da Escola Superior de Ciências Empresariais do IPS, que após a conclusão da licenciatura, 29\% dos estudantes que ingressaram no mercado de trabalho, no seu primeiro emprego, estabeleceram com as entidades empregadoras um contrato de trabalho por tempo indeterminado, sendo os licenciados nos cursos de Contabilidade e Finanças e Gestão de Sistemas de Informação, os menos expostos à precariedade do vínculo contratual. Contudo, cerca de $61 \%$ desses diplomados referem possuir atualmente um contrato de trabalho por tempo indeterminado, evidenciando-se uma inversão da situação contratual face ao primeiro emprego. Para Almeida et al (2007, p. 25), este aumento de estabilidade do primeiro emprego para o atual "significa que a antiguidade no mercado de 
trabalho, ao garantir a aquisição de experiência profissional, tende a aumentar a probabilidade de acesso a um emprego estável...".

Conforme refere Marques (2009), deparamo-nos ainda, em contexto de trabalho, com uma certa flexibilização das remunerações auferidas pelos licenciados, oscilando o salário médio entre ao 751 e os 1.000 euros, verificando-se a existência de uma relação significativa entre o salário e o vínculo contratual. Para a autora, os diplomados que se encontram em situação de estágio ou de recibos verdes estão sujeitos a remunerações mais baixas, comparativamente com os que detêm um vínculo permanente de trabalho. Alves (2005) consubstancia estas afirmações apontando que o salário auferido depende, ainda, do tipo de empresa empregadora, da classificação final na licenciatura e do curso frequentado.

Marques (2009, p. 96) defende, ainda, que no mercado de trabalho esta "flexibilização salarial", é justificada pelos empregadores, por se encontrar relacionada com a falta de experiência profissional dos diplomados e, concomitantemente, pelas funções hierárquicas que os mesmos desempenham, assistindo-se, em Portugal, a uma política de “...baixos salários como fator de competitividade associada a uma tendência para a sobrequalificação dos jovens quadros...".

Contudo, conforme refere Vinagreiro (2008), os cursos superiores que oferecem estágios curriculares apresentam oportunidades importantes para os diplomados, uma vez que thes confere alguma experiência profissional. Marques (2009) defende, ainda, que a existência desses estágios potenciam, para além da aquisição de novos conhecimentos por parte dos estagiários, a transição da escola para o mercado de trabalho o que, muitas vezes, se traduz num emprego efetivo.

De acordo com Almeida et al (2007), cerca de 59\% dos diplomados na ESCE/IPS (desde 1999/2000 até 2005/2006) continuaram a trabalhar na empresa/organização onde realizaram o seu estágio curricular.

Por outro lado, segundo Pinto (2012), os diplomados do ensino superior deparam-se ainda, no mercado de trabalho, com outro fator relevante: a desadequação do emprego às competências adquiridas ao longo da licenciatura verificando-se, nalguns casos, que os licenciados desempenham funções com baixo nível de complexidade, tendo em conta as suas qualificações.

A inserção bem sucedida, na vida ativa, pauta-se também pela integração numa profissão diretamente relacionada com a área de formação do diplomado. Alves (2005) conclui que a grande maioria dos diplomados da Universidade de Lisboa que fazem parte do seu estudo, exercem a sua atividade profissional na área do curso em que se formaram. Também Marques (2009), no estudo efetuado junto dos diplomados da Universidade do Minho, conclui que são essencialmente os 
diplomados nas áreas das Tecnologias e Engenharias que maior correspondência encontram entre o emprego que detêm e a licenciatura em que se diplomaram. Por outro lado, de acordo com a autora, cerca de 75\% dos diplomados nas áreas das "Humanidades e Ciências Sociais" assumem ter um emprego onde as atividades desenvolvidas são diferentes da sua formação académica.

Porém, importa referir que o grau académico, por si só, não garante o acesso a um emprego. Para Marques (2009), cabe também aos diplomados aumentarem as qualificações obtidas com a habilitação superior, procurando complementar a sua formação e apostarem numa atualização constante dos saberes e nas competências relacionadas com a responsabilidade, iniciativa, polivalência, capacidade de trabalho em equipa, entre outras. Tomlinson (2012) refere ainda que, por forma a facilitar a integração efetiva no mercado de trabalho, os diplomados deverão apostar em atividades extracurriculares que favoreçam a aquisição de experiência profissional e competências transversais, algumas vezes adquiridas através do voluntariado, uma vez que complementam o grau académico obtido e são muito valorizadas pelos empregadores.

Machado dos Santos (2001) cit in Gonçalves et al (2006, p. 106) aponta também a importância dos diplomados entrarem no mercado de trabalho apresentando competências ao nível das capacidades, valores e atitudes, nomeadamente as relacionadas com "a boa educação geral, conhecimento de línguas, competências de comunicação e em tecnologias de informação, bom aspeto ou capacidade de trabalho em equipa". 


\section{2 - Metodologia}

O enquadramento teórico construído funcionou como base para a estruturação da parte empírica deste trabalho, para a escolha das variáveis a serem utlizadas e para a operacionalização metodológica do estudo, nomeadamente no que diz respeito à identificação dos objetivos, à seleção das técnicas de recolha de dados a adotar e à construção do instrumento utilizado.

Sendo o principal objetivo deste estudo, compreender e caracterizar o processo de transição dos licenciados do IPS, no ano letivo 2010/2011, para o mundo do trabalho, optou-se por uma abordagem que privilegia a recolha de dados quantitativos com recurso ao inquérito por questionário, por melhor se ajustar aos objetivos do estudo e à população abrangida.

O questionário, constituído por 16 questões, na sua maioria fechadas, com um conjunto diversificado de alternativas de resposta, foi estruturado por forma a dar resposta às questões relacionadas com a situação profissional, o vínculo contratual, o tempo de trabalho, o tipo de empresa ou organização onde trabalham, o concelho, o rendimento mensal líquido, a relação existente entre a profissão e a formação académica e a forma de obtenção do emprego por parte dos inquiridos.

Após a redação da primeira versão do questionário efetuou-se um pré teste, no sentido de aferir a clareza das perguntas, junto de um conjunto de diplomados. A aplicação do pré teste permitiu, fundamentalmente, perceber se as questões formuladas eram facilmente compreendidas pelos inquiridos e possibilitou a reformulação de algumas questões. Para o efeito, o questionário foi aplicado durante o mês de dezembro de 2011, enviado por correio eletrónico, tendo os inquiridos sido informados do propósito do estudo e do seu carácter confidencial. De referir que, por se ter verificado uma fraca resposta através desta via (cerca de 200 questionários válidos), tornou-se necessário inquirir telefonicamente os diplomados em estudo, tendo em vista aumentar o número de respondentes.

Como ferramenta estatística para análise dos dados recolhidos, utilizou-se o programa Statistical Package for the Social Sciences (SPSS). 


\section{1 - Caracterização da População em Análise}

O universo de análise desta investigação são os licenciados que concluíram os seus estudos no ano letivo de 2010/2011, da Escola Superior de Tecnologia de Setúbal (ESTS/IPS), da Escola Superior de Educação (ESE/IPS), da Escola Superior de Ciências Empresariais (ESCE/IPS), da Escola Superior de Tecnologia do Barreiro (ESTB/IPS) e da Escola Superior de Saúde (ESS/IPS), pertencentes ao Instituto Politécnico de Setúbal (IPS).

Tendo presentes os dados fornecidos pela Sistema de Informação do IPS, o universo de licenciados corresponde a 813, nos diversos cursos ministrados nas unidades orgânicas do IPS. Conforme se pode aferir no quadro infra, é na ESCE/IPS e, especificamente o curso de Contabilidade e Finanças, que se encontra o maior número de diplomados (300 e 69 respetivamente). Estes dados estão em consonância com o número de estudantes da escola, embora no caso da EST Setúbal/IPS o número de licenciados sejam consideravelmente menor que na ESCE/IPS, apesar de possuir um número semelhante de estudantes de licenciatura, e pouco acima da ESE/IPS, quando possui quase o dobro dos estudantes. 
Quadro 1 - Distribuição do número de licenciados e respondentes por curso

\begin{tabular}{|c|c|c|c|c|}
\hline U. 0. & Licenciaturas & $\begin{array}{c}\mathrm{N} .{ }^{\circ} \text { de } \\
\text { Licenciados }\end{array}$ & $\begin{array}{c}\mathrm{N} .^{0} \text { de } \\
\text { Respondentes }\end{array}$ & $\begin{array}{c}\% \text { de } \\
\text { resposta }\end{array}$ \\
\hline \multirow{8}{*}{ ESTS/IPS } & Engenharia do Ambiente & 23 & 17 & $74 \%$ \\
\hline & Engenharia de Automação, Controlo e Instrumentação & 8 & 7 & $88 \%$ \\
\hline & Engenharia Biomédica & 34 & 25 & $74 \%$ \\
\hline & Engenharia Eletrotécnica e Computadores & 38 & 31 & $82 \%$ \\
\hline & Engenharia Informática & 36 & 30 & $83 \%$ \\
\hline & Engenharia Mecânica & 25 & 20 & $80 \%$ \\
\hline & Tecnologia e Gestão Industrial (regime noturno) & 16 & 12 & $75 \%$ \\
\hline & TOTAL ESTS/IPS & 180 & 142 & $79 \%$ \\
\hline \multirow{7}{*}{ ESE/IPS } & Animação e Intervenção Sociocultural & 18 & 15 & $83 \%$ \\
\hline & Comunicação Social & 30 & 24 & $80 \%$ \\
\hline & Educação Básica & 56 & 46 & $82 \%$ \\
\hline & Desporto & 13 & 10 & $77 \%$ \\
\hline & Promoção Artística e Património & 27 & 21 & $78 \%$ \\
\hline & Tradução e Interpretação da Língua G. Portuguesa & 11 & 8 & $73 \%$ \\
\hline & TOTAL ESE/IPS & 155 & 124 & $80 \%$ \\
\hline \multirow{9}{*}{ ESCE/IPS } & Contabilidade e Finanças & 69 & 43 & $62 \%$ \\
\hline & Contabilidade e Finanças (regime noturno) & 39 & 30 & $77 \%$ \\
\hline & Gestão da Distribuição e da Logística & 39 & 30 & $77 \%$ \\
\hline & Gestão da Distribuição e da Logística (regime pós laboral) & 13 & 10 & $77 \%$ \\
\hline & Gestão de Recursos Humanos & 53 & 39 & $74 \%$ \\
\hline & Gestão de Recursos Humanos (regime pós laboral) & 15 & 12 & $80 \%$ \\
\hline & Gestão de Sistemas de Informação & 22 & 22 & $100 \%$ \\
\hline & Marketing & 50 & 37 & $74 \%$ \\
\hline & TOTAL ESCE/IPS & 300 & 223 & $74 \%$ \\
\hline \multirow{6}{*}{ ESTB/IPS } & Engenharia Civil & 23 & 19 & $83 \%$ \\
\hline & Engenharia Civil (regime noturno) & 26 & 21 & $81 \%$ \\
\hline & Engenharia Química & 1 & 1 & $100 \%$ \\
\hline & Gestão da Construção & 5 & 5 & $100 \%$ \\
\hline & Gestão da Construção (regime noturno) & 12 & 8 & $67 \%$ \\
\hline & TOTAL ESTB/IPS & 67 & 54 & $81 \%$ \\
\hline \multirow{4}{*}{ ESS/IPS } & Enfermagem & 49 & 34 & $69 \%$ \\
\hline & Fisioterapia & 47 & 26 & $55 \%$ \\
\hline & Terapia da Fala & 15 & 11 & $73 \%$ \\
\hline & TOTAL ESS/IPS & 111 & 71 & $64 \%$ \\
\hline \multicolumn{2}{|r|}{ TOTAL IPS } & 813 & 614 & $76 \%$ \\
\hline
\end{tabular}

Fonte: Sistema de Informação do IPS, novembro de 2012 
Relativamente à distribuição por género, podemos afirmar que, dos 813 licenciados, 472 são do género feminino e os restantes 341 são do género masculino. Como podemos constatar, nos cursos de Educação Básica, Engenharia Química e Terapia da Fala, o universo de diplomados é constituído apenas por mulheres. Em 11, dos restantes 26 cursos, a população dominante é do género masculino, especialmente nas licenciaturas em Engenharias e Desporto. Em todos os outros cursos são as mulheres que, em maior número, se licenciaram, denotando-se uma forte tendência de feminização entre os diplomados do IPS, conforme se pode constatar no gráfico abaixo.

Gráfico 1 - Distribuição do número de licenciados por género

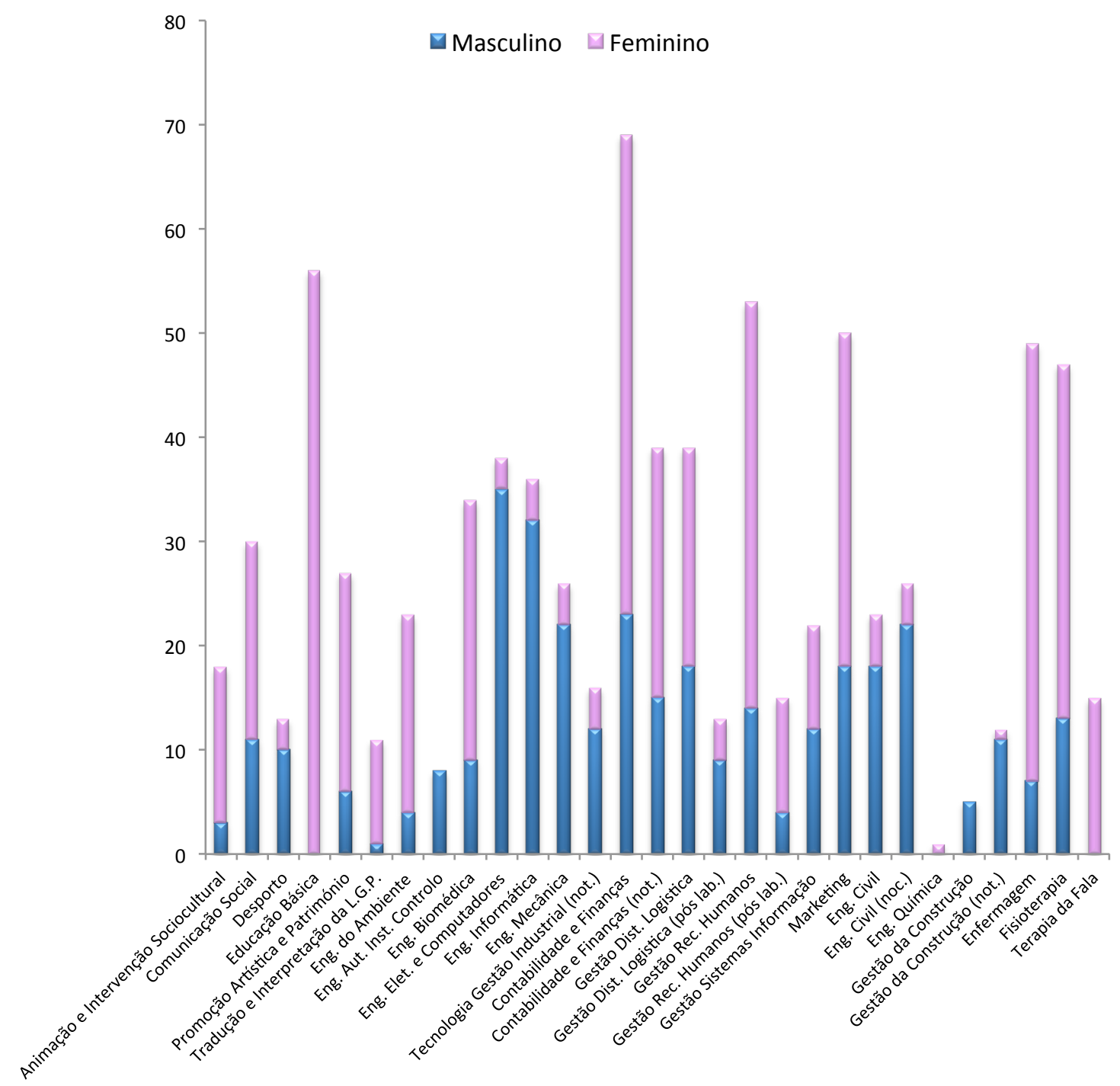

Fonte: Sistema de Informação do IPS, novembro de 2012 


\section{3-Análise dos Resultados}

Neste capítulo pretende-se analisar os principais resultados empíricos obtidos com o estudo, tendo em conta os objetivos anteriormente definidos. No que diz respeito à amostra, obtiveram-se 614 respostas válidas, o que representa $76 \%$ do universo. As percentagens de resposta variam consoante o curso, existindo casos, nomeadamente nos cursos de Gestão de Sistemas de Informação, Engenharia Química e Gestão da Construção cuja taxa se situa nos 100\%, e outros como Contabilidade e Finanças, Gestão da Construção (regime noturno), Enfermagem e Fisioterapia, onde as taxas de resposta são inferiores a 70\%, conforme se podem aferir no quadro 1. No entanto, estas taxas de resposta comparam favoravelmente com outros estudos sobre esta temática, nomeadamente o estudo de Marques (2007) onde a taxa de resposta foi de cerca de $40 \%$.

Apresenta-se, ainda, a distribuição do número de respondentes por género e situação profissional efetuando-se, posteriormente, a análise dos resultados relativos às variáveis em estudo. Para mais fácil compreensão, a análise dos resultados obtidos será efetuada ao nível do IPS e por unidade orgânica. 


\section{1 - Instituto Politécnico de Setúbal}

No que diz respeito à distribuição dos inquiridos, por género, constata-se que a amostra é maioritariamente feminina (55,9\%) sendo, na ESE/IPS, na ESCE/IPS e na ESS/IPS que se encontra uma maior representação das mulheres, conforme gráfico 2.

Gráfico 2 - Distribuição dos inquiridos do IPS por escola e género

Masculino Feminino

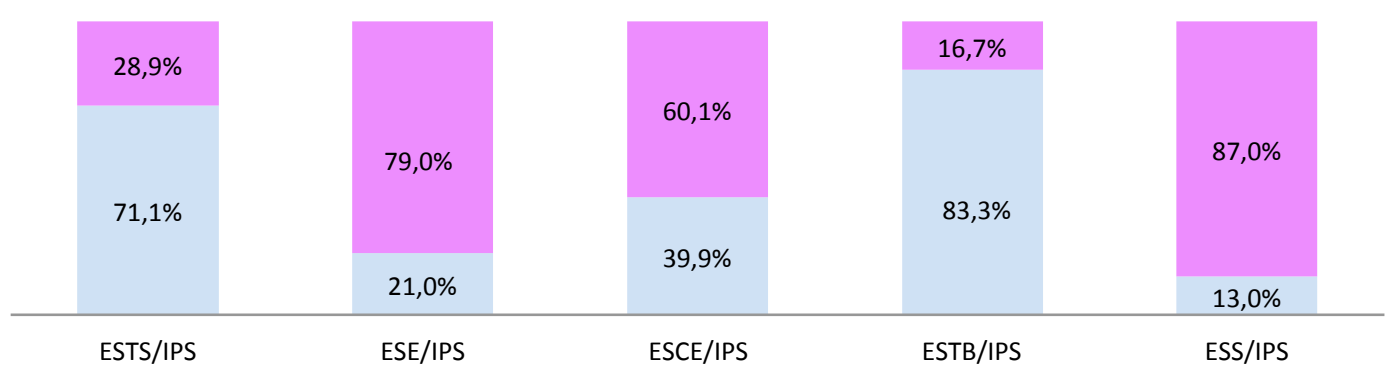

Fonte: Inquérito por questionário

\subsection{1 - Situação Profissional}

Do universo de inquiridos são sobretudo as mulheres que se encontram em situação de desemprego (21,6\% de mulheres desempregadas e 13,4\% de homens desempregados) sendo, também as mulheres que claramente apostam na prossecução dos seus estudos (9,1\% de mulheres e $5,2 \%$ de homens). Destaca-se o facto de que, atualmente, $81,4 \%$ dos homens licenciados no IPS, intervenientes no estudo, estão inseridos no mercado de trabalho através de situação de emprego ou realização de estágio profissional estando, na mesma situação, cerca de 69,3\% das mulheres inquiridas.

Gráfico 3 - Situação profissional dos inquiridos licenciados do IPS por género

$$
\text { Homens Mulheres }
$$

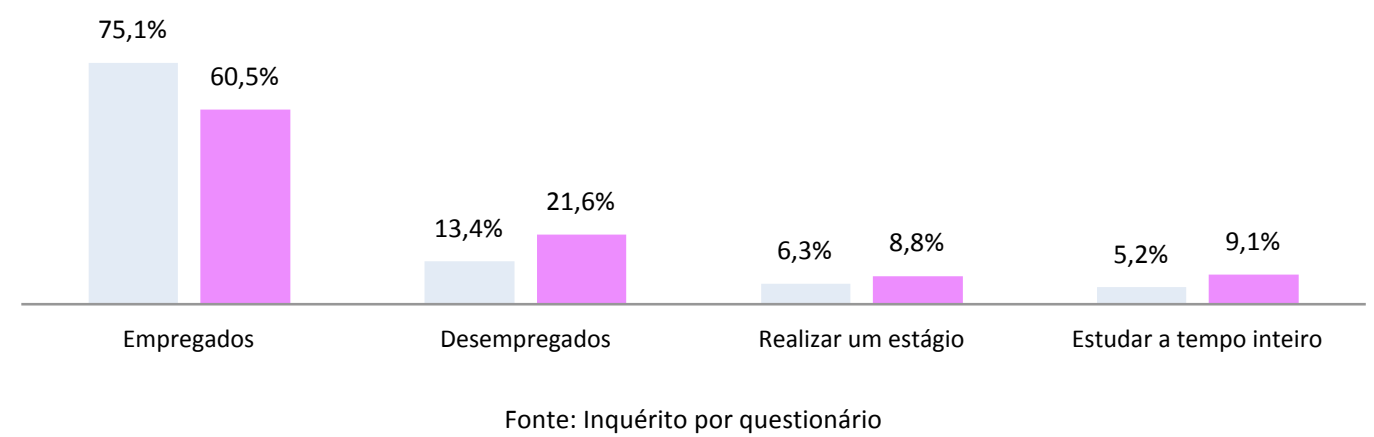


Na globalidade, encontram-se empregados cerca de $67 \%$ dos licenciados inquiridos denotando-se que a ESCE/IPS e a ESS/IPS apresentam as taxas de emprego mais altas (71,2\% e $78,3 \%$ respetivamente). 0 desemprego, afetando $18 \%$ dos inquiridos, encontra maior expressão entre os licenciados na ESE/IPS e na ESTB/IPS, sendo também a ESE/IPS que apresenta a mais alta taxa de licenciados a estudar a tempo inteiro $(17,7 \%)$. O estágio profissional surge como a situação profissional para cerca de $7,7 \%$ dos inquiridos.

Quadro 2 - Situação profissional dos inquiridos licenciados do IPS

\begin{tabular}{|l|c|c|c|c|}
\hline & Empregado & Realizar estágio & Desempregado & $\begin{array}{c}\text { Estudar a } \\
\text { tempo inteiro }\end{array}$ \\
\hline ESTS/IPS & $68,3 \%$ & $9,9 \%$ & $14,1 \%$ & $7,7 \%$ \\
\hline ESE/IPS & $51,6 \%$ & $4,8 \%$ & $25,8 \%$ & $17,7 \%$ \\
\hline ESCE/IPS & $71,2 \%$ & $9,5 \%$ & $15,3 \%$ & $4,0 \%$ \\
\hline ESTB/IPS & $66,7 \%$ & $1,9 \%$ & $25,9 \%$ & $5,5 \%$ \\
\hline ESS/IPS & $78,3 \%$ & $7,2 \%$ & $14,5 \%$ & $0,0 \%$ \\
\hline TOTAL IPS & $\mathbf{6 6 , 9 \%}$ & $\mathbf{7 , 7}$ & $\mathbf{1 8 , 0} \%$ & $\mathbf{7 , 4 \%}$ \\
\hline
\end{tabular}

Fonte: Inquérito por questionário

Como se pode aferir, no quadro 4 , são $85,2 \%$ os licenciados que trabalham por conta de outrem sendo apenas $13,6 \%$ os que trabalham por conta própria. Contudo, entre os licenciados da ESS/IPS o trabalho por conta própria assume a realidade de $46,6 \%$ dos inquiridos empregados.

Quadro 3 - Situação na profissão dos inquiridos licenciados do IPS

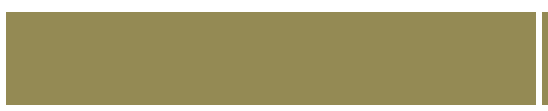

\section{Trabalhador por conta de outrem}

ESTS/IPS

ESE/IPS

ESCE/IPS

ESTB/IPS

ESS/IPS

TOTAL IPS
$95,9 \%$

$84,4 \%$

$92,4 \%$

$77,8 \%$

$53,4 \%$

$85,2 \%$

Fonte: Inquérito por questionário

\section{Trabalhador por conta própria}

$3,1 \% \quad 1,0 \%$

$10,9 \%$

$4,7 \%$

$7,0 \%$

$0,6 \%$

$22,2 \%$

$0,0 \%$

$46,6 \%$

$0,0 \%$

$13,6 \%$

$1,2 \%$

Relativamente ao vínculo contratual mantido pelos inquiridos com as entidades empregadoras conclui-se que cerca de $47,3 \%$ possuem um contrato de trabalho sem termo beneficiando assim, de alguma estabilidade contratual, sendo o contrato a prazo o vínculo mantido por $37,1 \%$ dos licenciados empregados. 
Da análise por escola, verifica-se que são os licenciados da ESTB/IPS, ESTS/IPS e da ESCE/IPS que, em maior número, estabeleceram um contrato sem termo com as entidades empregadoras, sendo a ESE/IPS e a ESS/IPS os que apresentam maior precariedade, em termos de vínculo. Com efeito, é entre os diplomados da ESS/IPS que se encontra uma maior diversificação nas relações de trabalho existentes $(13,8 \%$ com contrato sem termo, $34,5 \%$ com contrato a prazo, $37,9 \%$ com contrato de prestação de serviços, 5,2\% trabalham ocasionalmente e 8,6\% indicam ainda possuir outra situação).

Gráfico 4 - Vínculo laboral, por curso, dos inquiridos licenciados do IPS

Contrato sem termo $\quad$ Contrato a prazo Contrato de Prestação de Serviços
Trabalho ocadional (biscates) Outra Situação

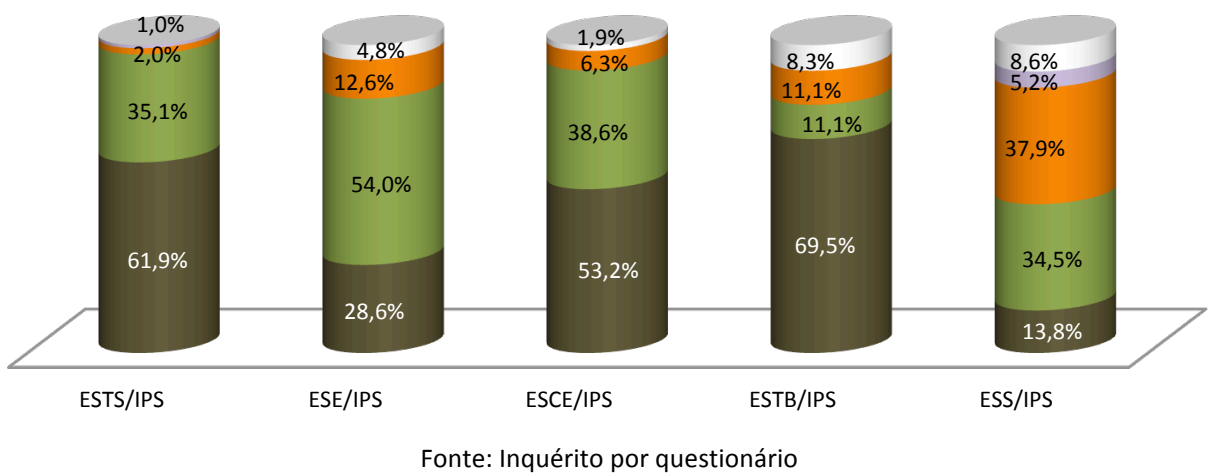

O emprego a tempo inteiro é praticado pela maioria dos licenciados empregados representando $88,1 \%$ do universo dos inquiridos empregados, estando apenas $11,9 \%$ a trabalhar a tempo parcial. É sobretudo na ESE/IPS e na ESS/IPS onde o trabalho a tempo parcial se assume como a realidade de cerca de $20 \%$ dos inquiridos, estando mais de $90 \%$ dos licenciados das restantes escolas do IPS a trabalhar a tempo inteiro.

Gráfico 5 - Duração do tempo de trabalho, por escola, dos inquiridos licenciados do IPS

- Tempo Inteiro Tempo Parcial

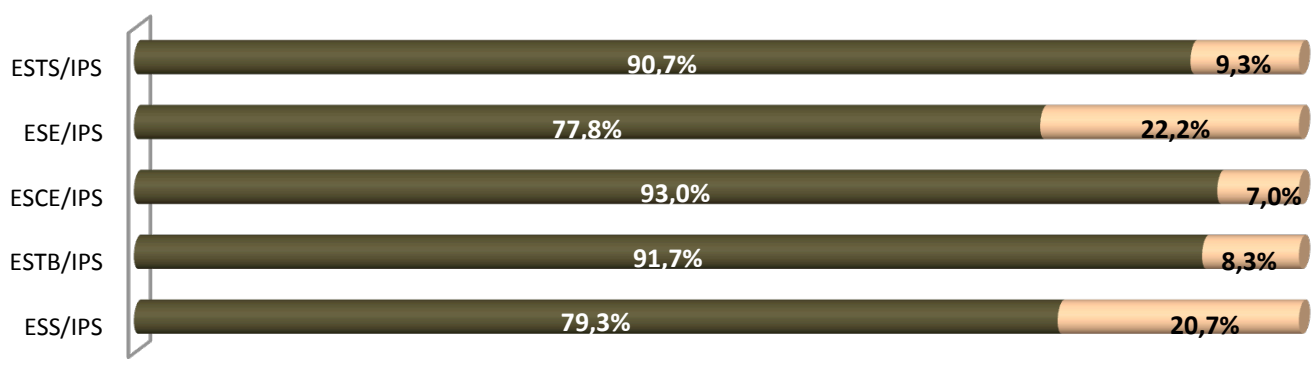

Fonte: Inquérito por questionário 


\subsection{2 - Tipo de empresa/organização, localização geográfica e nível de remuneração}

O setor privado emprega cerca de $75 \%$ dos licenciados no IPS e, apenas $20,5 \%$ dos inquiridos trabalham em organismos públicos. No setor privado, são as pequenas e médias empresas que empregam grande parte dos inquiridos $(45,4 \%)$ estando, ainda, aproximadamente $30 \%$ dos licenciados empregados a trabalhar em empresas privadas com 100 ou mais trabalhadores.

Gráfico 6 - Tipo de empresa/organização onde trabalham os inquiridos licenciados do IPS

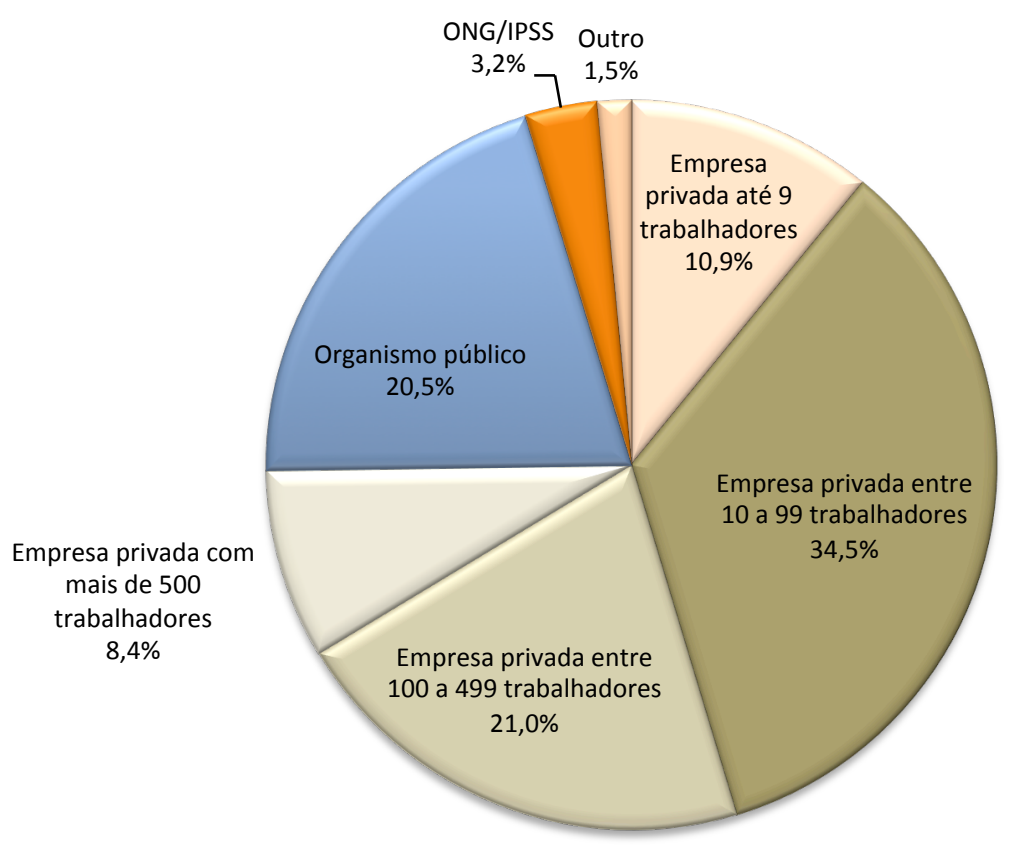

Fonte: Inquérito por questionário

Através do quadro infra podemos concluir que são sobretudo os licenciados da ESTB/IPS e da ESS/IPS que se encontram inseridos no setor público (30,6\% e 29,9\%, respetivamente) e, em particular no caso da ESS/IPS nas ONG/IPSS (12,3\%).

As empresas privadas com mais de 99 trabalhadores são as principais empregadoras dos licenciados da ESTS/IPS (36,3\%) e na ESCE/IPS $(36,1 \%)$ verificando-se que nas pequenas empresas, com menos de 10 trabalhadores, encontram-se inseridos, essencialmente, os inquiridos empregados da ESTB/IPS (19,4\%) e da ESS/IPS (19,3\%). 
Quadro 4 - Dimensão da empresa/organização onde trabalham os inquiridos licenciados do IPS

\begin{tabular}{|c|c|c|c|c|c|c|c|}
\hline & $\begin{array}{c}\text { Empresa } \\
\text { Privada até } 9 \\
\text { trabalhadores }\end{array}$ & $\begin{array}{c}\text { Empresa Privada } \\
\text { entre } 10 \text { a } 99 \\
\text { trabalhadores }\end{array}$ & $\begin{array}{c}\text { Empresa } \\
\text { Privada entre } \\
100 \text { a } 499 \\
\text { trabalhadores }\end{array}$ & $\begin{array}{l}\text { Empresa Privada } \\
\text { com mais de } 500 \\
\text { trabalhadores }\end{array}$ & $\begin{array}{l}\text { Organismos } \\
\text { Públicos }\end{array}$ & ONG/IPSS & Outro \\
\hline ESTS/IPS & $4,3 \%$ & $42,9 \%$ & $27,5 \%$ & $8,8 \%$ & $16,5 \%$ & $0,0 \%$ & $0,0 \%$ \\
\hline ESE/IPS & $16,0 \%$ & $32,3 \%$ & $12,9 \%$ & $8,1 \%$ & $22,6 \%$ & $8,1 \%$ & $0,0 \%$ \\
\hline ESCE/IPS & $7,7 \%$ & $36,7 \%$ & $25,3 \%$ & $10,8 \%$ & $16,4 \%$ & $0,6 \%$ & $2,5 \%$ \\
\hline ESTB/IPS & $19,4 \%$ & $25,0 \%$ & $19,4 \%$ & $5,6 \%$ & $30,6 \%$ & $0,0 \%$ & $0,0 \%$ \\
\hline ESS/IPS & $19,2 \%$ & $22,8 \%$ & $8,8 \%$ & $3,5 \%$ & $29,9 \%$ & $12,3 \%$ & $3,5 \%$ \\
\hline TOTAL IPS & $11,0 \%$ & $34,4 \%$ & $21,0 \%$ & $8,4 \%$ & $20,5 \%$ & $3,2 \%$ & $1,5 \%$ \\
\hline
\end{tabular}

Os setores da saúde e ação social (16,8\%), dos serviços prestados às empresas (16\%), indústria transformadora $(14,3 \%)$, comércio $(14,1 \%)$ e transportes e comunicações $(9,1 \%)$ são os mais apontados pelos inquiridos empregados. Menos expressivos entre os licenciados empregados são os setores da administração pública central $(5,7 \%)$, administração pública local $(4,9 \%)$ e educação $(4,9 \%)$.

Relativamente à localização geográfica das entidades empregadoras, as mesmas situam-se essencialmente em Lisboa e Setúbal (31,7\% e 22,9\%, respetivamente). Palmela surge também como como um dos locais mais apontados $(9,7 \%)$ destacando-se, ainda, que $2,2 \%$ dos inquiridos trabalham fora de Portugal ( $1,7 \%$ em países da União Europeia e $0,5 \%$ em países fora do espaço europeu).

Gráfico 7 - Localização geográfica da empresa/organização onde trabalham os inquiridos licenciados do IPS

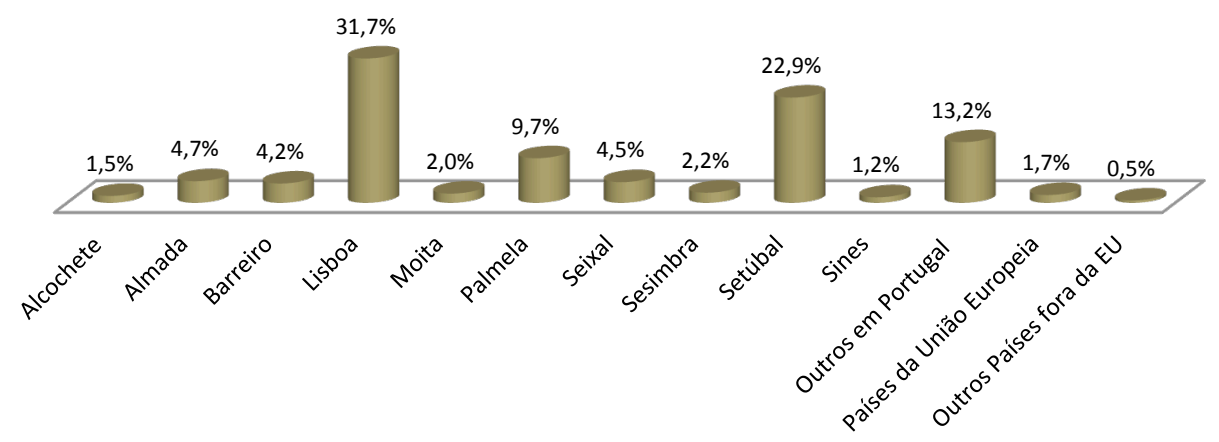

Fonte: Inquérito por questionário 
No que diz respeito ao escalão remuneratório onde se encontram inseridos os inquiridos empregados constata-se que $36,7 \%$ auferem um salário líquido mensal entre os $751 €-1.000 €$ sendo este o escalão com maior expressão. A auferir mais de $1.000 €$ estão cerca de $19,6 \%$ e, com uma remuneração até $250 €$, encontram-se $2,3 \%$.

Da análise por escola conclui-se que são os licenciados da ESE/IPS que em maior número se inserem no escalão de rendimento mais baixo (37,9\% aufere um salário líquido igual ou inferior a $500 €)$. Por outro lado, são sobretudo os licenciados nas escolas de engenharia que auferem salários superiores a $1.250 €$ (21,9\% da ESTB/IPS e $19,6 \%$ da ESTS/IPS).

Quadro 5 - Remuneração mensal líquida, por curso, dos inquiridos licenciados do IPS

\begin{tabular}{|c|c|c|c|c|c|c|}
\hline & Até $250 €$ & $251-500 €$ & $501-750 €$ & $\begin{array}{c}751- \\
1.000 €\end{array}$ & $\begin{array}{l}1.001- \\
1.250 €\end{array}$ & $\begin{array}{c}\text { Mais de } \\
1.250 €\end{array}$ \\
\hline ESTS/IPS & $2,1 \%$ & $9,8 \%$ & $18,5 \%$ & $43,5 \%$ & $6,5 \%$ & $19,6 \%$ \\
\hline ESE/IPS & $6,9 \%$ & $31,0 \%$ & $43,1 \%$ & $17,2 \%$ & $1,8 \%$ & $0,0 \%$ \\
\hline ESCE/IPS & $1,3 \%$ & $10,1 \%$ & $30,9 \%$ & $37,6 \%$ & $8,7 \%$ & $11,4 \%$ \\
\hline ESTB/IPS & $0,0 \%$ & $12,4 \%$ & $21,9 \%$ & $31,3 \%$ & $12,5 \%$ & $21,9 \%$ \\
\hline ESS/IPS & $1,9 \%$ & $7,5 \%$ & $26,4 \%$ & $47,2 \%$ & $7,5 \%$ & $9,5 \%$ \\
\hline TOTAL IPS & $2,3 \%$ & $13,0 \%$ & $28,4 \%$ & $36,7 \%$ & $7,3 \%$ & $12,3 \%$ \\
\hline
\end{tabular}

Fonte: Inquérito por questionário

\subsection{3 - Meios de acesso ao emprego}

Aos inquiridos que estão a trabalhar foi perguntado de que forma se inseriram no mercado de trabalho, concluindo-se que cerca de $23,8 \%$ obtiveram o emprego através de candidatura espontânea, sendo este o meio mais utilizado pelos licenciados aquando da sua entrada na vida ativa. Cerca de $13,6 \%$ entraram no mercado de trabalho através dos contactos de amigos ou colegas e $11,7 \%$ indicam ter sido através da resposta a anúncios em jornais e revistas.

O acesso ao emprego através dos centros de emprego $(1,1 \%)$, das empresas de trabalho temporário $(1,1 \%)$, através de um professor $(0,7 \%)$ ou através da criação da própria empresa $(0,7 \%)$ são os menos apontados pelos inquiridos.

Importa referir que, pese embora os inquiridos pudessem indicar, nas suas opções de resposta, que se mantiveram no emprego que já detinham no decorrer da licenciatura, essa opção não foi considerada na análise deste indicador. Optou-se por esta metodologia uma vez que, o que se 
pretende apurar se relaciona com os meios utilizados pelos recém licenciados na procura de emprego, assumindo-se que quem possui um emprego não efetua esse esforço ativo para alcançar esse desiderato.

$\mathrm{Na}$ análise por escola pode, ainda, concluir-se que o serviço de apoio à inserção profissional disponibilizado pela ESTS/IPS é identificado, por 19,4\% dos inquiridos, como o principal potenciador da inserção dos mesmos na vida ativa, sendo a candidatura espontânea a mais apontada (29\%).

Na ESE/IPS também a candidatura espontânea surge como o principal meio de acesso ao emprego $(36,2 \%)$, sendo a rede de contactos de amigos e familiares indicado por $17 \%$ dos inquiridos.

Por outro lado, na ESCE/IPS, o estágio curricular assume-se como o primeiro contato dos estudantes com a vida profissional surgindo como principal meio de acesso ao emprego uma vez que $21,2 \%$ dos licenciados inquiridos ficaram a trabalham nas empresas onde estagiaram.

Na ESTB/IPS a inserção numa atividade profissional remunerada deu-se através de concurso público $(32 \%)$ e de candidatura espontânea (20\%), sendo este último o meio mais utilizado pelos licenciados da ESS/IPS $(33,3 \%)$ no acesso ao emprego.

Quadro 6 - Meios de acesso ao emprego, dos inquiridos licenciados do IPS

\begin{tabular}{|c|c|c|c|c|c|c|c|c|c|c|c|c|c|c|c|c|}
\hline & 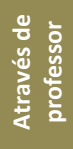 & $\begin{array}{l}\text { 은 을 } \\
\text { 흥 흘 } \\
\text { 을 }\end{array}$ & 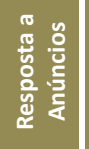 & 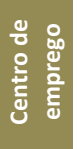 & 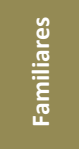 & 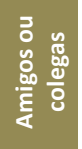 & 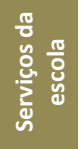 & 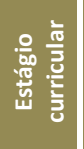 & 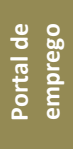 & 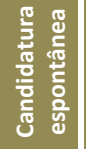 & 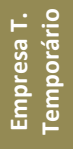 & 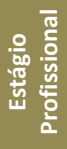 & 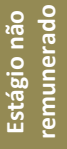 & 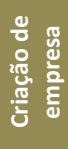 & 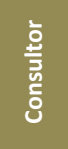 & $\frac{\text { 율 }}{\frac{5}{3}}$ \\
\hline ESTS/IPS & $3,2 \%$ & $0,0 \%$ & $16,1 \%$ & $0,0 \%$ & $12,9 \%$ & $9,7 \%$ & $19,4 \%$ & $0,0 \%$ & $6,5 \%$ & $29,0 \%$ & $0,0 \%$ & $3,2 \%$ & $0,0 \%$ & $0,0 \%$ & $0,0 \%$ & $0,0 \%$ \\
\hline ESE/IPS & $0,0 \%$ & $14,9 \%$ & $6,4 \%$ & $0,0 \%$ & $2,1 \%$ & $17,0 \%$ & $0,0 \%$ & $2,1 \%$ & $2,1 \%$ & $36,2 \%$ & $0,0 \%$ & $6,4 \%$ & $0,0 \%$ & $0,0 \%$ & $4,3 \%$ & $8,5 \%$ \\
\hline ESCE/IPS & $0,9 \%$ & $6,2 \%$ & $17,7 \%$ & $0,0 \%$ & $4,4 \%$ & $14,2 \%$ & $0,0 \%$ & $21,2 \%$ & $9,7 \%$ & $13,3 \%$ & $1,8 \%$ & $6,2 \%$ & $0,0 \%$ & $0,0 \%$ & $0,9 \%$ & $3,5 \%$ \\
\hline ESTB/IPS & $0,0 \%$ & $32,0 \%$ & $8,0 \%$ & $0,0 \%$ & $0,0 \%$ & $12,0 \%$ & $0,0 \%$ & $0,0 \%$ & $0,0 \%$ & $20,0 \%$ & $0,0 \%$ & $4,0 \%$ & $0,0 \%$ & $8,0 \%$ & $8,0 \%$ & $8,0 \%$ \\
\hline ESS/IPS & $0,0 \%$ & $7,0 \%$ & $3,5 \%$ & $5,3 \%$ & $1,8 \%$ & $12,3 \%$ & $1,8 \%$ & $5,3 \%$ & $1,8 \%$ & $33,3 \%$ & $1,8 \%$ & $3,5 \%$ & $5,3 \%$ & $0,0 \%$ & $8,8 \%$ & $8,8 \%$ \\
\hline TOTAL IPS & $0,7 \%$ & $9,5 \%$ & $11,7 \%$ & $1,1 \%$ & $4,0 \%$ & $13,6 \%$ & $2,6 \%$ & $10,3 \%$ & $5,5 \%$ & $23,8 \%$ & $1,1 \%$ & $5,1 \%$ & $1,1 \%$ & $0,7 \%$ & $3,7 \%$ & $5,5 \%$ \\
\hline
\end{tabular}

\subsection{4 - Relação entre o emprego e a área de formação académica}

No que concerne à ligação existente entre a área de estudo e a atividade profissional desenvolvida pelos licenciados, verifica-se que 59,2\% trabalham numa atividade diretamente relacionada com a sua formação académica e 15,3\% encontram-se a desempenhar funções em áreas próximas ao 
curso que concluíram, sendo $25,5 \%$ os que não encontram correspondência entre a atividade desenvolvida e o diploma obtido.

Contudo, da análise por escola verifica-se que 94,9\% dos licenciados da ESS/IPS desempenham funções profissionais na área de formação académica, assim como os da ESCE/IPS $(58,5 \%)$ e da ESTS/IPS (57,8\%), onde mais de metade dos inquiridos trabalha em áreas diretamente relacionadas com a área de estudo. Por outro lado, é nos licenciados da ESE/IPS que menor correspondência se encontra, existindo cerca de $53,2 \%$ dos inquiridos a trabalhar em áreas completamente diferentes da formação académica obtida.

Quadro 7 - Relação entre a atividade profissional remunerada dos inquiridos licenciados do IPS e a área do curso
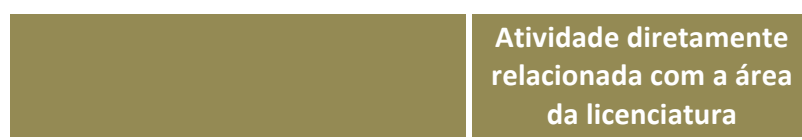

\section{ESTS/IPS}

$57,8 \%$

$17,5 \%$

$24,7 \%$

ESE/IPS

$37,1 \%$

$9,7 \%$

$53,2 \%$

ESCE/IPS

$58,5 \%$

$18,2 \%$

$23,3 \%$

ESTB/IPS

$47,2 \%$

$25,0 \%$

$27,8 \%$

ESS/IPS

$94,9 \%$

$3,4 \%$

$1,7 \%$

TOTAL IPS

$59,2 \%$

$15,3 \%$

$25,5 \%$

Fonte: Inquérito por questionário

\section{2. - Escola Superior de Tecnologia de Setúbal}

Na ESTS/IPS, a amostra é maioritariamente masculina, representando $71,1 \%$ do universo de inquiridos. Apenas nos cursos de Engenharia do Ambiente e Engenharia Biomédica a taxa de licenciados inquiridos do género feminino é superior (76,5\% e $68 \%$, respetivamente), conforme gráfico 8.

\section{Gráfico 8 - Distribuição dos inquiridos da ESTS/IPS por curso e género}

$$
\text { Masculino Feminino }
$$

\begin{tabular}{ccccccc}
$76,5 \%$ & $100,0 \%$ & $68,0 \%$ & $9,7 \%$ & $13,3 \%$ & $5,0 \%$ & $25,0 \%$ \\
$23,5 \%$ & $32,0 \%$ & $90,3 \%$ & $86,7 \%$ & $95,0 \%$ & $75,0 \%$ \\
\hline $\begin{array}{c}\text { Engenharia do } \\
\text { Ambiente }\end{array}$ & $\begin{array}{c}\text { Engenharia de } \\
\text { Automação, } \\
\text { Instrumentação } \\
\text { e Controlo }\end{array}$ & $\begin{array}{c}\text { Engenharia } \\
\text { Biomédica }\end{array}$ & $\begin{array}{c}\text { Engenharia } \\
\text { Eletrotécnica e } \\
\text { Computadores }\end{array}$ & $\begin{array}{c}\text { Engenharia } \\
\text { Informática }\end{array}$ & $\begin{array}{c}\text { Engenharia } \\
\text { Mecânica }\end{array}$ & $\begin{array}{c}\text { Tecnologia e } \\
\text { Gestão Industrial } \\
\text { (reg. noturno) }\end{array}$ \\
& & & &
\end{tabular}




\subsection{1 - Situação Profissional}

Relativamente à situação profissional dos licenciados verifica-se que $14,1 \%$ se encontra em situação de desemprego. Atualmente, $68,3 \%$ dos inquiridos estão empregados, 9,9\% realizam um estágio profissional e 7,7\% estudam, neste momento, a tempo inteiro.

$\mathrm{Na}$ análise comparativa da situação profissional por género, conclui-se que são as mulheres que em maior número enfrentam o desemprego (34,1\% das mulheres estão desempregadas e 5,9\% dos homens estão desempregados). Por outro lado, são as mulheres que continuam a apostar, em maior número, na prossecução dos seus estudos a tempo inteiro (9,8\% mulheres e $6,9 \%$ homens), sendo entre as licenciadas em Engenharia Biomédica e em Engenharia Informática que se verifica a taxa mais elevada.

Contudo, as assimetrias existentes em termos de desemprego no feminino podem estar diretamente relacionadas com as opções das mesmas relativamente ao curso onde se diplomaram. Com efeito, conforme se pode verificar no quadro 8, é entre os diplomados do curso de Engenharia do Ambiente e Engenharia Biomédica que a taxa de desemprego se apresenta mais alta. É também nestes cursos que se encontra o maior número de mulheres diplomadas o que, de certa forma, poderá explicar este fenómeno.

Gráfico 9 - Situação profissional dos inquiridos licenciados da ESTS/IPS, por género

Homens $\square$ Mulheres

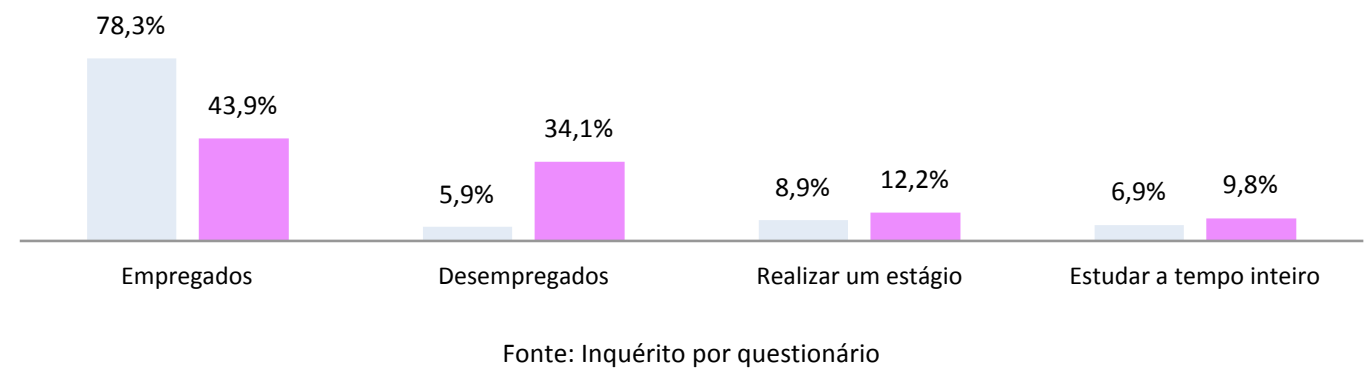

Relativamente aos índices de inserção profissional, por curso, denota-se que é a licenciatura em Engenharia de Automação, Instrumentação e Controlo que regista o valor mais alto, uma vez que a taxa de emprego se situa nos 100\%. Também os cursos de Engenharia Informática, Tecnologia e Gestão Industrial (regime noturno) e Eletrotécnica e Computadores apresentam taxas de emprego mais elevadas (90\%, 83,3\% e 80,6\%, respetivamente). Nos cursos de Engenharia do Ambiente e Engenharia Biomédica verificam-se taxas de emprego mais baixas. 
Quadro 8 - Situação profissional dos inquiridos licenciados da ESTS/IPS por curso

\begin{tabular}{|c|c|c|c|c|}
\hline & Empregado & Realizar estágio & Desempregado & $\begin{array}{c}\text { Estudar a } \\
\text { tempo inteiro }\end{array}$ \\
\hline Engenharia do Ambiente & $41,2 \%$ & $17,6 \%$ & $41,2 \%$ & $0,0 \%$ \\
\hline $\begin{array}{l}\text { Engenharia de Automação, } \\
\text { Instrumentação e Controlo }\end{array}$ & $100,0 \%$ & $0,0 \%$ & $0,0 \%$ & $0,0 \%$ \\
\hline Engenharia Biomédica & $36,0 \%$ & $8,0 \%$ & $28,0 \%$ & $28,0 \%$ \\
\hline $\begin{array}{l}\text { Engenharia Eletrotécnica e } \\
\text { Computadores }\end{array}$ & $80,6 \%$ & $9,7 \%$ & $6,5 \%$ & $3,2 \%$ \\
\hline Engenharia Informática & $90,0 \%$ & $3,3 \%$ & $0,0 \%$ & $6,7 \%$ \\
\hline Engenharia Mecânica & $60,0 \%$ & $25,0 \%$ & $10,0 \%$ & $5,0 \%$ \\
\hline $\begin{array}{l}\text { Tecnologia e Gestão Industrial (regime } \\
\text { noturno) }\end{array}$ & $83,3 \%$ & $0,0 \%$ & $16,7 \%$ & $0,0 \%$ \\
\hline TOT A L ESTS/IPS & $68,3 \%$ & $9,9 \%$ & $14,1 \%$ & $7,7 \%$ \\
\hline
\end{tabular}

De referir ainda que, na maioria dos cursos de engenharia lecionados na ESTS/IPS se verificou uma evolução muito positiva relativamente aos dados do desemprego disponibilizados pelo CCISP a 31 de Dezembro de 2011.

No que concerne à situação na profissão conclui-se que $95,9 \%$ dos inquiridos empregados trabalham por conta de outrem, sendo apenas $3,1 \%$ os que trabalham por conta própria e $1 \%$ os que referem encontrar-se noutra situação.

Quadro 9 - Situação na profissão dos inquiridos licenciados da ESTS/IPS

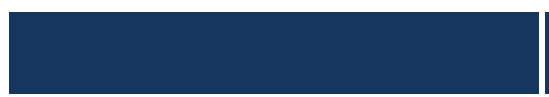

Trabalhador por

conta de outrem

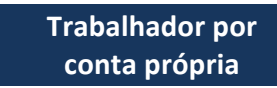

Engenharia do Ambiente

Engenharia de Automação, Instrumentação e Controlo

Engenharia Biomédica

Engenharia Eletrotécnica e

Computadores

Engenharia Informática

Engenharia Mecânica

Tecnologia e Gestão Industrial (regime noturno)

TOTAL ESTS/IPS
$85,7 \%$

conta própria

Outra Situação

$14,3 \%$

\begin{tabular}{l|l|l}
\hline $100,0 \%$ & $0,0 \%$ & $0,0 \%$
\end{tabular}

$\begin{array}{lll}77,8 \% & 22,2 \% & 0,0 \%\end{array}$

\begin{tabular}{l|l|l}
\hline $100,0 \%$ & $0,0 \%$ & $0,0 \%$
\end{tabular}

$\begin{array}{lll}100,0 & 0,0 \% & 0,0 \%\end{array}$

\begin{tabular}{|l|l|l}
\hline $91,7 \%$ & $8,3 \%$ & $0,0 \%$ \\
\hline
\end{tabular}

$\begin{array}{lll}100,0 \% & 0,0 \% & 0,0 \%\end{array}$

\begin{tabular}{l|l|l}
\hline $95,9 \%$ & $3,1 \%$ & $1,0 \%$ \\
\hline
\end{tabular}

Fonte: Inquérito por questionário 
No que diz respeito ao vínculo laboral existente entre os inquiridos empregados e as respetivas entidades empregadoras conclui-se que $61,9 \%$ possuem um contrato de trabalho sem termo, sendo $35,1 \%$ os que possuem um contrato de trabalho a prazo.

Em particular, é nos cursos de Tecnologia e Gestão Industrial (regime noturno), Engenharia Informática e Engenharia Eletrotécnica e Computadores que se verifica uma maior estabilidade contratual tendo em conta que, o contrato de trabalho por tempo indeterminado é mantido por mais de $50 \%$ desta população ( $100 \%, 77,8 \%$ e $68 \%$, respetivamente).

Por outro lado, os cursos de Engenharia do Ambiente, Engenharia Biomédica e Engenharia Mecânica são os que apresentam maior precaridade em termos de vínculo laboral e uma maior diversificação nas relações de trabalhos existentes.

Gráfico 10 - Vínculo laboral, por curso, dos inquiridos licenciados da ESTS/IPS

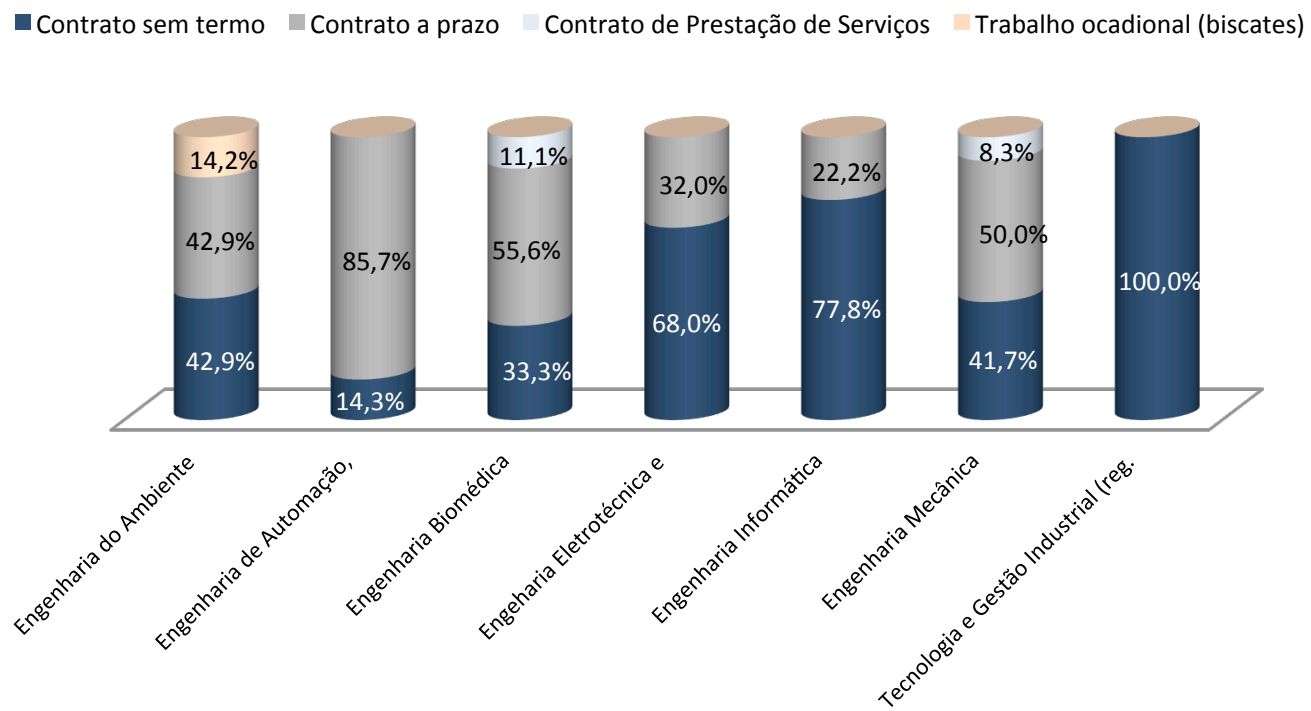

Fonte: Inquérito por questionário

No que concerne ao horário de trabalho, o emprego a tempo inteiro é praticado pela grande maioria dos inquiridos empregados $(90,7 \%)$ sendo que, apenas $9,3 \%$ trabalham a tempo parcial.

São, sobretudo, os licenciados do curso de Engenharia do Ambiente e Engenharia Biomédica que praticam o horário a tempo parcial, o que de certa forma, poderá ser a resposta para a precariedade do vínculo contratual detido por alguns destes licenciados, como podemos verificar no gráfico supra. Entre os licenciados em Engenharia de Automação, Instrumentação e Controlo e em Tecnologia e Gestão Industrial (regime noturno) o tempo de trabalho predominante é a tempo inteiro. 
Gráfico 11 - Duração do tempo de trabalho, por curso, dos inquiridos licenciados da ESTS/IPS

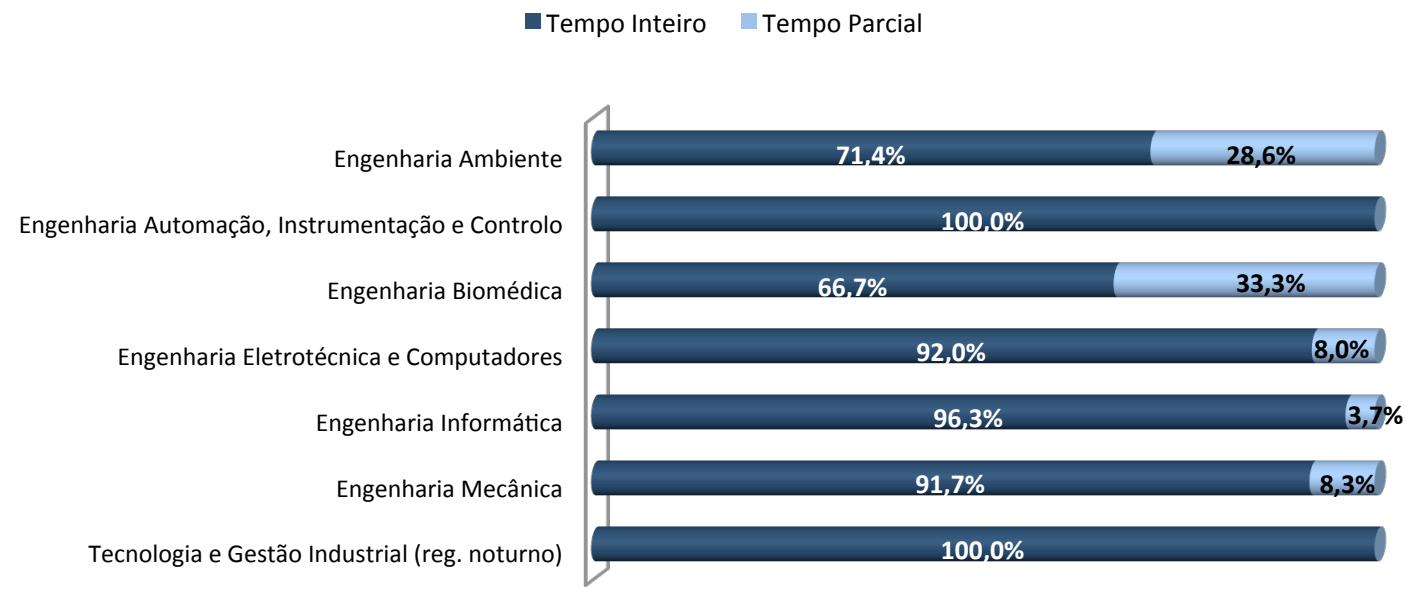

Fonte: Inquérito por questionário

\subsection{2 - Tipo de empresa/organização, localização geográfica e nível de remuneração}

O setor privado emprega cerca de $83,6 \%$ dos licenciados nos cursos da ESTS/IPS. Com efeito, apenas $16,5 \%$ dos inquiridos trabalha em organismos públicos. No entanto, de entre as empresas privadas são as pequenas e médias empresas que mais licenciados engenheiros empregam (47,3\%). Verifica-se também, que $36,3 \%$ dos inquiridos se encontram inseridos em empresas de média e grande dimensão (com mais de 99 empregados).

Gráfico 12 - Tipo de empresa/organização onde trabalham os inquiridos licenciados da ESTS/IPS

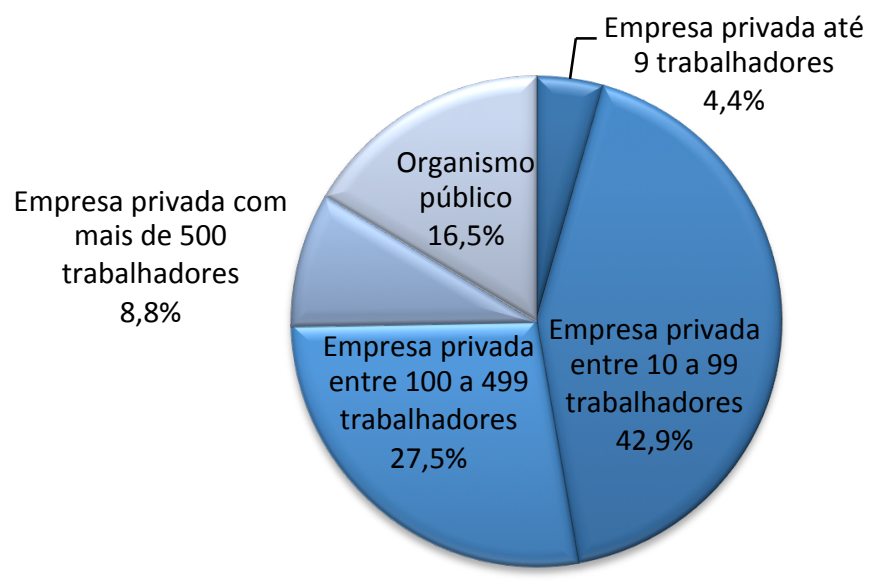

Fonte: Inquérito por questionário

Conforme se verifica no quadro infra, as empresas do sector privado (entre 10 a 99 empregados) são as que tendem a absorver maioritariamente os licenciados em Engenharia Mecânica, Engenharia Informática e em Engenharia Eletrotécnica e Computadores (58,3\%, 52\% e 50\% 
respetivamente). Na Administração Pública existem, sobretudo, licenciados nos cursos de Engenharia Biomédica (28,6\%) e Engenharia Informática (28\%), com exceção dos licenciados em Engenharia de Automação, Instrumentação e Controlo e em Engenharia Mecânica que não fazem parte do universo deste tipo de empresa.

As empresas privadas com mais de 99 trabalhadores são as principais empregadoras de licenciados em Engenharia de Automação, Instrumentação e Controlo $(85,7 \%)$ sendo que, também os licenciados em Engenharia do Ambiente (66,6\%) fazem parte do universo destas empresas.

Quadro 10 - Dimensão da empresa/organização, por curso, onde trabalham os inquiridos licenciados da ESTS/IPS
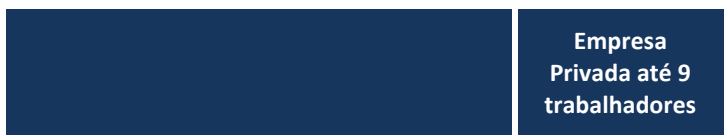

Empresa
Privada entre
10 a 99
trabalhadores

Empresa
Privada entre
100 a 499

Empresa

Privada com

mais de $\mathbf{5 0 0}$

trabalhadores

trabalhadores

trabalhadores

Organismos

Públicos

\begin{tabular}{|c|c|c|c|c|c|}
\hline Engenharia do Ambiente & $0,0 \%$ & $16,7 \%$ & $33,3 \%$ & $33,3 \%$ & $16,7 \%$ \\
\hline $\begin{array}{l}\text { Engenharia de Automação, } \\
\text { Instrumentação e Controlo }\end{array}$ & $0,0 \%$ & $14,3 \%$ & $85,7 \%$ & $0,0 \%$ & $0,0 \%$ \\
\hline Engenharia Biomédica & $14,3 \%$ & $28,6 \%$ & $28,6 \%$ & $0,0 \%$ & $28,6 \%$ \\
\hline $\begin{array}{l}\text { Engenharia Eletrotécnica e } \\
\text { Computadores }\end{array}$ & $12,5 \%$ & $50,0 \%$ & $16,7 \%$ & $8,3 \%$ & $12,5 \%$ \\
\hline Engenharia Informática & $0,0 \%$ & $52,0 \%$ & $20,0 \%$ & $0,0 \%$ & $28,0 \%$ \\
\hline Engenharia Mecânica & $0,0 \%$ & $58,3 \%$ & $33,3 \%$ & $8,3 \%$ & $0,0 \%$ \\
\hline $\begin{array}{l}\text { Tecnologia e Gestão Industrial } \\
\text { (regime noturno) }\end{array}$ & $0,0 \%$ & $30,0 \%$ & $20,0 \%$ & $30,0 \%$ & $20,0 \%$ \\
\hline TOTAL ESTS/IPS & $4,4 \%$ & $42,9 \%$ & $27,5 \%$ & $8,8 \%$ & $16,5 \%$ \\
\hline
\end{tabular}

Fonte: Inquérito por questionário

No que se refere ao setor de atividade, os licenciados empregados distribuem-se essencialmente pelos setores da indústria transformadora, eletricidade, água e gás e construção de obras públicas $(28,6 \%)$, dos serviços prestados às empresas $(23,1 \%)$, transportes e comunicações $(12,1 \%)$, comércio $(9,9 \%)$, administração pública central $(5,5 \%)$, saúde e ação social $(4,4 \%)$, administração pública local $(3,3 \%)$, educação $(2,2 \%)$ existindo, ainda, $11 \%$ dos inquiridos que apontam outros setores não identificados.

Relativamente à localização geográfica das entidades empregadoras, Setúbal e Lisboa são os concelhos mais apontados $(22,1 \%$ e $31,6 \%$, respetivamente). No entanto, conforme se pode 
constatar no gráfico abaixo, a maior concentração das empresas onde os inquiridos trabalham localizam-se no distrito de Setúbal (55,9\%). De referir, também, a existência de 1,1\% de licenciados que trabalham em empresas/organizações fora do país.

Gráfico 13 - Localização geográfica da empresa/organização onde trabalham os inquiridos licenciados da ESTS/IPS

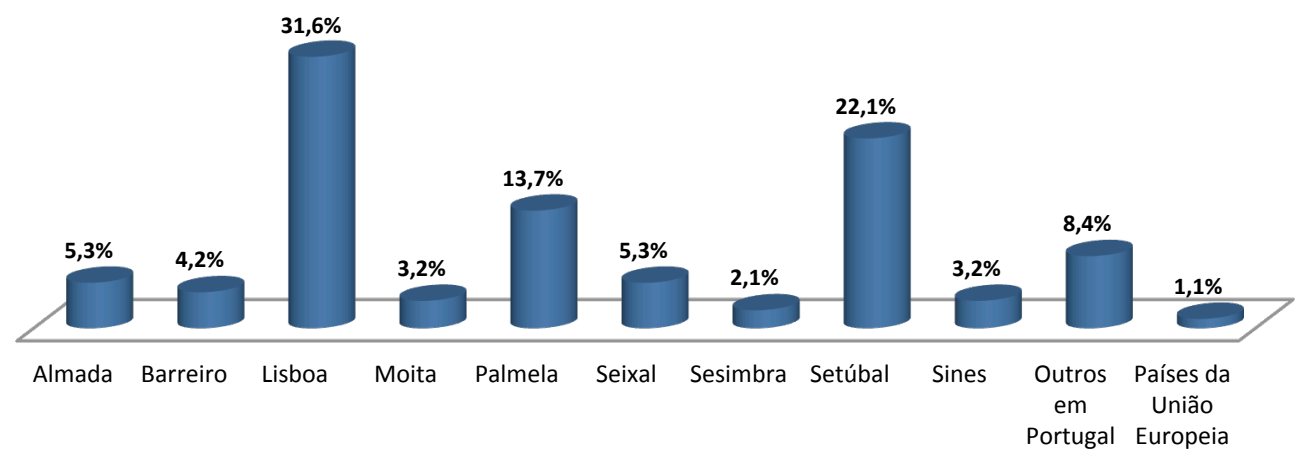

Fonte: Inquérito por questionário

Conforme se pode aferir no quadro infra, é no escalão remuneratório $751-1.000 €$ que se encontram inseridos grande parte dos licenciados empregados $(43,5 \%)$, logo seguido do escalão cujo valor remuneratório líquido mensal é superior a $1.250 €$ e que representa $19,5 \%$ dos inquiridos.

Assim, importa evidenciar que a maioria dos licenciados da ESTS/IPS aufere um salário líquido mensal acima dos $750 €(69,5 \%)$. Pouco expressiva é a taxa associada aos inquiridos que auferem menos de $251 €(2,2 \%)$, situação que parece estar associada à elevada percentagem de diplomados que trabalha a tempo inteiro.

Ao efetuar-se uma análise por curso percebe-se que são os licenciados em Tecnologia e Gestão Industrial (regime noturno) e em Engenharia de Automação, Instrumentação e Controlo que recebem, em média, o salário líquido mensal mais alto $(60,0 \%$ e $42,9 \%$, respetivamente, auferem mais de 1.250€). Os licenciados em Engenharia do Ambiente e Engenharia Biomédica não recebem um salário superior a $1.000 €$ encontrando-se, atualmente, $57,1 \%$ deste universo de diplomados, a auferir menos de $501 €$ líquidos mensais. 
Quadro 11 - Remuneração mensal líquida, por curso, dos inquiridos licenciados da ESTS/IPS

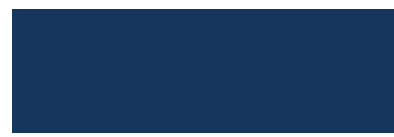

Engenharia do Ambiente

Engenharia de Automação, Instrumentação e Controlo

Engenharia Biomédica

Engenharia Eletrotécnica e Computadores

Engenharia Informática

Engenharia Mecânica

Tecnologia e Gestão Industrial (regime noturno)

TO T A L ESTS/IPS
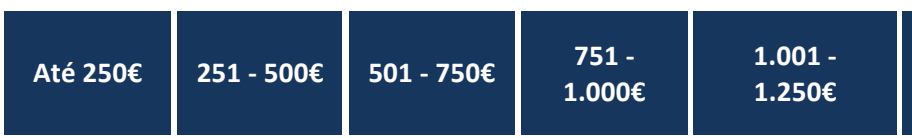

Mais de

$1.250 €$

\section{$14,2 \%$}

$28,6 \%$

$28,6 \%$

$28,6 \%$

$0,0 \%$

$0,0 \%$

$0,0 \%$

$0,0 \%$

$0,0 \%$

$57,1 \%$

$0,0 \%$

$42,9 \%$

$0,0 \% \quad 14,3 \%$

$57,1 \%$

$28,6 \%$

$0,0 \%$

$0,0 \%$

$0,0 \%$

$12,0 \%$

$24,0 \%$

$44,0 \%$

$4,0 \%$

$16,0 \%$

$4,2 \%$

$4,2 \%$

$12,5 \%$

$50,0 \%$

$12,5 \%$

$16,6 \%$

$0,0 \%$

$16,7 \%$

$8,3 \%$

$50,0 \%$

$16,7 \%$

$8,3 \%$

$0,0 \%$

$0,0 \%$

$10,0 \%$

$30,0 \%$

$0,0 \%$

$60,0 \%$

$2,2 \%$

$9,8 \%$

$18,5 \%$

$43,5 \%$

$6,5 \%$

$19,5 \%$

Fonte: Inquérito por questionário

\subsection{3 - Meios de acesso ao emprego}

O serviço de apoio à inserção profissional disponibilizado pela ESTS/IPS é identificado por 19,4\% dos inquiridos, como o principal potenciador da inserção dos mesmos na vida ativa. As candidaturas espontâneas (29\%), a resposta a anúncios em jornais e revistas $(16,1 \%)$ e o acesso privilegiado dos familiares dentro das organizações $(12,9 \%)$ foram outros meios de acesso ao emprego identificados pelos licenciados, destacando-se o papel do capital social no acesso ao emprego.

Gráfico 14 - Meios de acesso ao emprego, dos inquiridos licenciados da ESTS/IPS

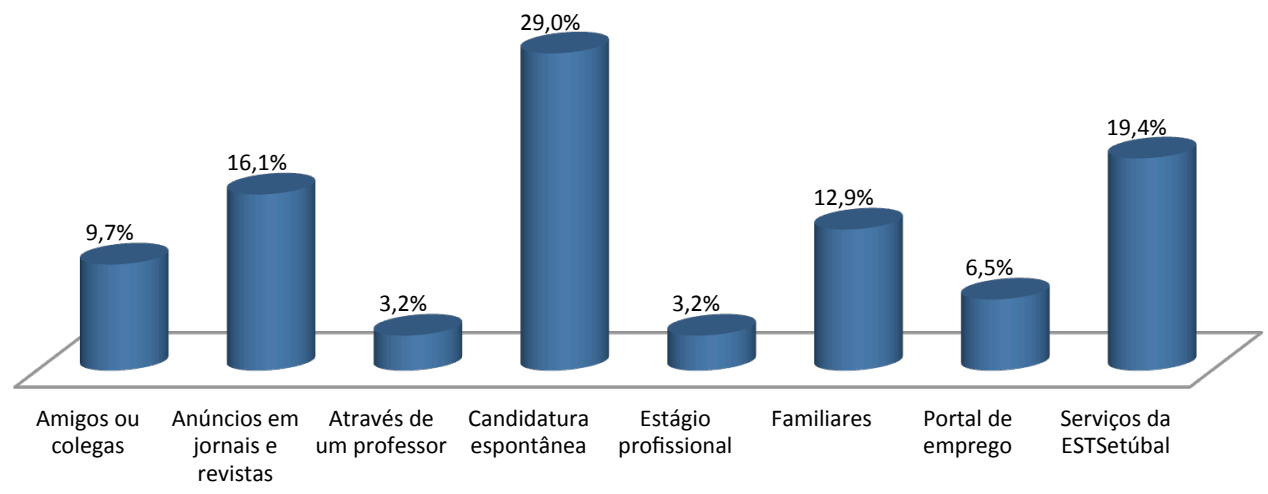




\subsection{4 - Relação entre o emprego e a área de formação académica}

Relativamente à ligação existente entre a área de estudo e a atividade profissional desenvolvida, verifica-se que $57,8 \%$ dos licenciados na ESTS/IPS trabalha numa atividade diretamente relacionada com a sua formação académica e 17,5\% encontram-se a desempenhar funções em áreas próximas ao curso de concluíram.

No entanto, a análise por curso evidencia resultados muito díspares. Os inquiridos, licenciados nos cursos de Engenharia em Informática, Engenharia em Automação, Instrumentação e Controlo e Engenharia Eletrotécnica e Computadores trabalham, na sua maioria, em funções diretamente relacionadas com a área de estudo $(77,8 \%, 100 \%$ e $64 \%$, respetivamente) mas, os licenciados em Engenharia do Ambiente e Engenharia Biomédica são os que menor correspondência encontram entre o emprego que detêm e a licenciatura em que se diplomaram.

Quadro 12 - Relação entre a atividade profissional remunerada dos inquiridos licenciados da ESTS/IPS e a área do curso
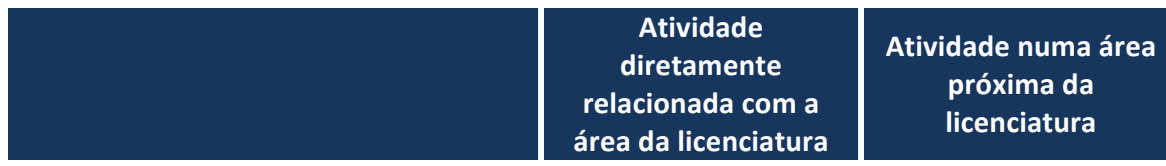

Engenharia do Ambiente

Engenharia de Automação, Instrumentação e Controlo

Engenharia Biomédica

Engenharia Eletrotécnica e

Computadores

Engenharia Informática

Engenharia Mecânica

Tecnologia e Gestão Industrial (regime noturno)

T O T A L ESTS/IPS
$28,6 \%$

$100,0 \%$

$22,2 \%$

$64,0 \%$

$77,8 \%$

$41,7 \%$

$30,0 \%$

$57,8 \%$ licenciatura

$0,0 \%$

$0,0 \%$

$0,0 \%$

$16,0 \%$

$14,8 \%$

$41,7 \%$

$40,0 \%$

$17,5 \%$
Atividade numa área

totalmente diferente

da área da

licenciatura

$0,0 \%$

$77,8 \%$

$20,0 \%$

$7,4 \%$

$16,6 \%$

$30,0 \%$

$24,7 \%$

Fonte: Inquérito por questionário

Relativamente às profissões dos licenciados em Engenharia do Ambiente, a de Técnico de Suporte Ambiental, Investigador de Qualidade de Ar e Engenheiro Ambiental são as mais apontadas existindo alguns inquiridos que, não trabalhando na área de estudo, desempenham funções de Técnico de call center ou Operador de Caixa de Supermercado. 
Os licenciados em Engenharia da Automação, Instrumentação e Controlo, sendo os que maior correspondência encontram entre o diploma que possuem e as funções que executam, afirmam trabalhar como Engenheiros de Programação de Robots, Engenheiros de Processos e Controlo e Instrumentistas.

Entre os licenciados em Engenharia Biomédica as profissões mais apontadas são as de Técnico Comercial, Formador, Administrativo.

Os inquiridos do curso de Engenharia Eletrotécnica e Computadores exercem, essencialmente, funções de Engenheiros Eletrotécnicos, Engenheiros de Telecomunicações, Eletricistas e Docentes.

No que diz respeito às atividades profissionais, os licenciados em Engenharia Informática indicam desenvolver funções de Técnico/Especialista de Informática, existindo ainda alguns inquiridos que executam funções de Consultor Informático, Programador e Administrador de Sistemas. Fora da área de formação, a área comercial, como Técnicos de Vendas, é outra atividade apontada pelos inquiridos.

As profissões exercidas pelos licenciados em Engenharia Mecânica são essencialmente as de Engenheiro Mecânico, Operário Fabril, Orçamentista, Formador, Projetista de Cunhos e Cortantes e Técnico Comercial.

Por fim, os licenciados em Tecnologia e Gestão Industrial (regime noturno) indicam as atividades relacionadas com a Programação de Robots, Técnico de Manutenção, Técnico de Sistemas de Qualidade como as que desenvolvem. Contudo, alguns inquiridos referem que a sua profissão é a de Bibliotecário e Segurança.

\section{3 - Escola Superior de Educação}

Em termos gerais, verifica-se que a composição da amostra, entre os licenciados na ESE/IPS é, maioritariamente feminina uma vez que representa cerca de $79 \%$ dos inquiridos. Como podemos observar no gráfico 15 apenas o curso de Desporto apresenta uma taxa superior de inquiridos do sexo masculino ( $80 \%$ ) sendo que em todos os outros cursos o género feminino compõe quase a totalidade da amostra em estudo.

Gráfico 15 - Distribuição dos inquiridos licenciados da ESE/IPS por curso e género 


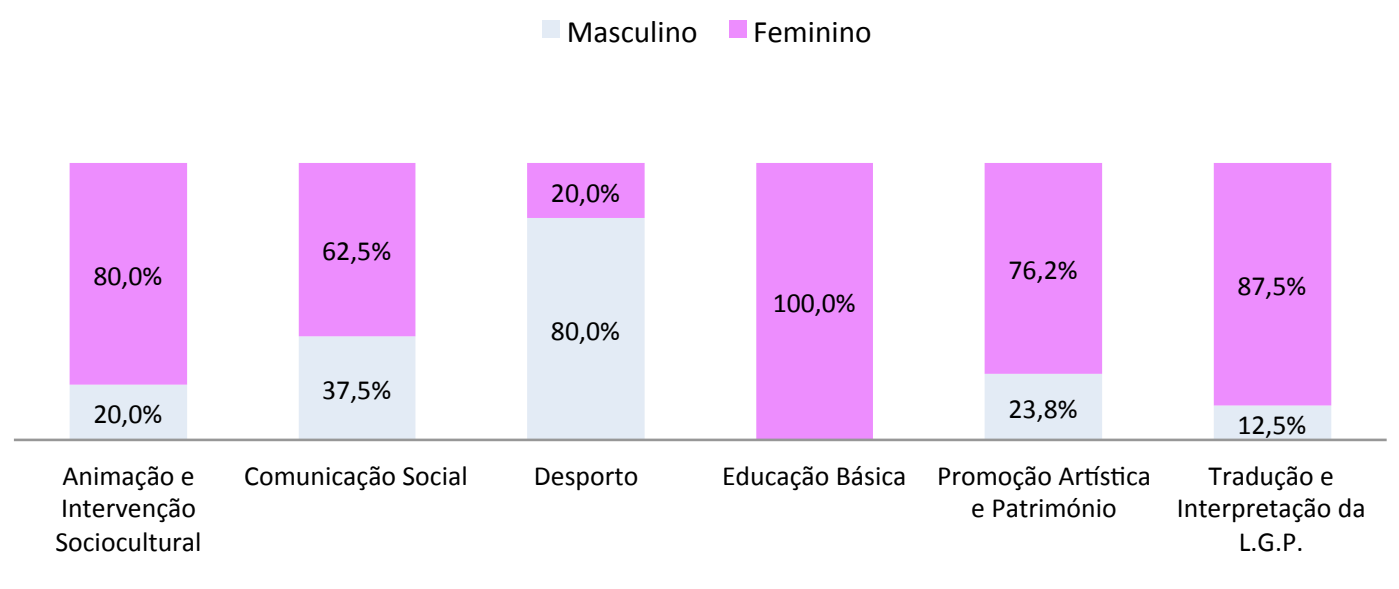

Fonte: Inquérito por questionário

\subsection{1 - Situação Profissional}

No que diz respeito à situação profissional dos licenciados conclui-se que, 52\% dos inquiridos se encontram empregados estando, em situação de desemprego, cerca de um quarto da amostra (26\%). Importa referir, que aproximadamente $18 \%$ dos licenciados em análise se encontram a estudar a tempo inteiro prosseguindo, assim, os seus estudos ao nível do mestrado. Esta situação é particularmente evidente na licenciatura em Educação Básica, já que a conclusão do Mestrado é condição necessária para o desempenho da profissão de docente do ensino básico.

Quando se compara a situação profissional com o género verifica-se que, apesar da existência de diferenças relativamente às taxas de emprego (61,5\% dos homens estão empregados, $49 \%$ das mulheres estão empregadas) é na taxa de desemprego que existe algum equilíbrio uma vez que, o desemprego entre os inquiridos do género masculino se encontra ligeiramente acima do das mulheres ( $27 \%$ e $25,5 \%$, respetivamente). Contudo, é na opção em estudar a tempo inteiro que se encontram algumas assimetrias tendo em conta que são as mulheres que claramente apostam na prossecução dos seus estudos a tempo inteiro ( $20,4 \%$ das mulheres, $7,7 \%$ dos homens) o que, de certa forma, poderá explicar as taxas de emprego apresentadas. 
Gráfico 16 - Situação profissional dos inquiridos licenciados da ESE/IPS por género

Homens Mulheres

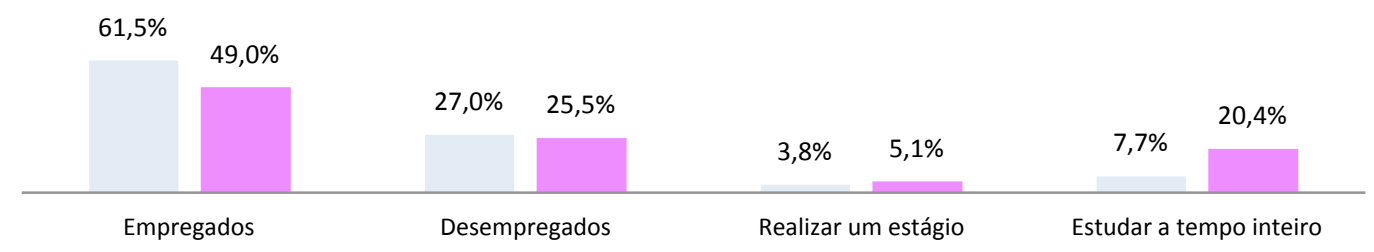

Fonte: Inquérito por questionário

Tratando-se, a situação profissional, o primeiro indicador da inserção destes licenciados no mercado de trabalho pode afirmar-se que, é no curso de Tradução e Interpretação da Língua Gestual Portuguesa que os índices de empregabilidade (cerca de $88 \%$ empregados) apresentam valores mais favoráveis. Por outro lado, pese embora no curso de Educação Básica apenas $53 \%$ dos inquiridos se encontrem inseridos na vida ativa, 44\% optaram por estudar a tempo inteiro inscrevendo-se em cursos de mestrado que lhes habilita para a docência, estando cerca de $17 \%$ em situação de desemprego.

Valores superiores, ao nível do desemprego, situam-se nos cursos de Comunicação Social e Promoção Artística e Património que, não obstante apresentarem taxas de emprego superiores a $50 \%$, o desemprego se situa nos $38 \%$ e a aposta num novo percurso académico a tempo inteiro é praticamente nula.

A realização de um estágio é a realidade profissional de cerca de $5 \%$ dos inquiridos, sendo apenas os licenciados em Educação Básica, Comunicação Social e Animação e Intervenção Sociocultural que se encontram nesta situação.

Quadro 13 - Situação profissional dos inquiridos licenciados da ESE/IPS por curso

\begin{tabular}{|c|c|c|c|c|}
\hline & Empregado & Realizar estágio & Desempregado & $\begin{array}{l}\text { Estudar a tempo } \\
\text { inteiro }\end{array}$ \\
\hline $\begin{array}{l}\text { Animação e Intervenção } \\
\text { Sociocultural }\end{array}$ & $66,6 \%$ & $13,4 \%$ & $20,0 \%$ & $0,0 \%$ \\
\hline Comunicação Social & $54,2 \%$ & $4,2 \%$ & $37,5 \%$ & $4,1 \%$ \\
\hline Desporto & $60,0 \%$ & $0,0 \%$ & $30,0 \%$ & $10,0 \%$ \\
\hline Educação Básica & $32,6 \%$ & $6,5 \%$ & $17,4 \%$ & $43,5 \%$ \\
\hline Promoção Artística e Património & $61,9 \%$ & $0,0 \%$ & $38,1 \%$ & $0,0 \%$ \\
\hline Tradução e Interpretação da L.G.P. & $87,5 \%$ & $0,0 \%$ & $12,5 \%$ & $0,0 \%$ \\
\hline TOT A L ESE/IPS & $51,6 \%$ & $4,8 \%$ & $25,8 \%$ & $17,8 \%$ \\
\hline
\end{tabular}

Fonte: Inquérito por questionário 
$\mathrm{Na}$ comparação com os dados disponibilizados pelo CCISP relativamente às taxas de desemprego em Dezembro de 2011, verifica-se a existência de alguma evolução (a taxa de desemprego apresentada pelo CCISP diz respeito aos diplomados licenciados no período de 2007/2008 a 2009/2010, em dezembro de 2011). De entre os cursos oferecidos na ESE/IPS, a licenciatura em Desporto apresentava a taxa de desemprego mais baixa (período de 2007/2008 a 2009/2010) denotando-se, atualmente, uma evolução menos favorável em termos de desemprego tendo em conta que, no momento em que os licenciados foram inquiridos, apenas $60 \%$ se encontravam empregados. Contudo, o horizonte temporal deste trabalho é de um ano, enquanto os dados dos licenciados inscritos nos centros de emprego se referem a um triénio. A licenciatura em TILGP apresentava-se como um dos cursos com maior índice de desemprego, segundo os dados do CCISP em Dezembro de 2011 e, revela agora, a taxa de emprego mais alta (88\%) entre o universo de estudantes em análise.

No que diz respeito à situação na profissão constata-se que $84 \%$ dos inquiridos empregados trabalham por conta de outrem. São $11 \%$ os inquiridos que indicam trabalhar por conta própria como trabalhadores independentes.

Quadro 14 - Situação na profissão dos inquiridos licenciados da ESE/IPS por curso

\begin{tabular}{|c|c|c|c|}
\hline & $\begin{array}{l}\text { Trabalhador por } \\
\text { conta de outrem }\end{array}$ & $\begin{array}{l}\text { Trabalhador por } \\
\text { conta própria }\end{array}$ & Outra Situação \\
\hline Animação e Intervenção Sociocultural & $80,0 \%$ & $10,0 \%$ & $10,0 \%$ \\
\hline Comunicação Social & $84,6 \%$ & $15,4 \%$ & $0,0 \%$ \\
\hline Desporto & $83,3 \%$ & $16,7 \%$ & $0,0 \%$ \\
\hline Educação Básica & $73,3 \%$ & $20,0 \%$ & $6,7 \%$ \\
\hline Promoção Artística e Património & $92,3 \%$ & $0,0 \%$ & $7,7 \%$ \\
\hline $\begin{array}{l}\text { Tradução e Interpretação da Língua } \\
\text { Gestual Portuguesa }\end{array}$ & $100 \%$ & $0,0 \%$ & $0,0 \%$ \\
\hline TO T A L ESE/IPS & $84,4 \%$ & $10,9 \%$ & $4,7 \%$ \\
\hline
\end{tabular}

Relativamente ao vínculo laboral mantido com as entidades empregadoras, 53,9\% dos inquiridos afirmam possuir um contrato de trabalho com termo, sendo 28,6 \% os que detêm um contrato de trabalho por tempo indeterminado. Da análise por curso conclui-se, que são sobretudo os licenciados em Comunicação Social e Tradução e Interpretação da Língua Gestual Portuguesa que apresentam uma relação de trabalho baseada no contrato de trabalho com termo $(76,9 \%$ e $100 \%$, respetivamente), sendo na licenciatura em Educação Básica e Animação e Intervenção Sociocultural que se verifica uma maior diversificação nas relações de trabalho existentes. 
Contudo, conforme podemos aferir no gráfico infra, é nos cursos de Comunicação Social, Desporto e Educação Básica que se encontra uma maior precariedade em termos de vínculo laboral uma vez que cerca de $15 \%, 33 \%$ e $20 \%$, respetivamente, possuem um contrato de prestação de serviços.

Gráfico 17 - Vínculo laboral, por curso, dos inquiridos licenciados da ESE/IPS

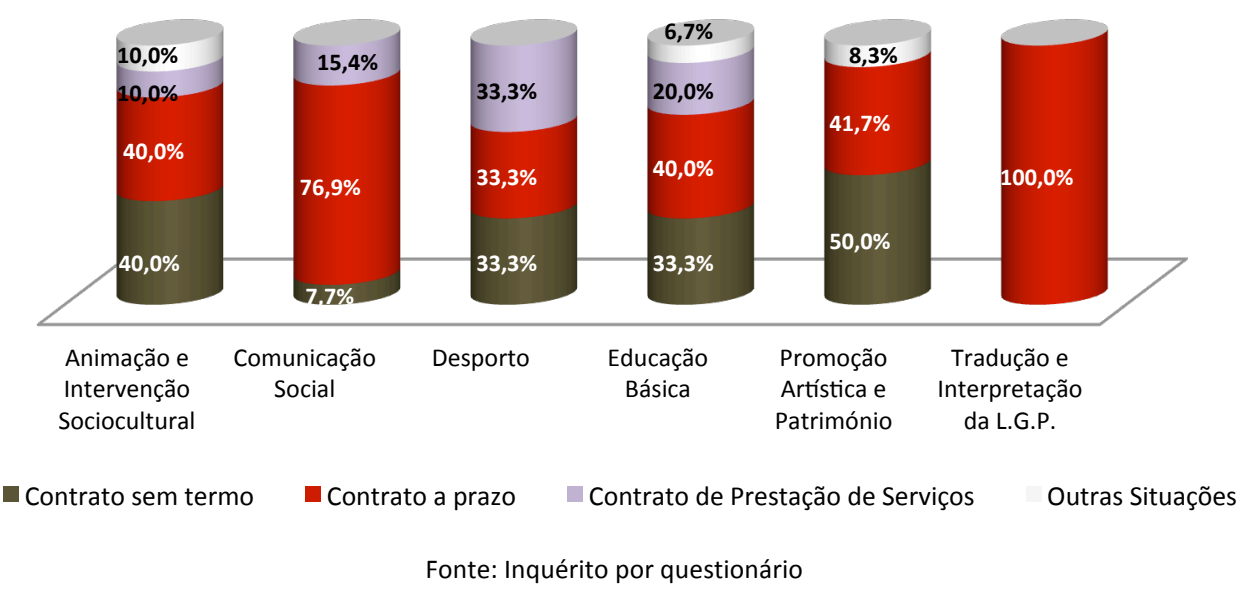

No que concerne ao horário de trabalho, o emprego a tempo parcial surge apenas para $22,2 \%$ do universo dos licenciados empregados sendo que $77,8 \%$ exercem a sua atividade profissional a tempo inteiro.

No curso de Desporto verifica-se uma distribuição equitativa dos licenciados empregados pelos dois tipos de tempos de trabalho e entre os licenciados em Animação e Intervenção Sociocultural o tempo de trabalho predominante é a tempo inteiro.

Gráfico 18 - Duração do tempo de trabalho, por curso, dos inquiridos licenciados da ESE/IPS

$$
\text { - Tempo Inteiro Tempo Parcial }
$$

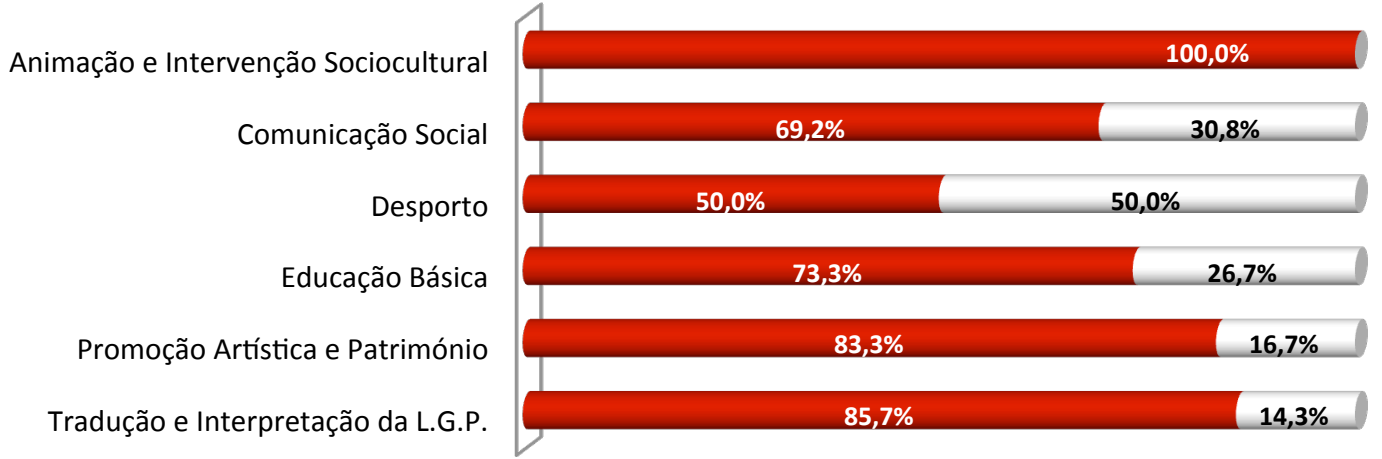




\subsection{2 - Tipo de empresa/organização, localização geográfica e nível de remuneração}

Relativamente às empresas empregadoras verifica-se, em termos gerais, que são nas do setor privado que se encontram a maioria dos licenciados empregados (69,3\%). A Administração Pública absorve cerca de $22,6 \%$ dos inquiridos, sendo as autarquias as principais empregadoras neste setor.

No setor privado, as pequenas e médias empresas são as responsáveis pela inserção profissional dos licenciados na ESE. Com efeito, dos inquiridos que trabalham em empresas privadas, cerca $70 \%$ desempenha a sua atividade profissional em empresas até 99 trabalhadores.

Gráfico 19 - Tipo de empresa/organização onde trabalham os inquiridos licenciados da ESE/IPS

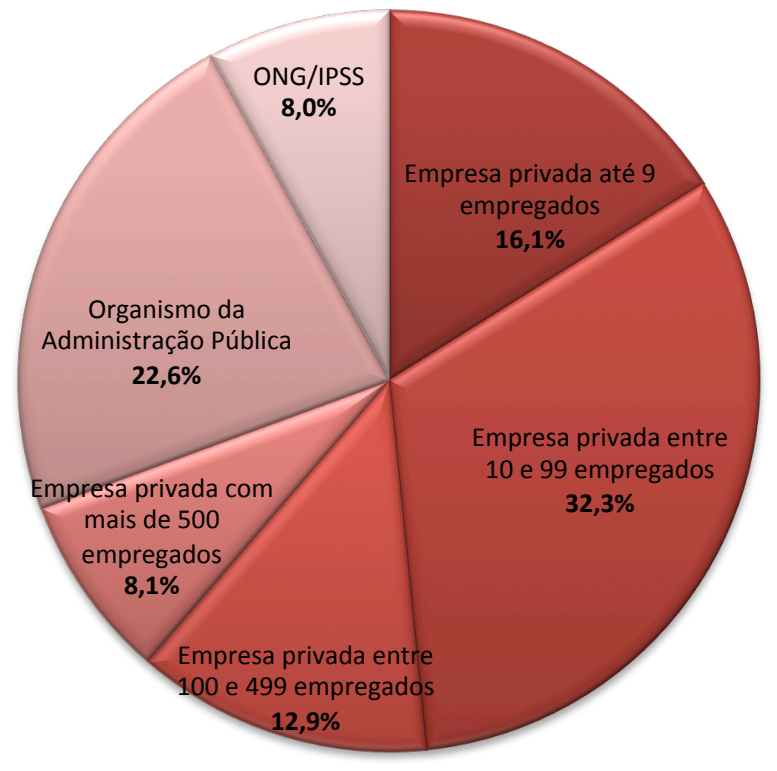

Fonte: Inquérito por questionário

Por sua vez, conforme se pode verificar no quadro infra, a área de Animação e Intervenção Sociocultural tende a ser absorvida maioritariamente pelas ONG/IPSS (40\%) e pelo setor público (30\%). Verifica-se, ainda, uma distribuição uniforme entre o setor privado e público nos cursos de Desporto e Promoção Artística e Património (50\%). Por outro lado, os licenciados no curso de Comunicação Social e Tradução e Interpretação da Língua Gestual Portuguesa inseriram-se, no mercado de trabalho, unicamente em empresas do setor privado. A inserção dos licenciados em Educação Básica pressuponha-se ser maioritariamente no setor público no entanto, tal não se verifica uma vez que apenas o mestrado habilita estes diplomados para a docência. Assim, é no setor privado, em empresas com menos de 100 trabalhadores $(71,5 \%)$, que se concentram maioritariamente estes profissionais da educação. 
Quadro 15 - Dimensão da empresa/organização, por curso, onde trabalham os inquiridos licenciados da ESE/IPS

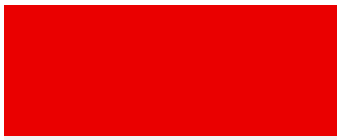

Animação e Intervenção Sociocultural

Comunicação Social

Desporto

Educação Básica

Promoção Artística e

Património

Tradução e Interpretação

da L. G. P.

TO T A L ESE/IPS

Empresa
Privada até 9
trabalhadores

$0,0 \%$

$38,5 \%$

$33,3 \%$

$14,3 \%$

$8,3 \%$

$0,0 \%$

$16,1 \%$

Empresa
Privada entre
10 a 99
trabalhadores

$20,0 \%$

$20,0 \%$

$30,8 \%$

$16,7 \%$

$57,2 \%$

$16,7 \%$

$42,8 \%$

$32,3 \%$

Empresa
Privada entre
100 a 499
trabalhadores

Empresa

Privada com

mais de $\mathbf{5 0 0}$

trabalhadores

$10,0 \%$

$23,1 \%$

$0,0 \%$

$16,7 \%$

$28,6 \%$

$12,9 \%$

Fonte: Inquérito por questionário
$0,0 \%$

$7,6 \%$

$0,0 \%$

$7,1 \%$

Organismos
Públicos

$30,0 \%$

$0,0 \%$

$50 \%$

$14,3 \%$

$50 \%$

$0,0 \%$

$22,6 \%$

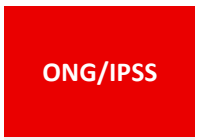

$40,0 \%$

$0,0 \%$

$0,0 \%$

$7,1 \%$

$0,0 \%$

$28,6 \%$

$8,1 \%$

$0,0 \%$

$8,0 \%$ 
Relativamente ao vencimento líquido mensal auferido pelos licenciados empregados verifica-se que é no escalão de rendimento 501 - $750 €$ que se situam cerca de $43,1 \%$ dos inquiridos. No escalão mais baixo, até $250 €$, inserem-se apenas $6,9 \%$, grande parte decorrente do trabalho a tempo parcial existente.

Da análise por curso, conclui-se que os licenciados em Educação Básica (61,5\%), Tradução e Interpretação da Língua Gestual Portuguesa $(57,1 \%)$, Comunicação Social $(46,2 \%)$ se situam essencialmente no escalão de rendimento 501 - 750€. São os licenciados em Animação e Intervenção Sociocultural (40\%), Desporto (20\%) e Promoção Artística e Património (40\%) que auferem, em maior número, um salário compreendido entre os 751 - 1.000€, sendo que apenas os inquiridos do curso de Desporto (20\%) têm uma remuneração acima dos $1.000 €$.

Quadro 16 - Remuneração mensal líquida dos licenciados da ESE/IPS por curso

\begin{tabular}{|c|c|c|c|c|c|}
\hline & Até $250 €$ & $251-500 €$ & $501-750 €$ & $751-1.000 €$ & $1.001-1.250 €$ \\
\hline $\begin{array}{l}\text { Animação e Intervenção } \\
\text { Sociocultural }\end{array}$ & $0,0 \%$ & $30,0 \%$ & $30,0 \%$ & $40,0 \%$ & $0,0 \%$ \\
\hline Comunicação Social & $23,1 \%$ & $30,8 \%$ & $46,2 \%$ & $0,0 \%$ & $0,0 \%$ \\
\hline Desporto & $0,0 \%$ & $40,0 \%$ & $20,0 \%$ & $20,0 \%$ & $20,0 \%$ \\
\hline Educação Básica & $0,0 \%$ & $30,8 \%$ & $61,5 \%$ & $7,7 \%$ & $0,0 \%$ \\
\hline $\begin{array}{l}\text { Promoção Artística e } \\
\text { Património }\end{array}$ & $0,0 \%$ & $30,0 \%$ & $30,0 \%$ & $40,0 \%$ & $0,0 \%$ \\
\hline $\begin{array}{l}\text { Tradução e Interpretação } \\
\text { da L. G. P. }\end{array}$ & $14,3 \%$ & $28,6 \%$ & $57,1 \%$ & $0,0 \%$ & $0,0 \%$ \\
\hline TOTAL ESE/IPS & $6,9 \%$ & $31,0 \%$ & $43,1 \%$ & $17,2 \%$ & $1,7 \%$ \\
\hline
\end{tabular}

\subsection{3 - Meios de acesso ao emprego}

Muitos são os fatores que determinam os meios utilizados na procura de emprego. Para Marques (2007), a origem social dos licenciados está relacionada com os mecanismos que os mesmos adotam para se inserirem no mercado de trabalho, sendo a rede de amigos e familiares um dos meios privilegiados para o acesso ao emprego.

Entre os licenciados da ESE/IPS, a entrada no mundo do trabalho através de amigos, conhecidos ou colegas apresenta-se como a segunda opção mais indicada entre os inquiridos empregados (17\%). A candidatura espontânea é, efetivamente, o meio mais utilizado $(36,2 \%)$ por estes diplomados sendo a entrada na vida ativa através do estágio curricular, familiares e portal de emprego os que menos representatividade apresentam $(2,1 \%)$. 
Gráfico 21 - Meios de acesso ao emprego, dos inquiridos licenciados da ESE/IPS

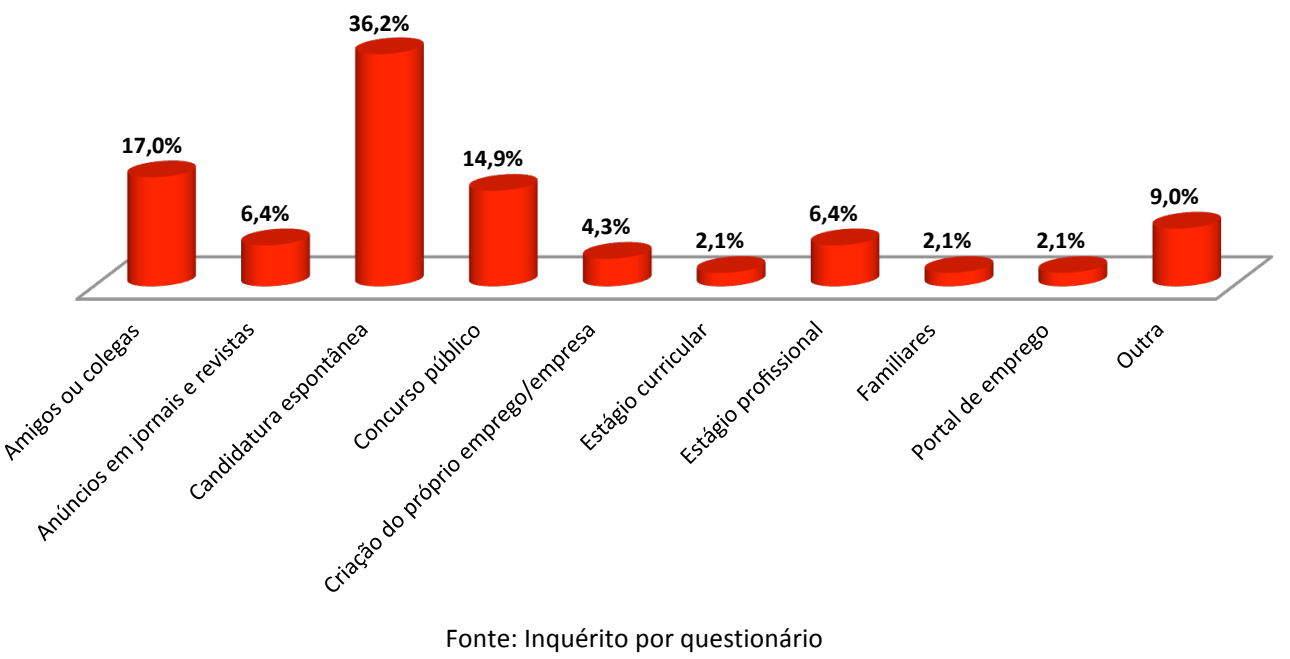

\subsection{4 - Relação entre o emprego e a área de formação académica}

Relativamente a esta dimensão da integração profissional constata-se que apenas $37,1 \%$ dos diplomados se encontram a desempenhar funções diretamente relacionadas com o curso que concluíram, estando 53,2\% a trabalhar em áreas completamente distintas.

Por outro lado, da análise por curso conclui-se que existem diferenças substanciais entre áreas de formação. Com efeito, 83,3\% dos licenciados em Desporto trabalham numa atividade diretamente ligada à formação académica que obtiveram, sendo que nenhum dos inquiridos se encontra a desempenhar funções totalmente diferentes da área do curso. Também o curso de Animação e Intervenção Sociocultural apresenta resultados muito positivos quando se relacionam as atividades profissionais desenvolvidas com a formação académica, sendo que $80 \%$ dos inquiridos empregados trabalham em áreas diretamente relacionadas, ou muito próximas, da área de formação.

São, no entanto, os licenciados em Tradução e Interpretação da Língua Gestual Portuguesa, Promoção Artística e Património e Comunicação Social que menor correspondência encontram entre o emprego que detêm e a licenciatura em que se diplomaram. 
Quadro 17 - Relação entre a atividade profissional remunerada dos inquiridos licenciados da ESE/IPS e a área do curso

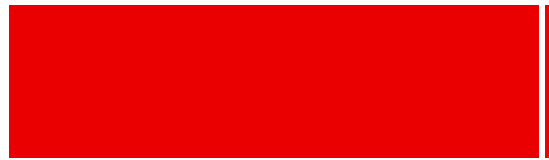

Animação e Intervenção Sociocultural Comunicação Social

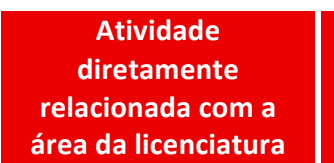

área da licenciatura
Atividade numa área próxima da licenciatura Atividade numa área totalmente diferente da área da licenciatura

\begin{tabular}{|c|c|c|c|}
\hline Animação e Intervenção Sociocultural & $70,0 \%$ & $10,0 \%$ & $20,0 \%$ \\
\hline Comunicação Social & $7,7 \%$ & $15,4 \%$ & $76,9 \%$ \\
\hline Desporto & $83,3 \%$ & $16,7 \%$ & $0,0 \%$ \\
\hline Educação Básica & $57,1 \%$ & $7,2 \%$ & $35,7 \%$ \\
\hline Promoção Artística e Património & $8,3 \%$ & $8,3 \%$ & $83,4 \%$ \\
\hline $\begin{array}{l}\text { Tradução e Interpretação da Língua } \\
\text { Gestual Portuguesa }\end{array}$ & $14,3 \%$ & $0,0 \%$ & $85,7 \%$ \\
\hline T O T A L ESE/IPS & $37,1 \%$ & $9,7 \%$ & $53,2 \%$ \\
\hline
\end{tabular}

Fonte: Inquérito por questionário

As funções desempenhadas pelos inquiridos empregados, em contexto de trabalho, são diversas. Os diplomados no curso de Animação e Intervenção Sociocultural indicam ter como profissão a Animação Cultural contudo, alguns deles referem ainda que desempenham funções administrativas, comerciais e operadores de call center. No curso de Comunicação Social, apesar de existirem alguns inquiridos a trabalhar como entrevistadores/jornalistas na sua maioria trabalham nas mais diversas áreas: operador de loja, operador de call center, técnico comercial, entre outros.

As profissões detidas pelos inquiridos do curso de Desporto são, sobretudo, de professores de educação física. Os licenciados em Educação Básica exercem essencialmente funções de Educadores de Infância e Auxiliares de Educação, existindo alguns que referem trabalhar em áreas comerciais.

Os inquiridos empregados com formação no curso de Promoção Artística e Património exercem funções na área da promoção artística e como técnicos de biblioteca e documentação, referindo ainda a área administrativa e comercial.

Por fim, o curso de Tradução e Interpretação da Língua Gestual Portuguesa que, apesar de apresentar indicadores muito favoráveis no que diz respeito à situação profissional (87,5\% estão empregados) apresenta muito pouca correspondência entre a profissão desempenhada e a área de curso. Com efeito, para além de tradutor, as profissões mais apontadas são as de operador de caixa de supermercado e de call center. 


\section{4 - Escola Superior de Ciências Empresariais}

Os licenciados respondentes da ESCE/IPS são, na sua maioria, do género feminino $(60,1 \%)$ verificando-se, no entanto, que nos cursos de Gestão da Distribuição e da Logística (regime pós laboral) e no curso de Gestão de Sistemas de Informação são os inquiridos do género masculino que apresentam as taxas mais elevadas (60\% e 54,5\%, respetivamente) não existindo, contudo, diferenças substanciais.

O curso de Gestão de Recursos Humanos (regime pós laboral) é o que apresenta maior assimetria no que respeita ao género, tendo em conta que o universo masculino representa apenas $25 \%$ da amostra.

Gráfico 22 - Distribuição dos inquiridos licenciados da ESCE/IPS por curso e género

Masculino Feminino

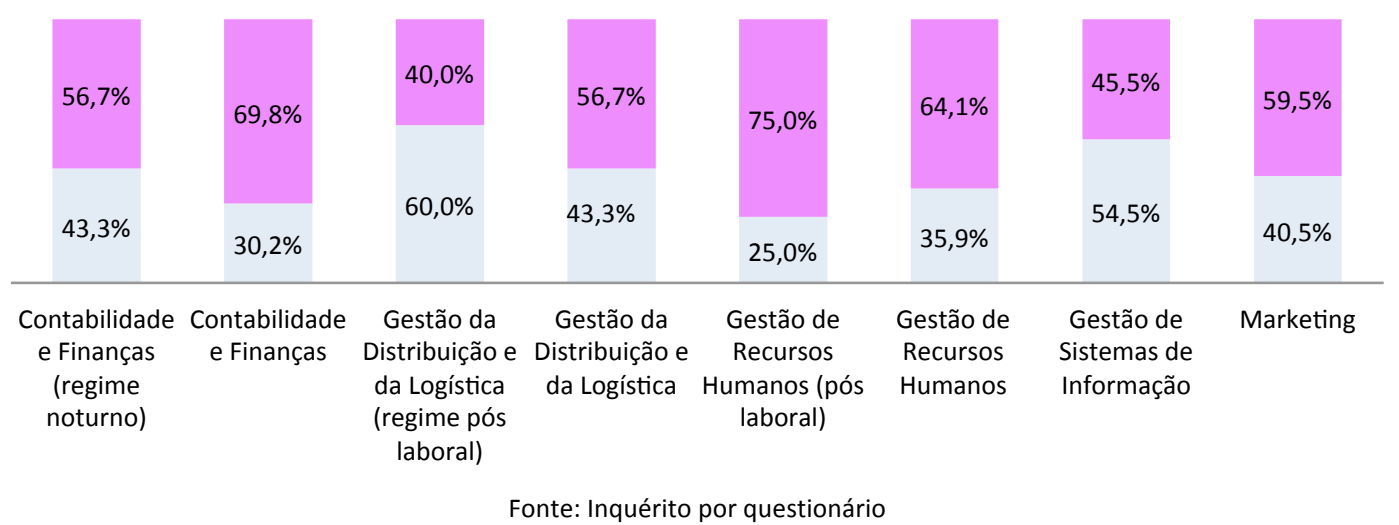

\subsection{1 - Situação Profissional}

Do universo de inquiridos, em análise, 15,2\% encontram-se em situação de desemprego. A diferença na taxa de desemprego entre géneros não é significativa tendo em conta que os inquiridos do sexo masculino apresentam uma taxa de $14,8 \%$ e as mulheres, $15,7 \%$. Por conseguinte, é a realizar estágio profissional que encontramos mais mulheres $(11,9 \%$ de mulheres e $5,7 \%$ de homens). 
Gráfico 23 - Situação profissional dos inquiridos licenciados da ESCE/IPS por género

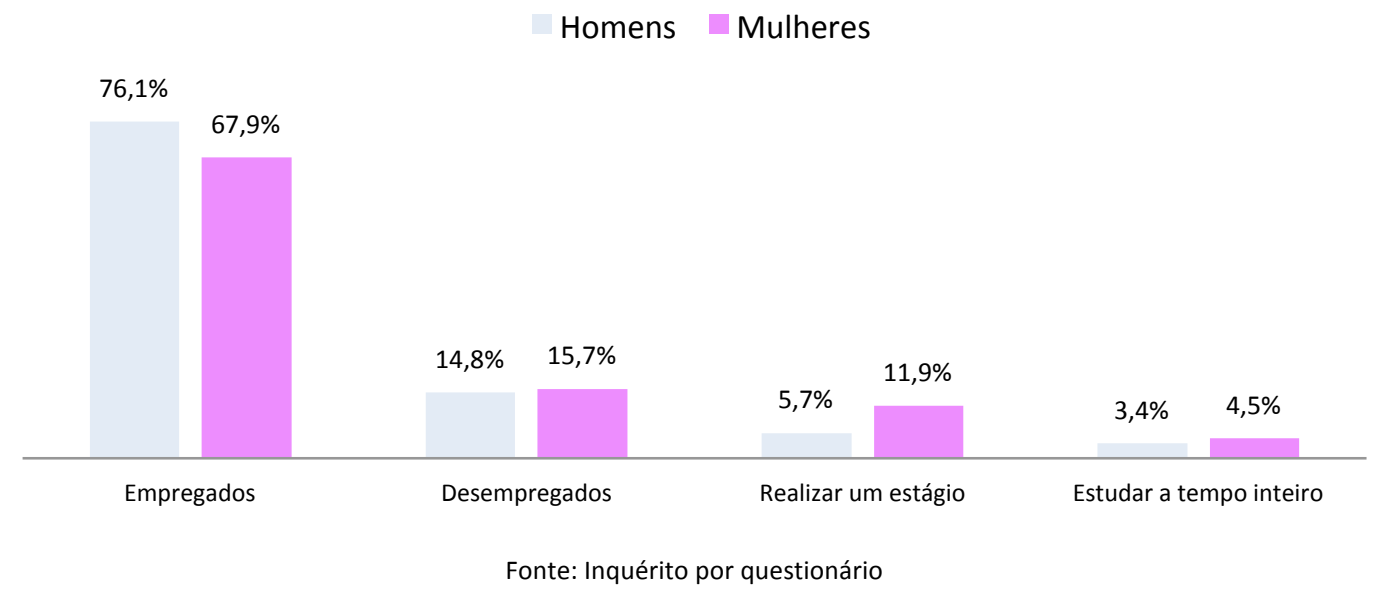

No que diz respeito à situação profissional dos inquiridos constata-se que, os licenciados nos cursos em regime pós laboral e noturno apresentam taxas de inserção profissional muito elevadas. Com efeito, em Gestão da Distribuição e da Logística (regime pós laboral) todos os inquiridos se encontram empregados sendo que, em Gestão de Recursos Humanos (regime pós laboral) 91,7\% também já se encontram, atualmente, inseridos no mercado de trabalho. Em Contabilidade e Finanças (regime noturno) mais de $75 \%$ dos licenciados estão empregados.

Em regime diurno, destacam-se os licenciados em Gestão de Sistemas de Informação uma vez que 81,9\% também se encontram empregados. Os licenciados em Gestão de Recursos Humanos e em Contabilidade e Finanças são os que apresentam as taxas de emprego mais baixas sendo, no entanto, os cursos onde existem mais licenciados a estudar a tempo inteiro $(10,5 \%$ e $7 \%$, respetivamente).

As taxas de desemprego mais altas encontram-se também entre os licenciados em Contabilidade e Finanças $(20,9 \%)$ e Gestão de Recursos Humanos $(21,1 \%)$. O estágio profissional é, ainda, a realidade profissional de $8,8 \%$ dos licenciados não existindo, no entanto, diplomados do curso de Gestão da Distribuição e da Logística (regime pós laboral) e Gestão de Recursos Humanos (regime pós laboral) neste universo de inquiridos. 
Quadro 18 - Situação profissional dos inquiridos licenciados da ESCE/IPS por curso

\begin{tabular}{|c|c|c|c|c|}
\hline & Empregado & Realizar estágio & Desempregado & $\begin{array}{l}\text { Estudar a tempo } \\
\text { inteiro }\end{array}$ \\
\hline $\begin{array}{l}\text { Contabilidade e Finanças (regime } \\
\text { noturno) }\end{array}$ & $76,7 \%$ & $6,7 \%$ & $16,6 \%$ & $0,0 \%$ \\
\hline Contabilidade e Finanças & $60,5 \%$ & $11,6 \%$ & $20,9 \%$ & $7,0 \%$ \\
\hline $\begin{array}{l}\text { Gestão da Distribuição e da } \\
\text { Logística (pós laboral) }\end{array}$ & $100,0 \%$ & $0,0 \%$ & $0,0 \%$ & $0,0 \%$ \\
\hline $\begin{array}{l}\text { Gestão da Distribuição e da } \\
\text { Logística }\end{array}$ & $80,0 \%$ & $6,7 \%$ & $13,3 \%$ & $0,0 \%$ \\
\hline $\begin{array}{l}\text { Gestão de Recursos Humanos (pós } \\
\text { laboral) }\end{array}$ & $91,7 \%$ & $0,0 \%$ & $8,3 \%$ & $0,0 \%$ \\
\hline Gestão de Recursos Humanos & $57,9 \%$ & $10,5 \%$ & $21,1 \%$ & $10,5 \%$ \\
\hline Gestão de Sistemas de Informação & $81,9 \%$ & $9,1 \%$ & $4,5 \%$ & $4,5 \%$ \\
\hline Marketing & $64,9 \%$ & $16,2 \%$ & $16,2 \%$ & $2,7 \%$ \\
\hline TOTAL ESCE/IPS & $72 \%$ & $8,8 \%$ & $15,2 \%$ & $4,0 \%$ \\
\hline
\end{tabular}

Fonte: Inquérito por questionário

Relativamente à situação na profissão, os licenciados empregados trabalham, na sua maioria, por conta de outrem $(92,4 \%)$, sendo apenas $7 \%$ os que trabalham por conta própria e $0,6 \%$ os que se encontram noutra situação. $O$ trabalho por conta própria apresenta maior expressão entre os licenciados nos cursos de Contabilidade e Finanças $(11,5 \%)$ e Gestão de Recursos Humanos regime pós laboral $(18,2 \%)$. Os inquiridos do curso de Gestão da Distribuição e da Logística em regime pós laboral trabalham, na sua totalidade, por conta de outrem.

Quadro 19 - Situação na profissão dos inquiridos licenciados da ESCE/IPS por curso

\begin{tabular}{|c|c|c|c|}
\hline & $\begin{array}{l}\text { Trabalhador por } \\
\text { conta de outrem }\end{array}$ & $\begin{array}{l}\text { Trabalhador por } \\
\text { conta própria }\end{array}$ & Outra Situação \\
\hline $\begin{array}{l}\text { Contabilidade e Finanças (regime } \\
\text { noturno) }\end{array}$ & $91,3 \%$ & $4,3 \%$ & $4,3 \%$ \\
\hline Contabilidade e Finanças & $88,5 \%$ & $11,5 \%$ & $0,0 \%$ \\
\hline $\begin{array}{l}\text { Gestão da Distribuição e da Logística } \\
\text { (pós laboral) }\end{array}$ & $100,0 \%$ & $0,0 \%$ & $0,0 \%$ \\
\hline Gestão da Distribuição e da Logística & $95,8 \%$ & $4,2 \%$ & $0,0 \%$ \\
\hline $\begin{array}{l}\text { Gestão de Recursos Humanos (pós } \\
\text { laboral) }\end{array}$ & $81,8 \%$ & $18,2 \%$ & $0,0 \%$ \\
\hline Gestão de Recursos Humanos & $95,8 \%$ & $4,2 \%$ & $0,0 \%$ \\
\hline Gestão de Sistemas de Informação & $94,4 \%$ & $5,6 \%$ & $0,0 \%$ \\
\hline Marketing & $91,7 \%$ & $8,3 \%$ & $0,0 \%$ \\
\hline TOTAL ESCE/IPS & $92,4 \%$ & $7,0 \%$ & $0,6 \%$ \\
\hline \multicolumn{4}{|c|}{ Fonte: Inquérito por questionário } \\
\hline
\end{tabular}


O contrato de trabalho por tempo indeterminado é o vínculo contratual com maior expressão entre os inquiridos empregados $(53,2 \%)$ apesar de $38,6 \%$ afirmarem deter um contrato de trabalho a prazo. Cerca de 6,3\% indicam ainda possuir um contrato de prestação de serviços e 1,9\% encontram-se noutra situação não especificada.

Da análise por curso conclui-se, ainda, que são sobretudo os licenciados nos cursos lecionados em regime noturno e pós laboral que apresentam uma relação de trabalho com maior estabilidade detendo um contrato de trabalho sem termo. Por outro lado, são os empregados licenciados nos cursos de Gestão da Distribuição e da Logística, Gestão de Sistemas de Informação e Marketing que possuem, em maior número, um contrato de trabalho a prazo $(54,2 \%, 61,1 \%$ e $54,2 \%$, respetivamente).

De referir, ainda, que é entre os licenciados nos cursos de Contabilidade e Finanças (regime noturno) e Gestão de Recursos Humanos que se verifica uma maior diversificação nas relações de trabalho existentes.

Pode aferir-se, no gráfico infra, que são nos cursos de Contabilidade e Finanças, Gestão de Recursos Humanos (regime pós laboral) e Marketing que se encontra uma maior precariedade em termos de vínculo laboral ( $11,5 \%, 9,1 \%$ e $8,3 \%$ possuem um contrato de prestação de serviços), apesar de pouco expressiva.

Gráfico 24 - Vínculo laboral, por curso, dos inquiridos licenciados da ESCE/IPS

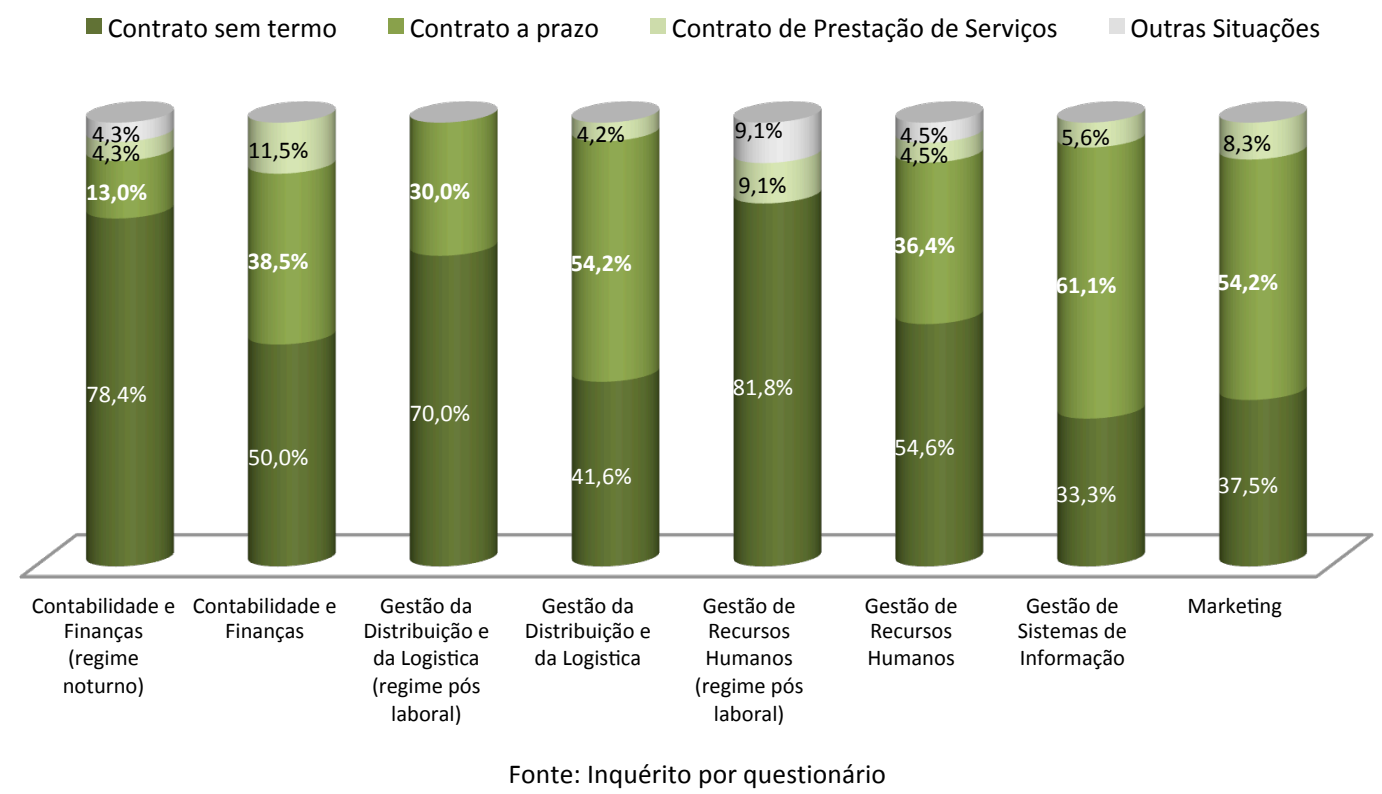


O tempo de trabalho predominante entre os licenciados empregados é o regime de tempo inteiro (93\%), surgindo o regime de tempo parcial para apenas $7 \%$ dos inquiridos.

Os licenciados nos cursos de Gestão da Distribuição e Logística (regime pós laboral), Gestão de Recursos Humanos (regime pós laboral) e Gestão de Sistemas de Informação praticam, unicamente, o regime de trabalho a tempo integral, sendo o curso de Gestão de Recursos Humanos o detentor da taxa mais alta de trabalhadores a tempo parcial $(18,2 \%)$.

Gráfico 25 - Duração do tempo de trabalho, por curso, dos inquiridos licenciados da ESCE/IPS

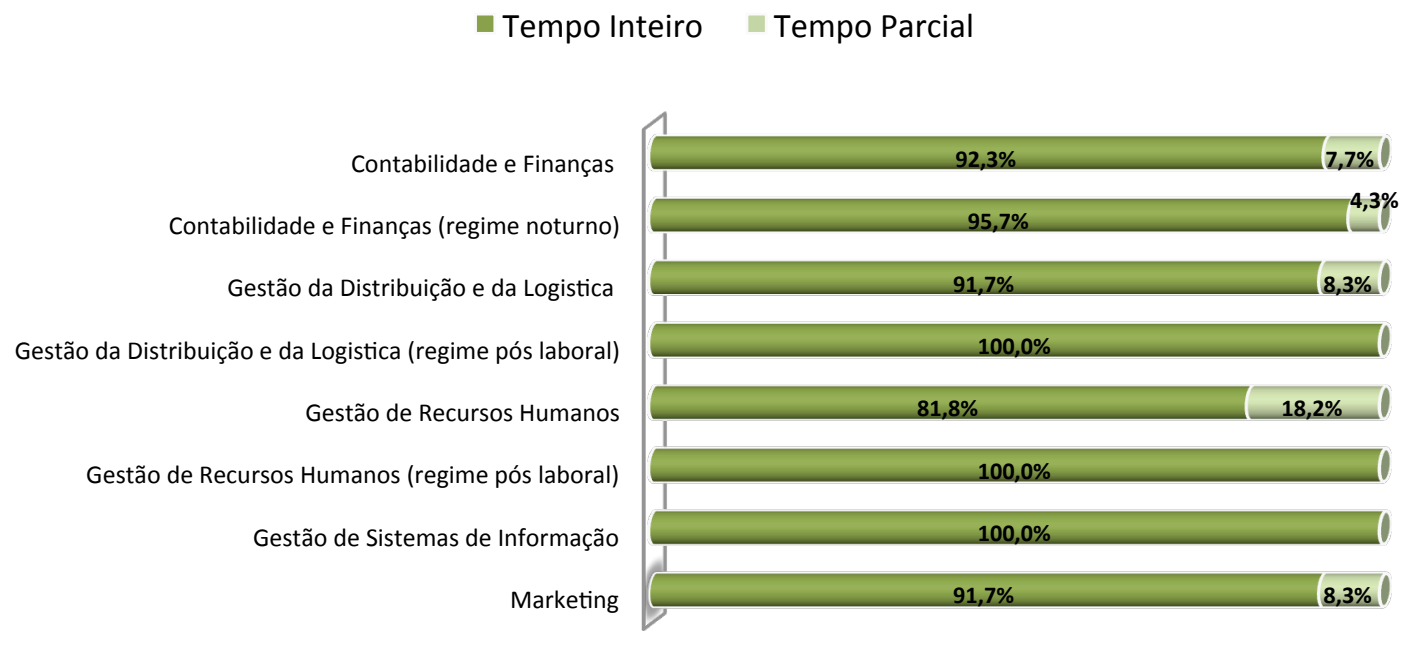

Fonte: Inquérito por questionário

\subsection{2 - Tipo de empresa/organização, localização geográfica e nível de remuneração}

Também os licenciados nos cursos da ESCE/IPS se encontram empregados essencialmente em empresas do setor privado $(80,4 \%)$, sendo as empresas entre 9 e 99 trabalhadores que mais recrutam estes diplomados (36,7\%). A Administração Pública é responsável pela inserção profissional de $16,4 \%$ licenciados e as ONG/IPSS apresentam-se, neste universo, com valores pouco expressivos $(0,6 \%)$. 
Gráfico 26 - Tipo de empresa/organização onde trabalham os inquiridos licenciados da ESCE/IPS

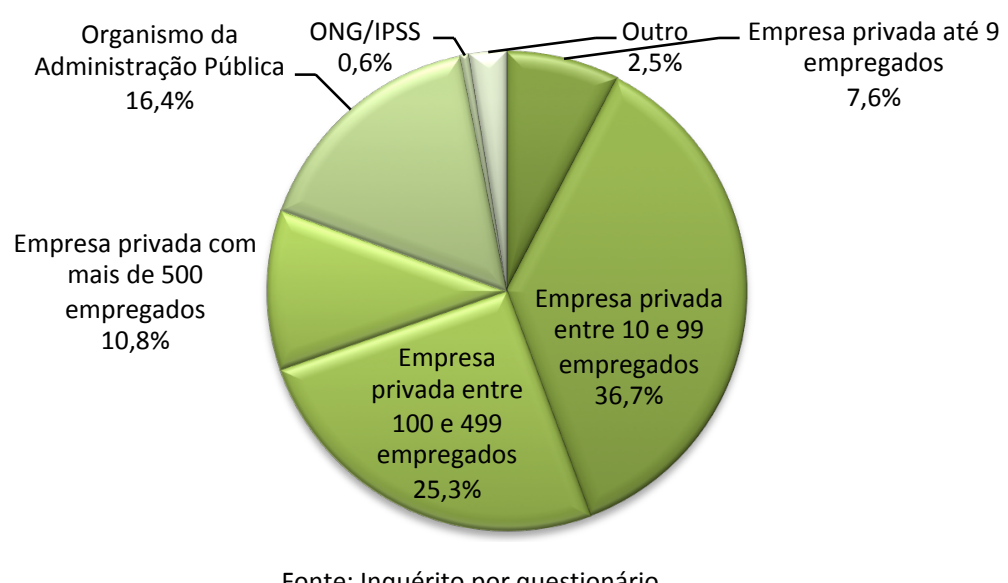

Fonte: Inquérito por questionário

Conforme se pode aferir no quadro infra, são essencialmente os licenciados em Gestão de Recursos Humanos (regime diurno e regime pós laboral), Gestão de Sistemas de Informação e Gestão da Distribuição e da Logística (regime pós laboral) que estão empregados no setor público (36,4\%, 27,3\%, $22,2 \%$ e $20 \%$ respetivamente). No entanto, o sector privado tende a ser o principal empregador dos licenciados da ESCE/IPS com forte expressão nos cursos de Contabilidade e Finanças (78,1\% no regime noturno e $80,7 \%$ no regime diurno), Gestão da Distribuição e da Logística (91,7\%) e Marketing (91,6\%). A inserção dos licenciados em ONG/IPSS apenas se verifica no curso de Marketing $(4,2 \%)$.

Quadro 20 - Dimensão da empresa/organização, por curso, onde trabalham os inquiridos licenciados da ESCE/IPS

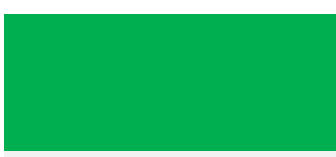

Contabilidade e Finanças (regime noturno)

Contabilidade e Finanças

Gestão da Distribuição e da Logística (pós laboral) Gestão da Distribuição e da Logística

Gestão de Recursos Humanos (pós laboral) Gestão de Recursos Humanos Gestão de Sistemas de Informação

Marketing

TOTAL ESCE/IPS

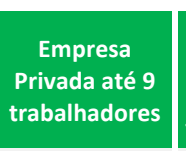

Empresa
Privada entre
10 a 99
trabalhadores

$21,7 \%$

$11,5 \%$

$21,7 \%$

$34,6 \%$

$0,0 \%$

$0,0 \%$

$9,1 \%$

$0,0 \%$

$5,6 \%$

$8,3 \%$

$7,6 \%$

$40,0 \%$

$29,2 \%$

$27,3 \%$

$31,8 \%$

$61,1 \%$

$50,0 \%$

$36,7 \%$

\begin{tabular}{c|c}
\hline Empresa \\
Privada entre \\
100 a 499 \\
trabalhadores
\end{tabular}

Empresa

Privada com mais de $\mathbf{5 0 0}$ trabalhadores trabalhadores

\begin{tabular}{|l|l}
\hline $21,7 \%$ & $13,0 \%$
\end{tabular}

$23,1 \%$

$11,5 \%$

$10,0 \%$

$30,0 \%$

$45,8 \%$

$16,7 \%$

$27,3 \%$

$18,2 \%$

$0,0 \%$

$18,2 \%$

Fonte: Inquérito por questionário

$11,1 \%$

$0,0 \%$

$33,3 \%$

$0,0 \%$

$10,8 \%$
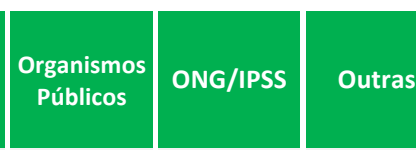

$13,0 \%$

$0,0 \%$

$8,7 \%$

$14,4 \% \quad 0,0 \%$

$3,8 \%$

\begin{tabular}{|l|l}
$20,0 \%$ & $0,0 \%$
\end{tabular}

$0,0 \%$

$8,3 \% \quad 0,0 \%$

$0,0 \%$

\begin{tabular}{|l|l|l|}
\hline $36,4 \%$ & $0,0 \%$ & $0,0 \%$ \\
\hline
\end{tabular}

$27,3 \% \quad 0,0 \%$

$4,5 \%$

\begin{tabular}{|l|l|l}
\hline $22,2 \%$ & $0,0 \%$ & $0,0 \%$ \\
\hline
\end{tabular}

$4,2 \%$

$4,2 \%$

$0,0 \%$

$16,4 \%$

$0,6 \%$

$2,5 \%$ 
Relativamente ao setor de atividade das entidades empregadoras verifica-se que os licenciados empregados se encontram distribuídos essencialmente pelos setores dos serviços prestados às empresas $(25,3 \%)$, comércio $(17,7 \%)$, indústria transformadora, eletricidade, água e gás e construção de obras públicas $(10,8 \%)$ e transportes e comunicações $(10,1 \%)$.

Os concelhos mais apontados pelos inquiridos como sendo a localização onde trabalham são Lisboa $(33,8 \%)$ e Setúbal $(26,8 \%)$ verificando-se, no entanto, que a maioria dos inquiridos trabalha na margem sul do Tejo. De referir ainda a existência de $0,6 \%$ de diplomados que trabalha no Reino Unido (1 licenciado em Gestão de Recursos Humanos).

Gráfico 27 - Localização geográfica da empresa/organização onde trabalham os inquiridos licenciados da ESCE/IPS

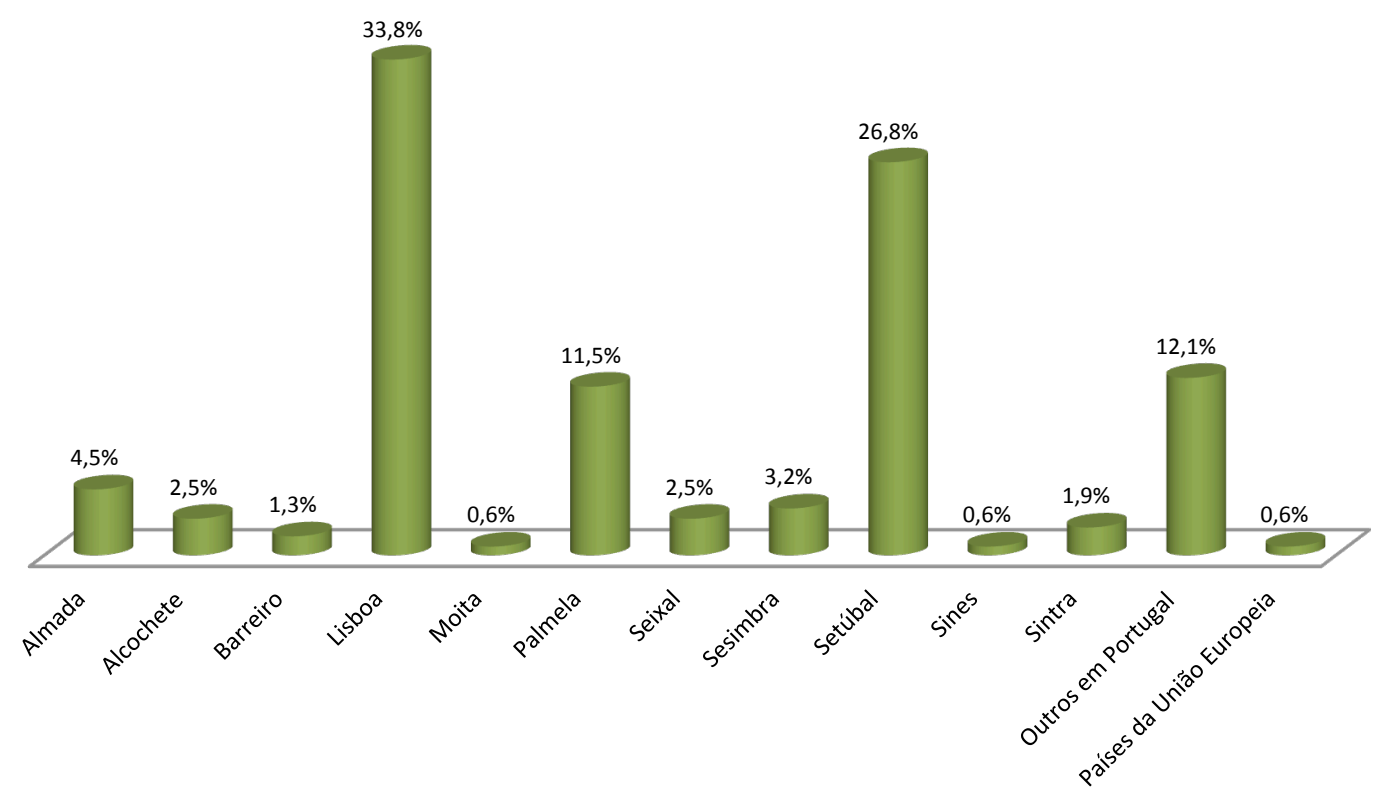

Fonte: Inquérito por questionário

No que diz respeito ao salário líquido mensal auferido pelos licenciados empregados, verifica-se que o escalão 751-1.000€ representa a realidade de 37,6\% dos respondentes. A auferir menos de $501 €$ líquidos mensais encontram-se cerca de $11,4 \%$ dos inquiridos.

Importa referir, que no escalão de rendimentos mais alto (mais de 1.250€) inserem-se cerca de $11,4 \%$ do universo de inquiridos empregados, destacando-se os licenciados em Contabilidade e Finanças em regime noturno (22,7\%) e Gestão de Recursos Humanos (18,2\%) e os licenciados em Contabilidade e Finanças (diurno), Gestão da Distribuição e da Logística (pós laboral) e Gestão de Sistemas de Informação, com valores acima dos $10 \%$. 
Apesar de se verificar uma distribuição dos inquiridos por todos os escalões remuneratórios constata-se que os licenciados em Gestão da Distribuição e da Logística pós laboral, Gestão de Recursos Humanos pós laboral e Gestão de Sistemas de Informação tendem a situar-se, com maior expressão, no escalão correspondente a 751 - $1.000 €(62,5 \%, 66,7 \%$ e $77,8 \%$, respetivamente).

No escalão remuneratório entre os 501 - $750 €$ inserem-se, essencialmente, os diplomados dos cursos de Contabilidade e Finanças (62,5\%).

Quadro 21 - Remuneração mensal líquida, por curso, dos inquiridos licenciados da ESCE/IPS

\begin{tabular}{|c|c|c|c|c|c|c|}
\hline & Até $250 €$ & $251-500 €$ & $501-750 €$ & $\begin{array}{c}751- \\
1.000 €\end{array}$ & $\begin{array}{l}1.001- \\
1.250 €\end{array}$ & $\begin{array}{l}\text { Mais de } \\
1.250 €\end{array}$ \\
\hline $\begin{array}{l}\text { Contabilidade e Finanças } \\
\text { (regime noturno) }\end{array}$ & $4,5 \%$ & $9,1 \%$ & $27,3 \%$ & $18,2 \%$ & $18,2 \%$ & $22,7 \%$ \\
\hline Contabilidade e Finanças & $0,0 \%$ & $8,3 \%$ & $62,5 \%$ & $12,5 \%$ & $4,2 \%$ & $12,5 \%$ \\
\hline $\begin{array}{l}\text { Gestão da Distribuição e da } \\
\text { Logística (pós laboral) }\end{array}$ & $0,0 \%$ & $12,5 \%$ & $0,0 \%$ & $62,5 \%$ & $12,5 \%$ & $12,5 \%$ \\
\hline $\begin{array}{l}\text { Gestão da Distribuição e da } \\
\text { Logística }\end{array}$ & $0,0 \%$ & $8,7 \%$ & $43,5 \%$ & $34,8 \%$ & $8,7 \%$ & $4,3 \%$ \\
\hline $\begin{array}{l}\text { Gestão de Recursos } \\
\text { Humanos (pós laboral) }\end{array}$ & $0,0 \%$ & $10,0 \%$ & $22,2 \%$ & $66,7 \%$ & $11,1 \%$ & $0,0 \%$ \\
\hline $\begin{array}{l}\text { Gestão de Recursos } \\
\text { Humanos }\end{array}$ & $4,5 \%$ & $13,6 \%$ & $22,7 \%$ & $31,8 \%$ & $9,1 \%$ & $18,2 \%$ \\
\hline $\begin{array}{l}\text { Gestão de Sistemas de } \\
\text { Informação }\end{array}$ & $0,0 \%$ & $0,0 \%$ & $5,6 \%$ & $77,8 \%$ & $5,6 \%$ & $11,1 \%$ \\
\hline Marketing & $0,0 \%$ & $21,7 \%$ & $30,4 \%$ & $39,1 \%$ & $4,3 \%$ & $4,3 \%$ \\
\hline TOTAL ESCE/IPS & $1,3 \%$ & $10,1 \%$ & $30,9 \%$ & $37,6 \%$ & $8,7 \%$ & $11,4 \%$ \\
\hline
\end{tabular}

Fonte: Inquérito por questionário

\subsection{3 - Meios de acesso ao emprego}

No que concerne aos meios facilitadores da entrada no mercado de trabalho destaca-se a importância do estágio curricular como o principal meio de inserção profissional $(21,2 \%)$ para alguns destes diplomados, a resposta a anúncios $(17,7 \%)$, amigos e colegas $(14,2 \%)$, candidatura espontânea $(13,3 \%)$ e portal emprego $(9,7 \%)$ como porta de entrada na vida ativa, denotando-se alguma proatividade por parte destes licenciados. 
Gráfico 28 - Meios de acesso ao emprego, dos inquiridos licenciados da ESCE/IPS

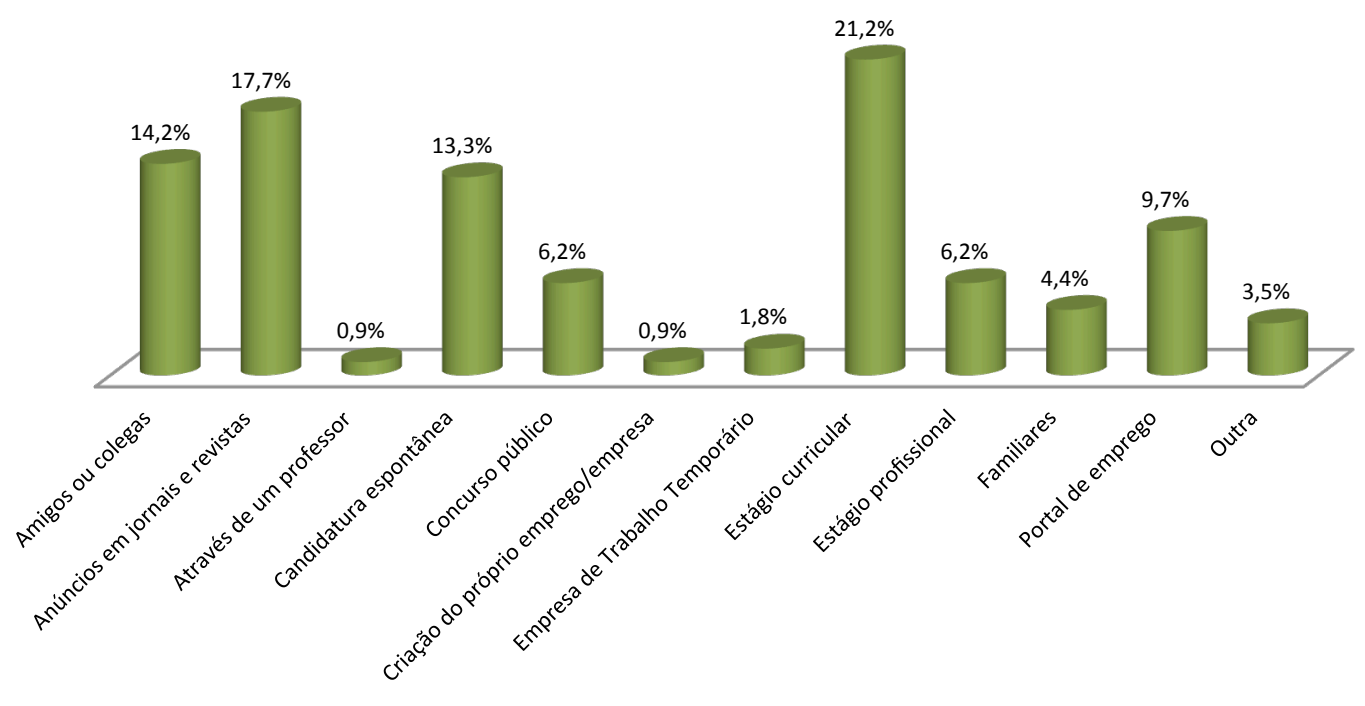

Fonte: Inquérito por questionário

\subsection{4 - Relação entre o emprego e a área de formação académica}

Relativamente a esta dimensão da integração profissional dos diplomados conclui-se que, $58,5 \%$ se encontra a desempenhar funções diretamente relacionadas com a sua área de estudo, encontrando-se $23,3 \%$ a trabalhar em áreas completamente distintas.

Os licenciados em Gestão de Sistema de Informação são os que maior correspondência encontram entre a atividade profissional que desenvolvem e a área de formação em que se diplomaram (100\%). Também os diplomados em Contabilidade e Finanças (65,4\% regime diurno e $75 \%$ regime noturno), Gestão da Distribuição e da Logística (70,8\% regime diurno e $60 \%$ regime pós laboral) trabalham numa atividade diretamente ligada à formação académica obtida.

São, no entanto, os licenciados em Gestão de Recursos Humanos (45,5\% regime diurno e 54,5\% regime pós laboral), que menor correspondência encontram entre o emprego que detêm e a licenciatura em que se diplomaram. 
Quadro 22 - Relação entre a atividade profissional remunerada dos inquiridos licenciados da ESCE/IPS e a área do curso

\begin{tabular}{|c|c|c|c|}
\hline & $\begin{array}{c}\text { Atividade } \\
\text { diretamente } \\
\text { relacionada com a } \\
\text { área da licenciatura }\end{array}$ & $\begin{array}{l}\text { Atividade numa área } \\
\text { próxima da } \\
\text { licenciatura }\end{array}$ & $\begin{array}{c}\text { Atividade numa área } \\
\text { totalmente diferente } \\
\text { da área da } \\
\text { licenciatura }\end{array}$ \\
\hline $\begin{array}{l}\text { Contabilidade e Finanças (regime } \\
\text { noturno) }\end{array}$ & $75,0 \%$ & $16,7 \%$ & $8,3 \%$ \\
\hline Contabilidade e Finanças & $65,4 \%$ & $11,5 \%$ & $23,1 \%$ \\
\hline $\begin{array}{l}\text { Gestão da Distribuição e da Logística } \\
\text { (pós laboral) }\end{array}$ & $60,0 \%$ & $20,0 \%$ & $20,0 \%$ \\
\hline Gestão da Distribuição e da Logística & $70,8 \%$ & $12,5 \%$ & $16,7 \%$ \\
\hline $\begin{array}{l}\text { Gestão de Recursos Humanos (pós } \\
\text { laboral) }\end{array}$ & $27,3 \%$ & $18,2 \%$ & $54,5 \%$ \\
\hline Gestão de Recursos Humanos & $18,2 \%$ & $36,4 \%$ & $45,5 \%$ \\
\hline Gestão de Sistemas de Informação & $100,0 \%$ & $0,0 \%$ & $0,0 \%$ \\
\hline Marketing & $41,6 \%$ & $29,2 \%$ & $29,2 \%$ \\
\hline TOTAL ESCE/IPS & $58,5 \%$ & $18,2 \%$ & $23,3 \%$ \\
\hline
\end{tabular}

No que concerne à profissão desenvolvida pelos inquiridos verifica-se que os licenciados em Contabilidade e Finanças trabalham como Técnicos Oficiais de Contas, Técnicos Tributários, Auditores, Consultores Financeiros existindo, também, alguns inquiridos que indicam encontrar-se inseridos na área comercial como técnico de vendas.

Os licenciados em Gestão da Distribuição e da Logística apontam, como principais atividades profissionais desenvolvidas, a Gestão de Frotas, Gestão de Stocks, Gestão de Clientes, Operador Transitário, Técnico de Logística, Formador e Operador de Supermercado.

Por outro lado, encontramos entre os inquiridos de Gestão de Recursos Humanos uma maior dispersão relativamente às atividades profissionais desenvolvidas. Pese embora, a profissão de Técnico de Recursos Humanos e Técnico de Segurança e Higiene no Trabalho sejam as que assumem maior representação, existem ainda licenciados a exercer funções administrativas, comerciais, técnico de call center, operador de supermercado, consultor imobiliário e formador.

Os licenciados em Gestão de Sistemas de Informação estão, atualmente, a desempenhar funções diretamente ligadas à área de formação académica sendo, as profissões de Consultor Informático, Programador e Analista Funcional, as mais referenciadas. 
Relativamente ao curso de Marketing verifica-se que os licenciados inserem-se, sobretudo, na área comercial desempenhando funções de Técnico Comercial, Assistente de Marketing, Avaliador de Estudos de Mercado, Designer Gráfico existindo, no entanto, um grupo significativo de inquiridos que trabalham como operador de call center e administrativo.

\section{5 - Escola Superior de Tecnologia do Barreiro}

Na ESTB/IPS estamos perante uma amostra essencialmente masculina, que representa $83,3 \%$ do universo de inquiridos. Apenas o curso de Engenharia Química apresenta uma amostra de $100 \%$ de inquiridos do género feminino, pelo facto de existir apenas uma diplomada no ano letivo 2010/2011, neste curso.

Nas licenciaturas em Gestão da Construção, quer no regime diurno ou noturno, a amostra é constituída apenas por inquiridos do género masculino.

Gráfico 29 - Distribuição dos inquiridos licenciados da ESTB/IPS por curso e género

Masculino Feminino

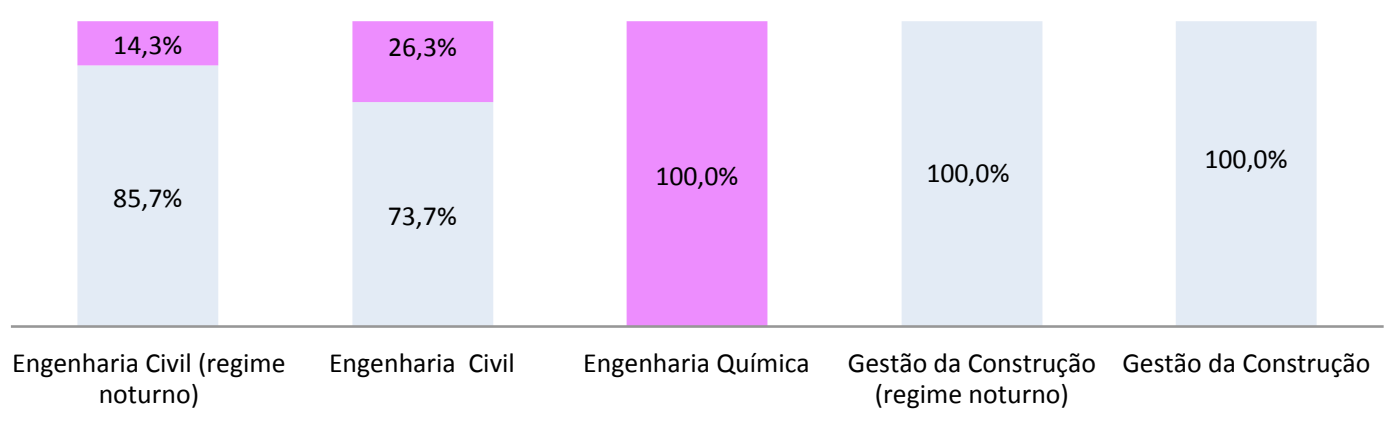

Fonte: Inquérito por questionário

\subsection{1 - Situação Profissional}

De acordo com a análise dos resultados conclui-se que cerca de $66,7 \%$ dos inquiridos se encontram atualmente empregados existindo, no entanto, uma taxa de $25,9 \%$ de desemprego entre estes licenciados. Neste universo de inquiridos verifica-se, ainda, que $5,6 \%$ se encontram a estudar a tempo inteiro e $1,9 \%$ realizam um estágio profissional.

Como se pode constatar no gráfico infra, são essencialmente as mulheres que se encontram em situação de desemprego (66,7\% mulheres desempregadas, $17,8 \%$ homens desempregados). Por outro lado, também são as mulheres que apostam na prossecução dos estudos a tempo inteiro 
$(11,1 \%)$ talvez pela dificuldade que enfrentam aquando da sua inserção na vida ativa, tendo em conta as taxas de desemprego apresentadas.

Gráfico 30 - Situação profissional dos inquiridos licenciados da ESTB/IPS por género

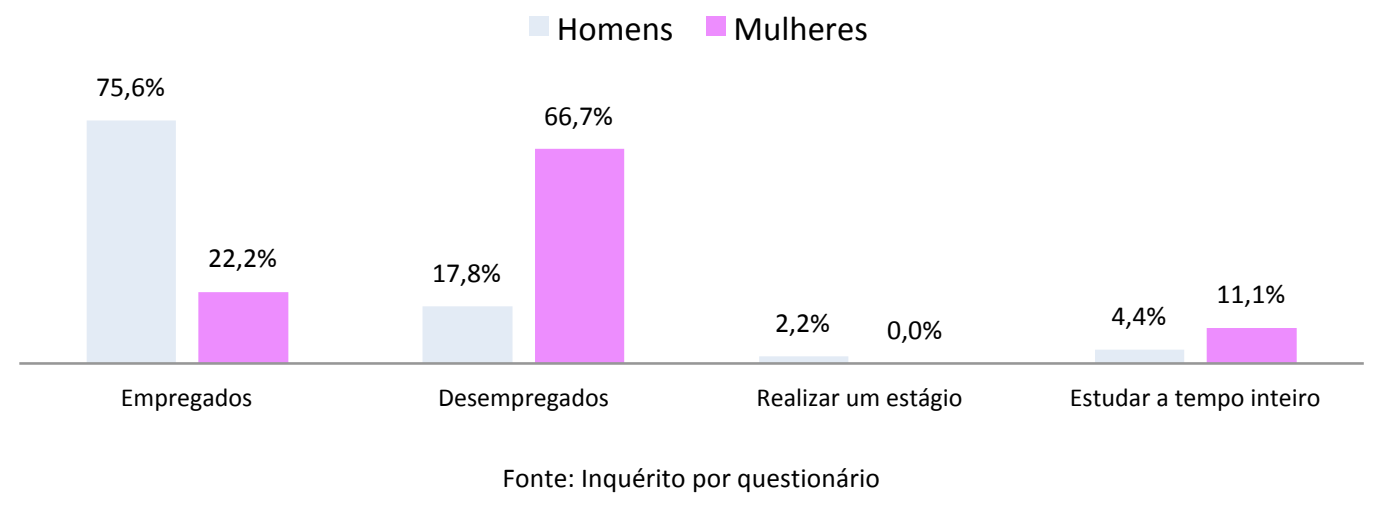

Como se podem observar, são os licenciados nos cursos de Gestão da Construção, em regime diurno e noturno, que registam as taxas de inserção profissional mais altas (100\% e $87,5 \%$ respetivamente). O desemprego total encontra-se no curso de Engenharia Química, no entanto, o facto de existir apenas 1 diplomado condiciona, de certa forma, a leitura destes resultados. A prossecução dos estudos a tempo inteiro é apenas uma aposta dos licenciados em Engenharia Civil $(15,8 \%)$.

Quadro 23 - Situação profissional dos inquiridos licenciados da ESTB/IPS por curso

\begin{tabular}{|l|c|c|c|c|}
\hline & Empregado & Realizar estágio & Desempregado & $\begin{array}{c}\text { Estudar a } \\
\text { tempo inteiro }\end{array}$ \\
\hline Engenharia Civil (regime noturno) & $76,2 \%$ & $0,0 \%$ & $23,8 \%$ & $0,0 \%$ \\
\hline Engenharia Civil & $42,1 \%$ & $5,3 \%$ & $36,8 \%$ & $15,8 \%$ \\
\hline Engenharia Química & $0,0 \%$ & $0,0 \%$ & $100,0 \%$ & $0,0 \%$ \\
\hline Gestão da Construção (regime noturno) & $87,5 \%$ & $0,0 \%$ & $12,5 \%$ & $0,0 \%$ \\
\hline Gestão da Construção & $100,0 \%$ & $0,0 \%$ & $0,0 \%$ & $0,0 \%$ \\
\hline T O T A L ESTB/IPS & $\mathbf{6 6 , 7 \%}$ & $\mathbf{1 , 9}$ & $\mathbf{2 5 , 9 \%}$ & $\mathbf{5 , 6 \%}$ \\
\hline
\end{tabular}

Fonte: Inquérito por questionário 
O quadro infra pretende apresentar a situação na profissão dos inquiridos empregados, pelo que nos próximos indicadores não estará sujeito a análise o curso de Engenharia Química pelas razões já invocadas (apenas 1 diplomado que se encontra em situação de desemprego).

No que concerne à situação na profissão, conclui-se que $77,8 \%$ dos inquiridos empregados trabalham por conta de outrem e os restantes por conta própria $(22,2 \%)$.

Quadro 24 - Situação na Profissão dos inquiridos licenciados da ESTB/IPS por curso

\begin{tabular}{|c|c|c|c|}
\hline & $\begin{array}{l}\text { Trabalhador por } \\
\text { conta de outrem }\end{array}$ & $\begin{array}{c}\text { Trabalhador por } \\
\text { conta própria }\end{array}$ & Outra Situação \\
\hline Engenharia Civil (regime noturno) & $75,0 \%$ & $25,0 \%$ & $0,0 \%$ \\
\hline Engenharia Civil & $75,0 \%$ & $25,0 \%$ & $0,0 \%$ \\
\hline $\begin{array}{l}\text { Gestão da Construção (regime } \\
\text { noturno) }\end{array}$ & $85,7 \%$ & $14,3 \%$ & $0,0 \%$ \\
\hline Gestão da Construção & $80,0 \%$ & $20,0 \%$ & $0,0 \%$ \\
\hline TOT A L ESTB/IPS & $77,8 \%$ & $22,2 \%$ & $0,0 \%$ \\
\hline
\end{tabular}

Fonte: Inquérito por questionário

No que diz respeito ao vínculo laboral conclui-se que o contrato de trabalho sem termo é o mais apontado pelos inquiridos $(69,5 \%)$ especialmente entre os licenciados em Engenharia Civil regime noturno e Gestão da Construção regime noturno ( $75 \%$ e $85,7 \%$, respetivamente). O contrato de trabalho a prazo e o contrato de prestação de serviços são o vínculo contratual estabelecido com $22,2 \%$ dos inquiridos.

Gráfico 31 - Vínculo laboral dos inquiridos licenciados da ESTB/IPS por curso घ Contrato sem termo $\quad$ Contrato a prazo $\quad$ Contrato de Prestação de Serviços $\square$ Outra Situação

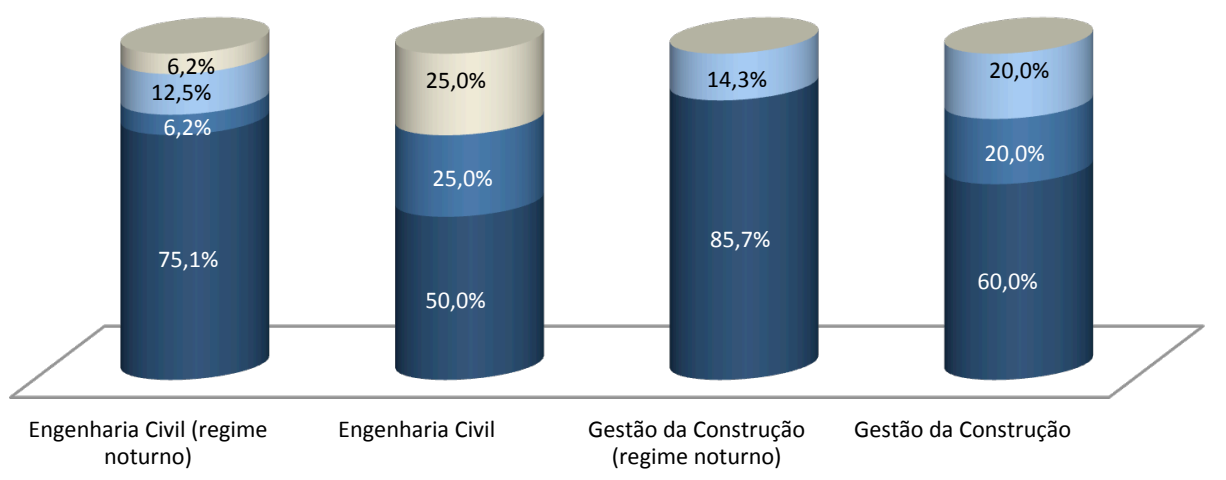

Fonte: Inquérito por questionário 
O emprego a tempo inteiro é praticado por cerca de $91,7 \%$ dos inquiridos verificando-se que todos os licenciados nos cursos em regime noturno se encontram a trabalham num horário completo. São, sobretudo, os licenciados no curso de Engenharia Civil e Gestão da Construção, ambos em regime diurno, que praticam o horário a tempo parcial ( $25 \%$ e $20 \%$, respetivamente).

Gráfico 32 - Duração do tempo de trabalho dos inquiridos licenciados da ESTB/IPS por curso

$$
\text { - Tempo Inteiro Tempo Parcial }
$$

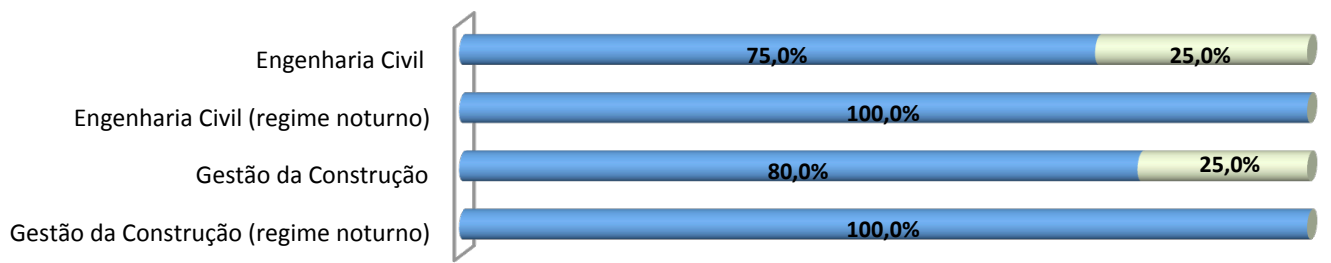

Fonte: Inquérito por questionário

\subsection{2 - Tipo de empresa/organização, localização geográfica e nível de remuneração}

A maioria dos diplomados da ESTB/IPS encontram-se inseridos profissionalmente no setor privado $(71,7 \%)$, pese embora o setor público representar $28,3 \%$ do universo de empregadores. No que diz respeito à dimensão das empresas privadas são, maioritariamente, as pequenas e médias empresas com menos de 100 trabalhadores que empregam os licenciados inquiridos $(47,5 \%)$. No entanto, as empresas do setor privado com 100 ou mais trabalhadores surgem também como as entidades patronais de $24,2 \%$ dos diplomados empregados.

Gráfico 33 - Tipo de empresa/organização onde trabalham os inquiridos licenciados da ESTB/IPS

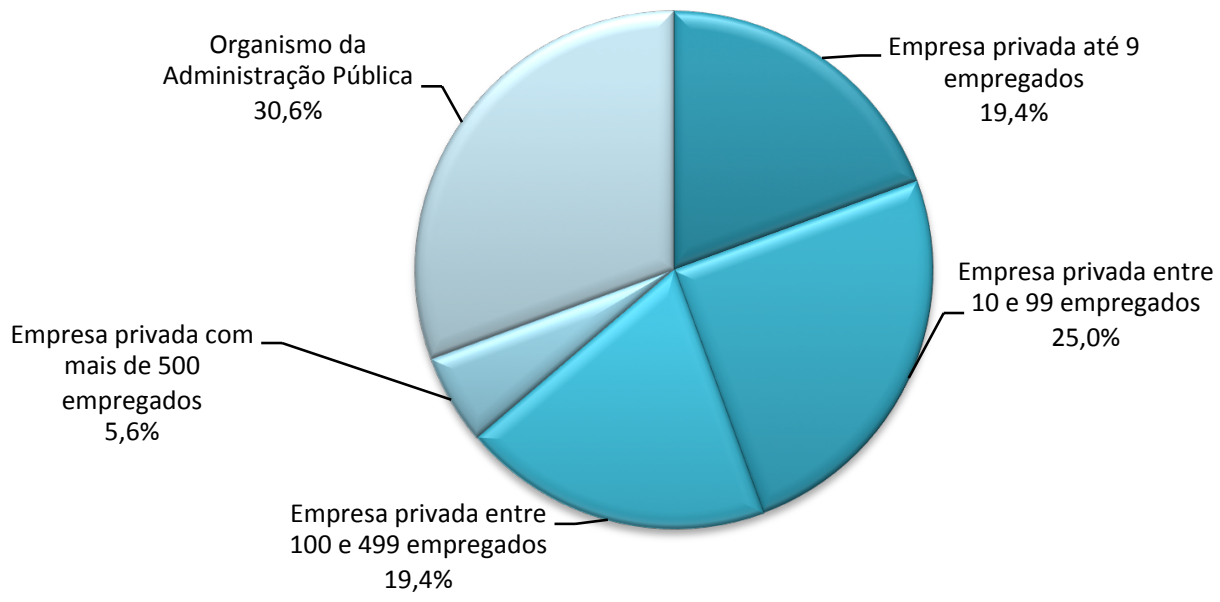

Fonte: Inquérito por questionário 
Conforme se pode verificar no quadro infra, a administração pública emprega, cerca de $57,1 \%$ dos licenciados em Gestão da Construção (regime noturno). Também 31,2\% dos diplomados em Engenharia Civil (regime noturno) se encontram inseridos neste setor. Por outro lado, os inquiridos do curso de Gestão da Construção tendem a ser absorvidos pelas empresas do setor privado com menos de 100 trabalhadores (80\%) não se registando diplomados, deste curso, a trabalhar na Administração Pública.

Nas empresas privadas de grande dimensão (mais de 500 trabalhadores) encontram-se apenas inseridos os licenciados em Engenharia Civil regime noturno (12,5\%).

Quadro 25 - Dimensão da empresa/organização, por curso, onde trabalham os inquiridos licenciados da ESTB/IPS

\begin{tabular}{|c|c|c|c|c|c|}
\hline & $\begin{array}{c}\text { Empresa } \\
\text { Privada até } 9 \\
\text { trabalhadores }\end{array}$ & $\begin{array}{c}\text { Empresa } \\
\text { Privada entre } \\
10 \text { a } 99 \\
\text { trabalhadores }\end{array}$ & $\begin{array}{c}\text { Empresa } \\
\text { Privada entre } \\
100 \text { a } 499 \\
\text { trabalhadores }\end{array}$ & $\begin{array}{l}\text { Empresa } \\
\text { Privada com } \\
\text { mais de } 500 \\
\text { trabalhadores }\end{array}$ & $\begin{array}{l}\text { Organismos } \\
\text { Públicos }\end{array}$ \\
\hline Engenharia Civil (regime noturno) & $18,8 \%$ & $25,0 \%$ & $12,5 \%$ & $12,5 \%$ & $31,2 \%$ \\
\hline Engenharia Civil & $37,5 \%$ & $0,0 \%$ & $37,5 \%$ & $0,0 \%$ & $25,0 \%$ \\
\hline $\begin{array}{l}\text { Gestão da Construção (regime } \\
\text { noturno) }\end{array}$ & $0,0 \%$ & $28,6 \%$ & $14,3 \%$ & $0,0 \%$ & $57,1 \%$ \\
\hline Gestão da Construção & $20,0 \%$ & $60,0 \%$ & $20,0 \%$ & $0,0 \%$ & $0,0 \%$ \\
\hline TOTAL ESTB/IPS & $19,4 \%$ & $25,0 \%$ & $19,4 \%$ & $5,6 \%$ & $30,6 \%$ \\
\hline
\end{tabular}

Fonte: Inquérito por questionário

No que concerne ao setor de atividade, praticamente metade dos diplomados inquiridos $(41,7 \%)$ trabalham em empresas do ramo da indústria transformadora, eletricidade, água e gás e construção de obras públicas. Verifica-se, também, de entre os licenciados que se encontram empregados no setor público, que 19,4\% trabalham em autarquias (administração pública local) e que $11,1 \%$ estão vinculados à administração pública central. O comércio $(16,7 \%)$, os transportes e comunicações $(5,6 \%)$ e os serviços prestados às empresas $(5,6 \%)$ são outros setores de atividade apontados pelos inquiridos.

Relativamente à localização geográfica das entidades empregadoras, Lisboa é o concelho mais referido (45,7\%). O concelho de Setúbal surge, entre estes diplomados, menos representado $(5,8 \%)$ pese embora o distrito representar cerca de $43 \%$. De referir, também, a existência de $8,6 \%$ de licenciados que trabalham em empresas/organizações fora do país, nomeadamente no Brasil, Dinamarca e Moçambique sendo esta taxa representada apenas por licenciados no curso de Engenharia Civil. 
Gráfico 34 - Localização geográfica da empresa/organização onde trabalham os inquiridos licenciados da ESTB/IPS

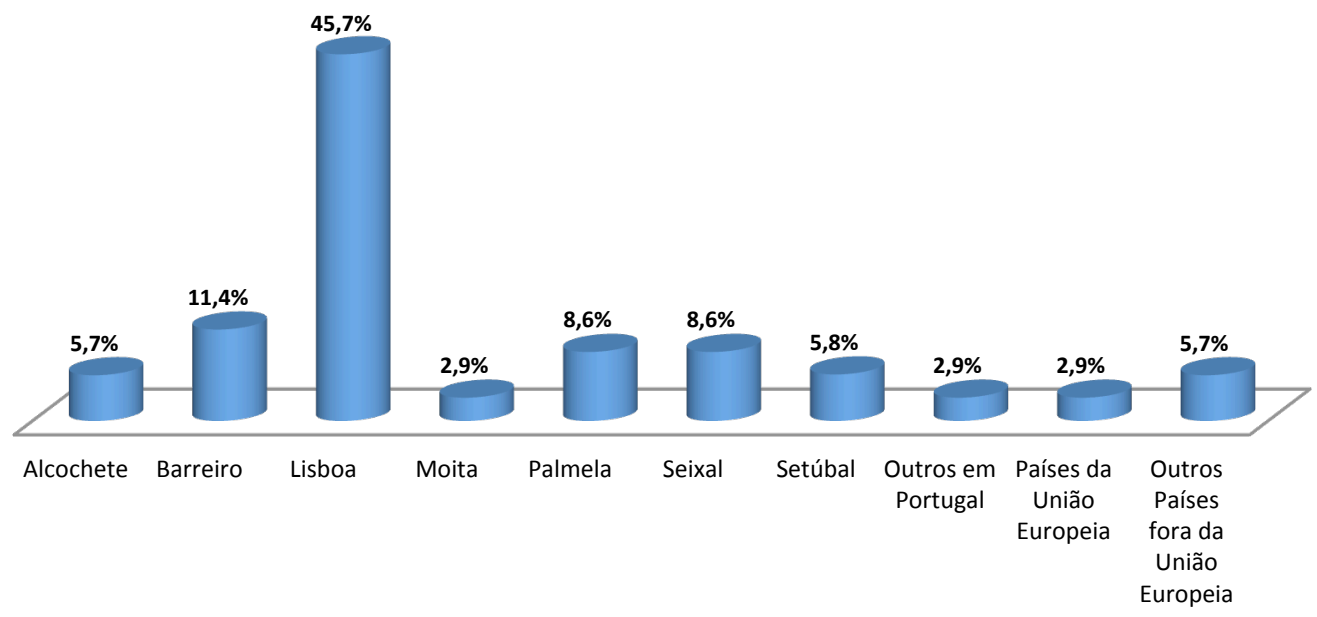

Fonte: Inquérito por questionário

O nível remuneratório onde se insere a grande parte dos licenciados empregados é no escalão 751 - $1.000 €$, que representa cerca de $31,3 \%$ dos inquiridos. No entanto, importa evidenciar que $21,9 \%$ dos inquiridos aufere um salário líquido mensal acima dos $1.250 €$.

É no curso de Engenharia Civil que se encontra a taxa mais alta de licenciados a auferir um salário entre os 251 - $500 €(37,5 \%)$, pese embora $25 \%$ receberem um salário superior a $1.250 €$. Não existem licenciados em Gestão da Construção a auferir menos de $500 €$ mas, o escalão remuneratório mais alto onde se inserem estes diplomados é entre os 1.001 - $1.250 €$.

Quadro 26 - Remuneração mensal líquida, por curso, dos inquiridos licenciados da ESTB/IPS

\begin{tabular}{|c|c|c|c|c|c|}
\hline & $251-500 €$ & $501-750 €$ & $751-1.000 €$ & $\begin{array}{l}1.001- \\
1.250 €\end{array}$ & $\begin{array}{l}\text { Mais de } \\
1.250 €\end{array}$ \\
\hline Engenharia Civil (regime noturno) & $8,3 \%$ & $25,0 \%$ & $25,0 \%$ & $16,7 \%$ & $25,0 \%$ \\
\hline Engenharia Civil & $37,5 \%$ & $0,0 \%$ & $37,5 \%$ & $0,0 \%$ & $25,0 \%$ \\
\hline $\begin{array}{l}\text { Gestão da Construção (regime } \\
\text { noturno) }\end{array}$ & $0,0 \%$ & $28,5 \%$ & $42,9 \%$ & $0,0 \%$ & $28,6 \%$ \\
\hline Gestão da Construção & $0,0 \%$ & $40,0 \%$ & $20,0 \%$ & $40,0 \%$ & $0,0 \%$ \\
\hline TOT A L ESTB/IPS & $12,5 \%$ & $21,9 \%$ & $31,3 \%$ & $12,5 \%$ & $21,9 \%$ \\
\hline
\end{tabular}

Fonte: Inquérito por questionário 


\subsection{3 - Meios de acesso ao emprego}

Para 32\% dos inquiridos, a entrada na vida ativa decorreu de concurso público. A candidatura espontânea (20\%) é também um dos meios de acesso ao mercado de trabalho mais apontados pelos licenciados empregados. De destacar ainda a opção empreendedora de cerca de $16 \%$ dos licenciados, que criaram a sua própria empresa.

Gráfico 35 - Meios de acesso ao emprego dos inquiridos licenciados da ESTB/IPS

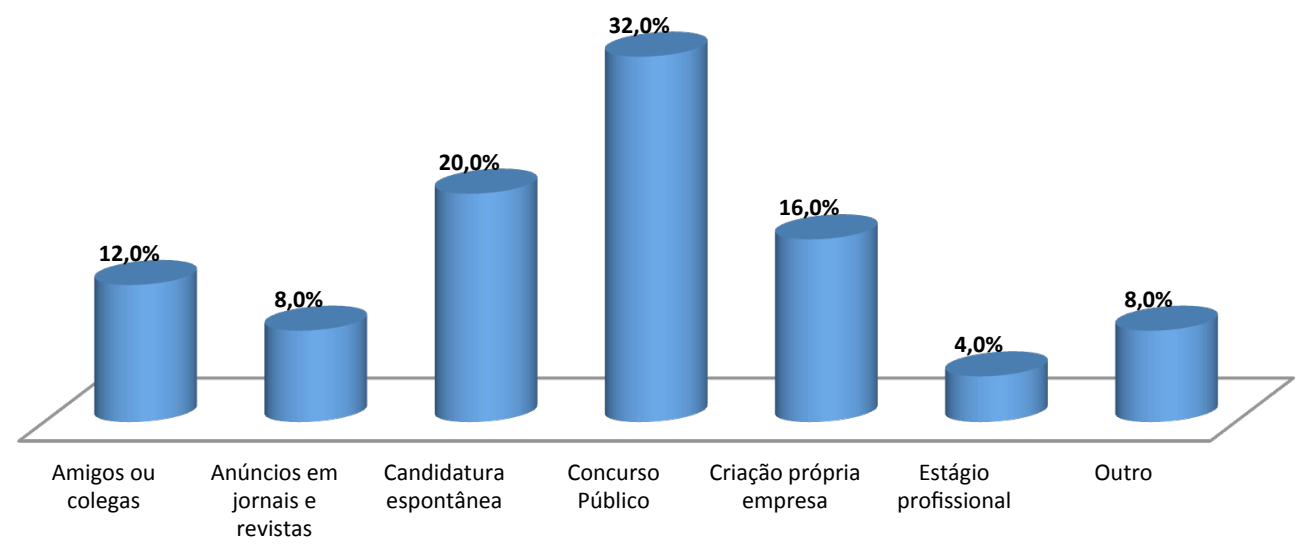

Fonte: Inquérito por questionário

\subsection{4 - Relação entre o emprego e a área de formação académica}

Relativamente à adequação da formação académica às atividades profissionais desenvolvidas, constata-se que $47,2 \%$ dos inquiridos desempenham funções diretamente relacionadas com a sua área de estudo e $25 \%$ indicam exercer as suas atividades profissionais em áreas muito próximas da sua formação académica. São $27,8 \%$ os que indicam trabalhar em áreas completamente distintas.

Os diplomados em Engenharia Civil (regime noturno) e Gestão da Construção são os que no mercado de trabalho encontram uma maior proximidade entre o emprego que detêm e a formação que obtiveram (56,3\% e 57,1\%, respetivamente) sendo os licenciados em Engenharia Civil (regime diurno) os que menor correspondência encontram (25\%). 
Quadro 27 - Relação entre a atividade profissional remunerada dos inquiridos licenciados da ESTB/IPS e a área do curso

\begin{tabular}{|c|c|c|c|}
\hline & $\begin{array}{c}\text { Atividade } \\
\text { diretamente } \\
\text { relacionada com a } \\
\text { área da licenciatura }\end{array}$ & $\begin{array}{l}\text { Atividade numa área } \\
\text { próxima da } \\
\text { licenciatura }\end{array}$ & $\begin{array}{c}\text { Atividade numa área } \\
\text { totalmente diferente } \\
\text { da área da } \\
\text { licenciatura }\end{array}$ \\
\hline Engenharia Civil (regime noturno) & $56,2 \%$ & $31,3 \%$ & $12,5 \%$ \\
\hline Engenharia Civil & $25,0 \%$ & $0,0 \%$ & $75,0 \%$ \\
\hline $\begin{array}{l}\text { Gestão da Construção (regime } \\
\text { noturno) }\end{array}$ & $57,1 \%$ & $42,9 \%$ & $0,0 \%$ \\
\hline Gestão da Construção & $40,0 \%$ & $20,0 \%$ & $40,0 \%$ \\
\hline TO TAL ESTB/IPS & $47,2 \%$ & $25,0 \%$ & $27,8 \%$ \\
\hline
\end{tabular}

Entre os licenciados em Engenharia Civil a profissão mais apontada pelos inquiridos é a de Engenheiro Civil, Engenheiro Geógrafo, Medidor/Orçamentista, Fiscal de Construção Civil, Desenhador. No entanto, alguns destes licenciados referem ser, Técnico Comercial, Administrativo, Operador de Caixa de Supermercado.

Relativamente aos licenciados em Gestão da Construção verifica-se que aqueles que ocupam uma função diretamente ligada à área de estudo indicam ser Projetista, Fiscal de Obras, Encarregado de Construção e Topógrafo. A profissão de Técnico Administrativo surge entre os que exercem a sua atividade profissional numa área distinta da área de formação académica.

\section{6 - Escola Superior de Saúde}

O universo dos diplomados que participaram no estudo é, maioritariamente feminino (87\%), sendo apenas $13 \%$ os diplomados inquiridos do género masculino.

No curso de Terapia da Fala a composição da amostra é 100\% feminina. Nas licenciaturas em Enfermagem e Fisioterapia apesar de existirem inquiridos do género masculino (6,1\% e $28 \%$, respetivamente) os diplomados são essencialmente do género feminino (93,9\% e $72 \%$, respetivamente). 
Gráfico 36 - Distribuição dos inquiridos licenciados da ESS/IPS por curso e género

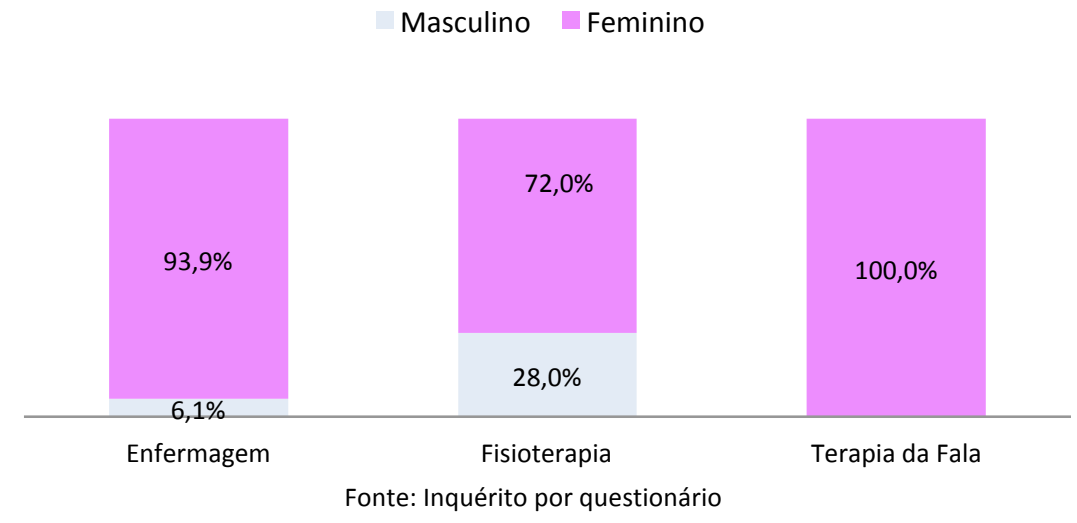

\subsection{1 - Situação Profissional}

No que diz respeito à situação profissional, conclui-se que cerca de $78,3 \%$ dos inquiridos se encontram atualmente empregados e 7,2\% realizam estágio profissional, não se verificando licenciados a prosseguirem os seus estudos a tempo inteiro.

O desemprego é de 14,5\%, com maior expressão entre os inquiridos do género masculino (22,2\%). A taxa de emprego entre as mulheres é de $80 \%$, estando atualmente desempregadas $11,1 \%$.

Gráfico 37 - Situação profissional dos inquiridos licenciados da ESS/IPS por género Homens Mulheres

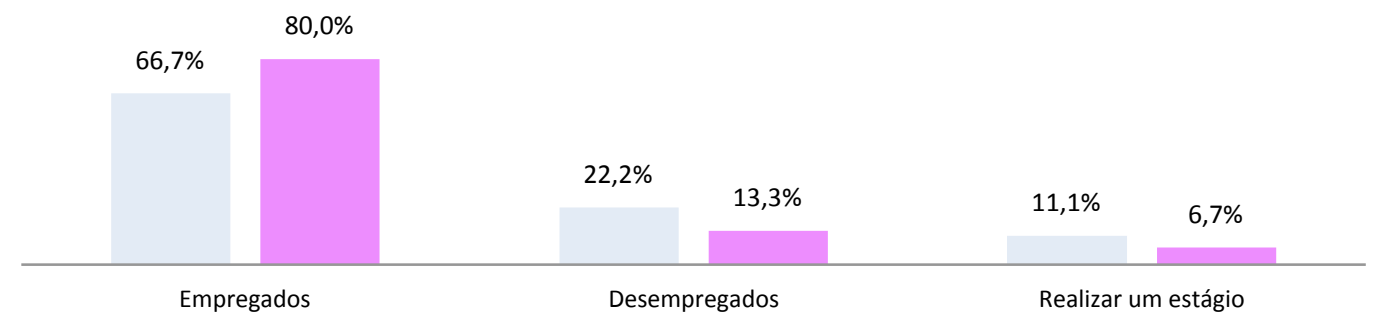

Fonte: Inquérito por questionário

Como se pode observar, no quadro infra, a taxa de inserção profissional entre os diplomados de Terapia da Fala é bastante elevada sendo que 90,8\% se encontram empregados e 9,1\% realizam um estágio profissional. É entre os diplomados inquiridos do curso de Fisioterapia que se regista a taxa de desemprego mais alta (20\%) estando, no entanto, $68 \%$ empregados. 
Quadro 28 - Situação profissional dos inquiridos licenciados da ESS/IPS por curso

\begin{tabular}{|l|c|c|c|}
\hline & Empregado & Realizar estágio & Desempregado \\
\hline Enfermagem & $81,8 \%$ & $3,0 \%$ & $15,2 \%$ \\
\hline Fisioterapia & $68,0 \%$ & $12,0 \%$ & $20,0 \%$ \\
\hline Terapia da Fala & $90,8 \%$ & $9,1 \%$ & $0,0 \%$ \\
\hline T O T A L ESS/IPS & $\mathbf{7 8 , 3 \%}$ & $\mathbf{7 , 2} \%$ & $\mathbf{1 4 , 5 \%}$ \\
\hline
\end{tabular}

Fonte: Inquérito por questionário

O quadro infra apresenta a situação na profissão dos inquiridos empregados permitindo aferir que, não obstante existirem $53,4 \%$ a trabalhar por conta de outrem, cerca de $46,6 \%$ trabalha por conta própria.

O trabalho por conta própria incide, essencialmente, sobre os inquiridos dos cursos de Fisioterapia (60\%) e Terapia da Fala (63,6\%), apresentando menor expressão entre os licenciados em Enfermagem (29,6\%).

Quadro 29 - Situação na Profissão dos inquiridos licenciados da ESS/IPS

\begin{tabular}{|c|c|c|c|}
\hline & $\begin{array}{l}\text { Trabalhador por } \\
\text { conta de outrem }\end{array}$ & $\begin{array}{l}\text { Trabalhador por } \\
\text { conta própria }\end{array}$ & Outra Situação \\
\hline Enfermagem & $70,4 \%$ & $29,6 \%$ & $0,0 \%$ \\
\hline Fisioterapia & $40,0 \%$ & $60,0 \%$ & $0,0 \%$ \\
\hline Terapia da Fala & $36,4 \%$ & $63,6 \%$ & $0,0 \%$ \\
\hline TOTAL ESS/IPS & $53,4 \%$ & $46,6 \%$ & $0,0 \%$ \\
\hline
\end{tabular}

Fonte: Inquérito por questionário

O vínculo contratual predominante entre os licenciados da ESS/IPS é o contrato de prestação de serviços $(37,9 \%)$. Com efeito, a modalidade de trabalho independente, através dos recibos verdes é uma realidade que se traduz, na maioria dos casos, numa situação de vulnerabilidade contratual.

Também o contrato a prazo é o vínculo existente para cerca de $34,5 \%$ dos diplomados inquiridos denotando-se também, que os profissionais de saúde deparam-se no mercado de trabalho com alguma instabilidade contratual. Esta realidade mostra alguma precarização da relação laboral que, na maioria das situações, se configura em recibos verdes ou situações de multiemprego como forma de aumentar as horas de trabalho. 
Com efeito, são os licenciados em Terapia da Fala e Fisioterapia que apresentam maior precariedade no que diz respeito ao vínculo mantido com as entidades empregadores, sendo os licenciados em Enfermagem que encontram maior estabilidade contratual no mercado de trabalho (22,2\% detém contrato de trabalho por tempo indeterminado).

Gráfico 38 - Vínculo laboral dos inquiridos licenciados da ESS/IPS por curso
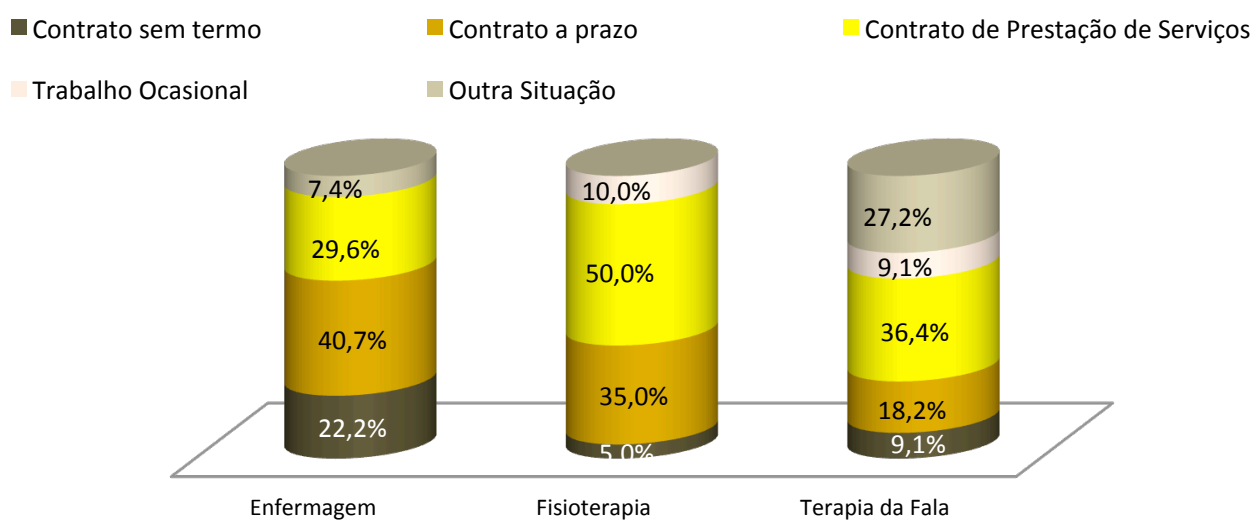

Fonte: Inquérito por questionário

O trabalho a tempo inteiro é praticado por $79,3 \%$ dos licenciados estando, atualmente, $20,7 \%$ a trabalhar a tempo parcial. No entanto, são sobretudo os licenciados em Terapia da Fala que assumem praticar o regime de trabalho a tempo parcial $(36,4 \%)$ sendo os diplomados em Enfermagem que, em maior número, trabalham a tempo inteiro $(88,9 \%)$.

Gráfico 39 - Duração do tempo de trabalho dos licenciados da ESS/IPS por curso

Tempo Inteiro Tempo Parcial

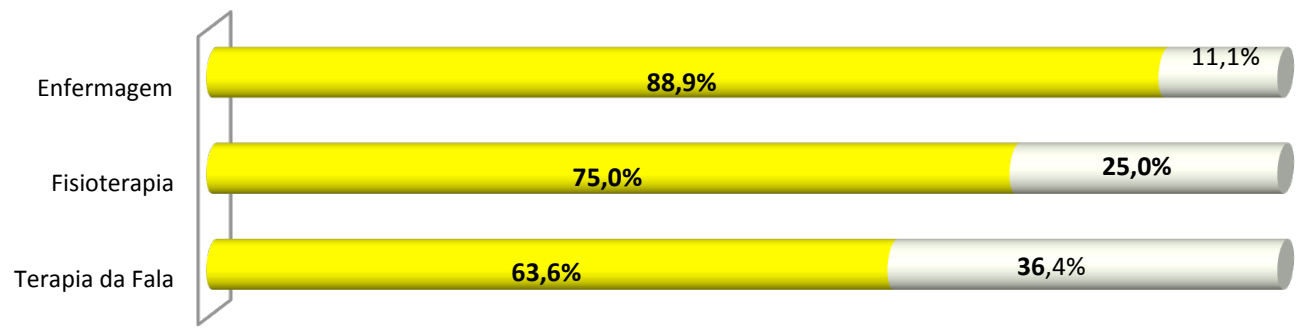

Fonte: Inquérito por questionário 


\subsection{2 - Tipo de empresa/organização, localização geográfica e nível de remuneração}

A Administração Pública assume-se, entre os licenciados da ESS/IPS, como entidade empregadora de $29,9 \%$ dos inquiridos. No entanto, o setor privado surge novamente como o principal empregador $(54,4 \%)$ sendo as empresas com menos de 100 trabalhadores que recrutam o maior número de licenciados na área da saúde (42,1\%). Nas ONG/IPSS também se encontram inseridos 12,3\% destes profissionais de saúde.

Gráfico 40 - Tipo de empresa/organização onde trabalham os inquiridos licenciados da ESS/IPS

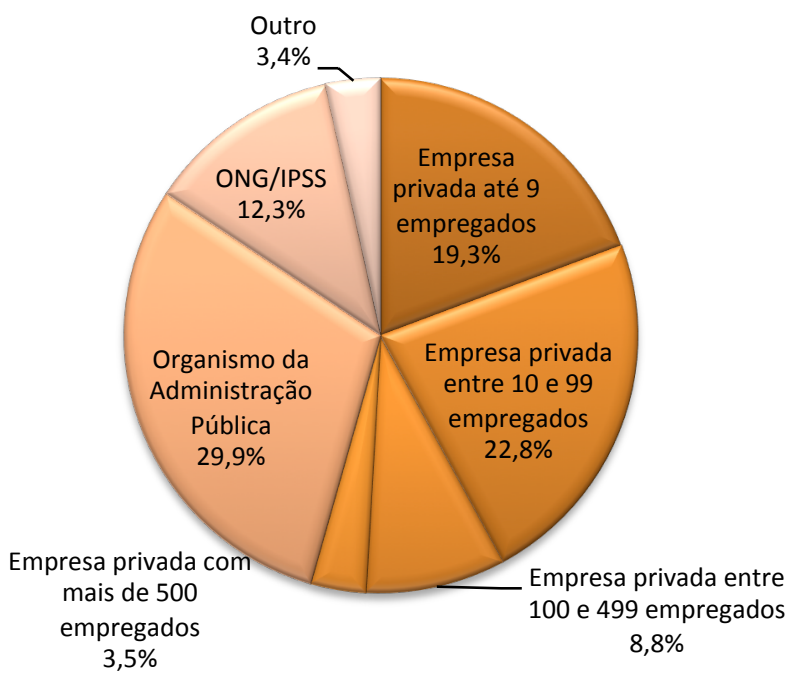

Fonte: Inquérito por questionário

No setor público são essencialmente os diplomados em Enfermagem que se encontram a trabalhar, nomeadamente nos Hospitais e Centros de Saúde (44,4\%). Por outro lado, são os licenciados em Terapia da Fala que se inseriram profissionalmente nas ONG/IPSS (40\%) e, os licenciados em Fisioterapia distribuem-se pelos diferentes setores sendo as empresas privadas as principais empregadoras.

Quadro 30 - Dimensão da empresa/organização onde trabalham os inquiridos licenciados da ESS/IPS, por curso

\begin{tabular}{|c|c|c|c|c|c|c|c|}
\hline & $\begin{array}{c}\text { Empresa } \\
\text { Privada até } 9 \\
\text { trabalhadores }\end{array}$ & $\begin{array}{c}\text { Empresa } \\
\text { Privada entre } \\
10 \text { a } 99 \\
\text { trabalhadores }\end{array}$ & $\begin{array}{c}\text { Empresa } \\
\text { Privada entre } \\
100 \text { a } 499 \\
\text { trabalhadores }\end{array}$ & $\begin{array}{c}\text { Empresa } \\
\text { Privada com } \\
\text { mais de } 500 \\
\text { trabalhadores }\end{array}$ & $\begin{array}{l}\text { Organismos } \\
\text { Públicos }\end{array}$ & ONG/IPSS & Outro \\
\hline Enfermagem & $14,8 \%$ & $11,1 \%$ & $11,1 \%$ & $7,4 \%$ & $44,4 \%$ & $11,1 \%$ & $0,0 \%$ \\
\hline Fisioterapia & $25,0 \%$ & $35,0 \%$ & $10,0 \%$ & $0,0 \%$ & $20,0 \%$ & $0,0 \%$ & $10,0 \%$ \\
\hline Terapia da Fala & $20,0 \%$ & $30,0 \%$ & $0,0 \%$ & $0,0 \%$ & $10,0 \%$ & $40,0 \%$ & $0,0 \%$ \\
\hline TOTAL ESS/IPS & $19,3 \%$ & $22,8 \%$ & $8,8 \%$ & $3,5 \%$ & $29,9 \%$ & $12,3 \%$ & $3,4 \%$ \\
\hline \multicolumn{8}{|c|}{ Fonte: Inquérito por questionário } \\
\hline
\end{tabular}


No que diz respeito ao setor de atividade verifica-se que os licenciados se inserem, sobretudo, no setor da saúde e ação social $(89,7 \%)$ estando os restantes inquiridos distribuídos pelo setor da educação $(5,2 \%)$, comércio $(1,7 \%)$, justiça $(1,7 \%)$ e outros $(1,7 \%)$.

Relativamente à localização geográfica das entidades empregadoras, verifica-se uma grande dispersão dos licenciados por vários concelhos do país $(30,8 \%)$ existindo no entanto, a concentração de $30,8 \%$ destes licenciados no concelho de Lisboa. O concelho de Setúbal surge, entre estes diplomados, menos representado $(13,5 \%)$ pese embora o distrito representar cerca de 30,6\%. De referir, também, a existência de 7,7\% de licenciados que trabalham em empresas/organizações fora do país, nomeadamente em França e Reino Unido, sendo essencialmente os diplomados em Enfermagem que procuram o emprego fora de Portugal.

Gráfico 41 - Localização geográfica da empresa/organização onde trabalham os inquiridos licenciados da ESS/IPS

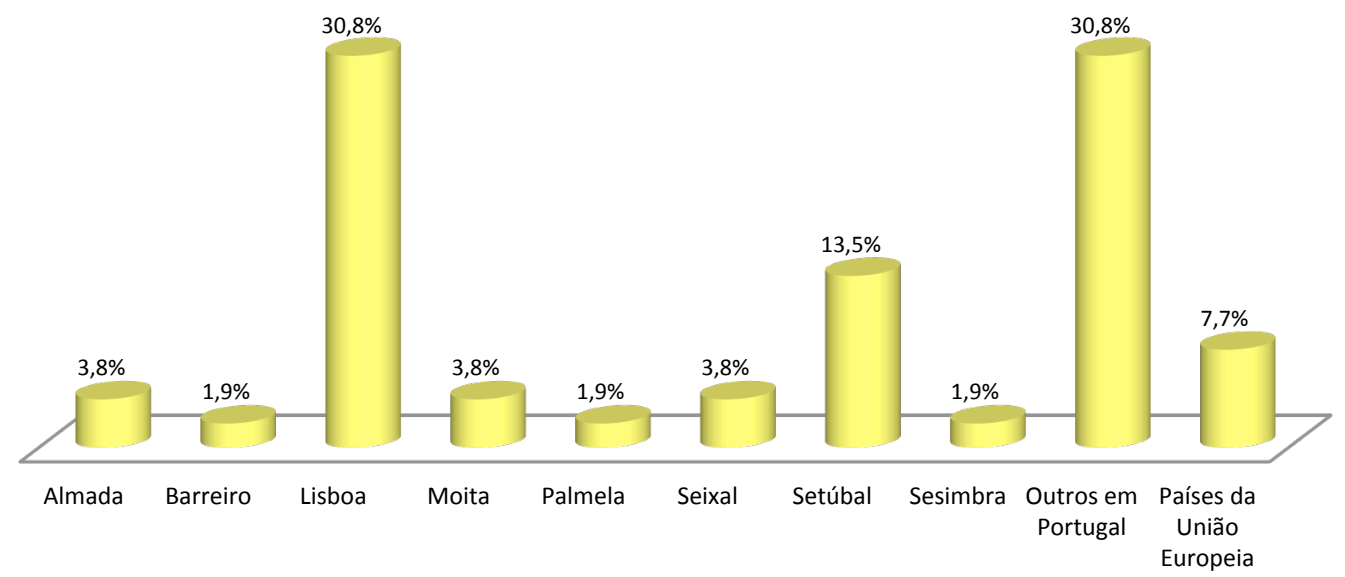

Fonte: Inquérito por questionário

Os licenciados na área de saúde auferem, em média, entre 751 - $1.000 €$ líquidos mensais, sendo $47,2 \%$ os inquiridos que se encontram neste escalão. No curso de Enfermagem, são apenas $16 \%$ os que recebem um salário líquido mensal inferior a 751€. No escalão mais alto, onde o rendimento é superior a $1.250 €$ encontram-se os licenciados em Enfermagem (16\%) e em Fisioterapia (5,6\%). 
Quadro 31 - Remuneração mensal líquida, por curso, auferida pelos inquiridos licenciados da ESS/IPS

\begin{tabular}{|c|c|c|c|c|c|c|}
\hline & Até $250 €$ & $251-500 €$ & $501-750 €$ & $751-1.000 €$ & $\begin{array}{l}1.001- \\
1.250 €\end{array}$ & $\begin{array}{c}\text { Mais de } \\
1.250 €\end{array}$ \\
\hline Enfermagem & $4,0 \%$ & $4,0 \%$ & $8,0 \%$ & $60,0 \%$ & $8,0 \%$ & $16,0 \%$ \\
\hline Fisioterapia & $0,0 \%$ & $5,6 \%$ & $44,4 \%$ & $33,3 \%$ & $11,1 \%$ & $5,6 \%$ \\
\hline Terapia da Fala & $0,0 \%$ & $20,0 \%$ & $40,0 \%$ & $40,0 \%$ & $0,0 \%$ & $0,0 \%$ \\
\hline TO T A L ESS/IPS & $1,9 \%$ & $7,5 \%$ & $26,4 \%$ & $47,2 \%$ & $7,5 \%$ & $9,4 \%$ \\
\hline
\end{tabular}

\subsection{3 - Meios de acesso ao emprego}

A candidatura espontânea surge, entre os licenciados na ESS/IPS como o principal meio de acesso ao emprego (33,3\%). No entanto, o estágio, nas suas diferentes formas (curricular, profissional e não remunerado), apresenta-se como o meio de inserção na vida ativa para $14,1 \%$ destes licenciados. Destaca-se, ainda, que para $8,8 \%$ dos inquiridos a entrada no mercado de trabalho deu-se através da criação da própria empresa o que, de certa forma, consubstancia os resultados atinentes à situação na profissão (37\% trabalham com contrato prestação de serviços/recibos verdes).

Gráfico 42 - Meios de acesso ao emprego dos inquiridos licenciados da ESS/IPS

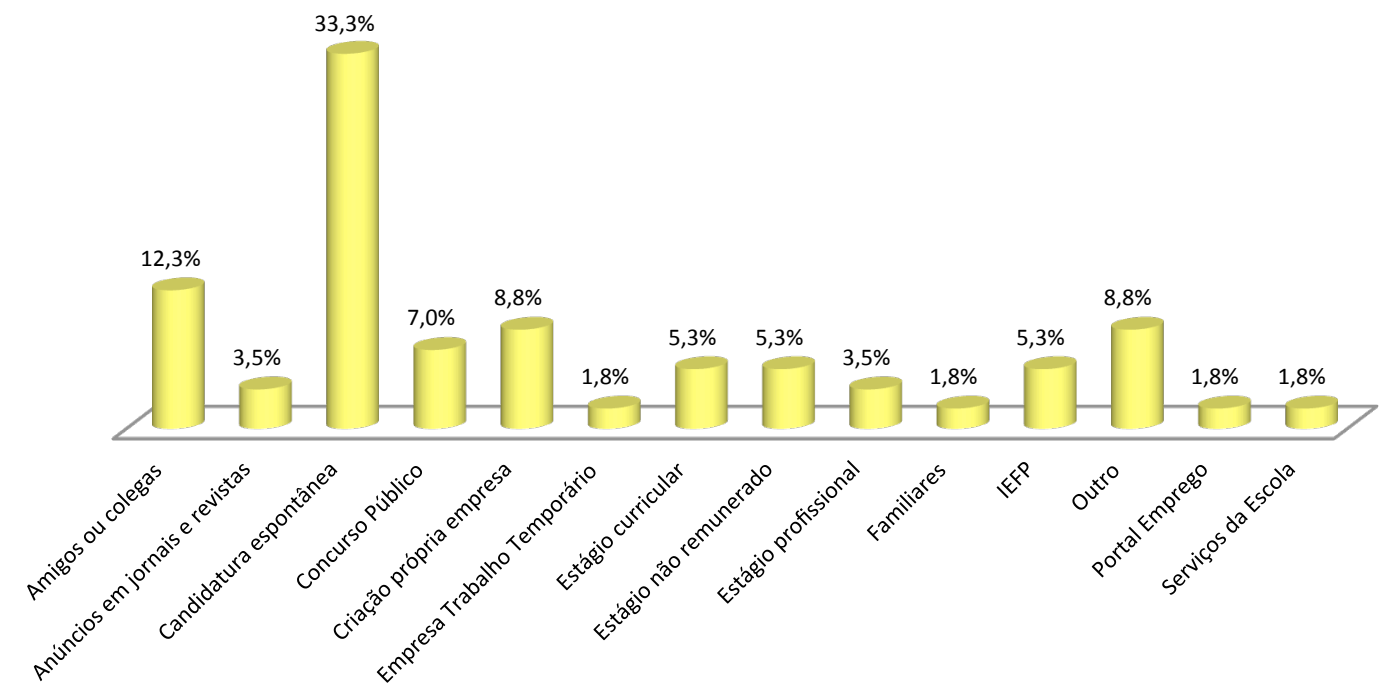

Fonte: Inquérito por questionário 


\subsection{4 - Relação entre o emprego e a área de formação académica}

Os licenciados da ESS/IPS apresentam uma relação muito próxima entre a formação académica obtida e a atividade profissional que exercem, sendo $94,8 \%$ os que maior correspondência encontram entre o mercado de trabalho onde se inserem e a área de estudo. Com efeito, todos os inquiridos licenciados em Terapia da Fala trabalham na sua área de formação. Apenas o curso de Enfermagem apresenta uma taxa de $3,7 \%$ de inquiridos que indicam desenvolver a sua atividade profissional numa área completamente distinta do curso em que se licenciaram.

Quadro 32 - Relação entre a atividade profissional remunerada dos inquiridos licenciados da ESS/IPS e a área do curso

\begin{tabular}{|c|c|c|c|}
\hline & $\begin{array}{c}\text { Atividade } \\
\text { diretamente } \\
\text { relacionada com a } \\
\text { área da licenciatura }\end{array}$ & $\begin{array}{l}\text { Atividade numa área } \\
\text { próxima da } \\
\text { licenciatura }\end{array}$ & $\begin{array}{c}\text { Atividade numa área } \\
\text { totalmente diferente } \\
\text { da área da } \\
\text { licenciatura }\end{array}$ \\
\hline Enfermagem & $96,3 \%$ & $0,0 \%$ & $3,7 \%$ \\
\hline Fisioterapia & $90,0 \%$ & $10,0 \%$ & $0,0 \%$ \\
\hline Terapia da Fala & $100,0 \%$ & $0,0 \%$ & $0,0 \%$ \\
\hline TO T A L ESS/IPS & $94,8 \%$ & $3,4 \%$ & $1,7 \%$ \\
\hline
\end{tabular}

Fonte: Inquérito por questionário

Na generalidade, os licenciados da ESS/IPS trabalham em áreas diretamente ligadas à sua formação académica pelo que, encontramos uma relação estreita entre a profissão destes inquiridos e o diploma que os mesmos obtiveram. Com efeito, entre os licenciados em Enfermagem a profissão mais apontada é a de Enfermeiro e, na licenciatura em Fisioterapia, é a de Fisioterapeuta, apesar de existir um pequeno grupo que indica desempenhar funções administrativas e de auxiliar de ação médica. Na licenciatura em Terapia da Fala todos os inquiridos trabalham como Terapeuta da Fala. 


\section{CONCLUSÕES}

Apesar do aumento progressivo de diplomados no ensino superior o atual contexto de crise tem condicionado os processos de inserção profissional dos licenciados no mercado de trabalho. 0 presente trabalho teve como principal objetivo analisar o percurso profissional dos licenciados no IPS no ano letivo 2010/2011 tendo sido apresentado, ao longo do relatório, os resultados obtidos por cada escola do IPS, tendo em conta as especificidades que cada curso oferece. Pretende-se assim, apresentar as conclusões encontradas em termos gerais e, sempre que possível complementar com algumas evidências teóricas.

Os diplomados do IPS são maioritariamente mulheres, que correspondem a 56\% dos participantes no estudo, encontrando-se sobre representadas na ESS/IPS (87\%), ESE/IPS (79\%) e ESCE/IPS (60\%). Os licenciados do género masculino, que representam $44 \%$ da amostra apresentam-se, maioritariamente, na ESTB/IPS (83\%) e na ESTS/IPS (71\%). Esta realidade parece traduzir a realidade do ensino superior em Portugal, com existência de áreas tipicamente masculinas (sobretudo as engenharias clássicas, tecnologias e o deporto) em contraposição com ocupações e áreas mais femininas (saúde, educação, biomédica, ambiente e ciências empresariais).

Como se pode aferir ao longo do relatório, os processos de transição da escola para o mercado de trabalho são influenciados por um conjunto de variáveis, sendo o curso e o género os que apresentam evidencias mais vincadas.

No que concerne à situação profissional dos licenciados intervenientes no estudo conclui-se que cerca de $67 \%$ estão atualmente empregados. Contudo, não se pode deixar de referir as assimetrias existentes entre as diversas escolas do IPS e, sobretudo, entre os diversos cursos ministrados, conforme se verifica através dos dados apresentados por escola. Com efeito, é a ESCE/IPS e a ESS/IPS que apresentam as taxas de emprego mais altas (71,2\% e 78,3\%, respetivamente), sendo no entanto alguns dos cursos ministrados na ESTS/IPS a apresentarem níveis de emprego mais altos, nomeadamente em Engenharia da Automação, Instrumentação e Controlo, Engenharia Informática, Tecnologia e Gestão Industrial regime noturno, onde $100 \%$, $90 \%$ e $83,3 \%$ dos inquiridos, respetivamente, estão inseridos no mercado de trabalho o que, de certa forma, consubstancia o preconizado por Alves (2007), quando refere que alguns domínios disciplinares nas áreas das Engenharias e Informática oferecem melhores oportunidades de inserção profissional. De referir também que $7,7 \%$ dos licenciados estão atualmente a realizar estágio profissional e 7,4\% estudam a tempo inteiro.

Ao efetuarmos uma análise da situação profissional dos licenciados, por género, os resultados evidenciam que efetivamente são as mulheres que encontram maiores dificuldades de entrada na 
vida ativa, confirmando-se assim a existência de assimetrias de género no mercado de trabalho, tal como refere Gonçalves et al (2006). Com efeito, do universo de mulheres licenciadas que participaram no estudo, $60,5 \%$ estão empregadas sendo, $75,1 \%$ os homens licenciados que estão empregados. Por outro lado, na relação efetuada entre a variável género e a opção de estudar a tempo inteiro são, de facto, as mulheres que em maior número apostam na prossecução dos seus estudos ao nível do mestrado $(9,1 \%$ mulheres estudam a tempo inteiro e $5,2 \%$ dos homens estudam a tempo inteiro).

Também a nota final obtida na licenciatura parece condicionar os processos de integração no mercado de trabalho, uma vez que de entre os estudantes desempregados $58,9 \%$ obtiveram uma média final de curso inferior a 14.

Relativamente à situação na profissão $85,2 \%$ dos licenciados empregados trabalham por conta de outrem sendo apenas $13,6 \%$ os que assumem trabalhar por conta própria. Em termos de vínculo, deparamo-nos com uma diversidade de estatutos contratuais. O contrato de trabalho que oferece maior estabilidade, o contrato por termo indeterminado ou sem termo, é a realidade de $47,3 \%$ dos licenciados que trabalham por conta de outrem. Contudo, os vínculos que assumem maior precariedade no mercado de trabalho, o contrato com termo e o contrato de prestação de serviços, são a realidade de $37,1 \%$ e $11,2 \%$, respetivamente, dos licenciados empregados, sendo o espelho das profundas alterações que o mercado de trabalho português e europeu têm vivenciado desde 2007 (OCDE, 2012).

No entanto, também no que diz respeito ao vínculo contratual, existem diferenças por escola e curso. São, efetivamente, os diplomados na ESTS/IPS e na ESTB/IPS que encontram uma maior estabilidade no contrato mantido com as entidades empregadoras tendo em conta que, $61,9 \%$ (ESTS/IPS) e 69,4\% (ESTB/IPS) destes licenciados trabalham com contrato por tempo indeterminado. Por outro lado, são sobretudo os licenciados na ESS/IPS que apresentam maior diversificação de vínculo contratual verificando-se que encontram, em contexto de trabalho, maior vulnerabilidade contratual uma vez que $34,5 \%$ possuem um contrato a termo certo e $37,9 \%$ um contrato de prestação de serviços. No entanto, o trabalho a tempo inteiro é praticado por $88,1 \%$ dos licenciados empregados.

Na associação efetuada entre o vínculo laboral e o género, verifica-se a existência de uma relação significativa denotando-se diferenças substanciais. Importa referir que, $61,9 \%$ dos homens licenciados empregados trabalham com um contrato por tempo indeterminado, existindo apenas $33,3 \%$ das mulheres que usufruem das mesmas condições. Com efeito, conforme sustentam Guerreiro e Perista (2006) são as mulheres que encontram, no mercado de trabalho, menores oportunidades de carreira, sendo as mais abrangidas pela precariedade laboral. 
O setor privado assume-se como principal empregador destes licenciados (74\%) sobretudo nas pequenas e médias empresas (44\%). As empresas privadas com mais de 99 trabalhadores empregam cerca de $29 \%$ dos licenciados. O setor público surge, para cerca de $21 \%$ dos diplomados, como o principal empregador sendo essencialmente os estudantes provenientes da ESTB/IPS e da ESS/IPS que trabalham na administração pública. As principais empresas empregadoras são essencialmente as da saúde e ação social $(16,8 \%)$, do setor dos serviços prestados (16\%), da indústria transformadora $(14,3 \%)$, do comércio $(14,1 \%)$ e dos transportes e comunicações $(9,1 \%)$.

Relativamente ao concelho onde estão inseridas as empresas/organizações onde trabalham os licenciados verifica-se que $51,2 \%$ operam no distrito de Setúbal, sendo $31,4 \%$ as que se situam no concelho de Lisboa. Por outro lado, destaca-se ainda que, atualmente, $2 \%$ dos inquiridos empregados trabalham fora do país nomeadamente no Brasil, Dinamarca, França, Moçambique, Reino Unido e República Checa sendo, sobretudo, os licenciados nas áreas da Engenharia e Saúde que se encontram inseridos no mercado de trabalho internacional.

No que concerne ao salário líquido mensal auferido pelos licenciados empregados, os resultados corroboram algumas evidências teóricas. Com efeito, cerca de 56\% dos licenciados aufere entre $751 €$ e $1.000 €$ líquidos mensais, existindo $12,2 \%$ a receber um salário superior a $1.250 €$. Na análise da relação entre o tipo de contrato de trabalho e o salário auferido conclui-se, ainda, que cerca de 72\% dos licenciados empregados com contrato de trabalho por tempo indeterminado recebem uma remuneração mensal superior a $750 €$ sendo que, para os trabalhadores que detém um contrato de trabalho a prazo essa remuneração só é auferida por 40,1\%. Também Marques (2009), nos seus estudos, refere que a remuneração média dos jovens licenciados oscila entre os $501 €$ e os $1.000 €$ existindo uma relação significativa entre o salário e o vínculo contratual.

Alves (2005) aponta ainda a área de estudo e a classificação final na licenciatura como influenciadores do salário auferido pelo que se observa entre os licenciados no IPS que são, de facto, os diplomados na ESTS/IPS e na ESTB/IPS que recebem os salários mais altos (superiores a $1.250 €)$ concluindo-se, que são os licenciados nas áreas da engenharias que encontram, no mercado de trabalho, não só vínculos contratuais que oferecem maior estabilidade profissional, mas também salários acima da média. Neste caso concreto, estes licenciados, parecem beneficiar de um tecido empresarial fortemente internacionalizado, quer pela natureza multinacional das empresas quer pela forte componente exportadora de muitas das empresas portuguesas existentes na região de influência do IPS, com práticas salariais alinhadas com a realidade internacional e sujeitas a outro tipo de regras e práticas. Por outro lado, na associação efetuada entre o salário e a nota final da licenciatura não obtivemos relação significativa. 
Contudo, é na análise por género que as assimetrias voltam a evidenciar-se, pelo que os resultados obtidos vêm confirmar justamente as diferenças dos níveis salariais entre os géneros já referidos na literatura. Ora, nos escalões mais baixos de remuneração (abaixo dos $750 €$ ) são essencialmente as mulheres que se encontram inseridas (56\%) existindo apenas $12,5 \%$ de homens licenciados a receber mensalmente um salário inferior a $750 €$. Com uma remuneração mensal superior a $1.000 €$ estão cerca de $32,6 \%$ de homens licenciados e, 7,5\% de mulheres licenciadas. Se se acrescentar a este fator o desemprego mais elevado entre as mulheres, constata-se uma discriminação de género, quer no acesso ao mercado de trabalho quer na capacidade de obtenção de salários mais elevados. Esta situação deve-se interpelar a dois níveis. Por um lado, se é verdade que existe uma crescente feminização no ensino superior, importa perceber até que ponto as escolhas efetuadas na frequência dos vários cursos condiciona, e de que forma, os percursos profissionais dos diplomados. Adicionalmente, esta situação deverá convocar os diversos atores para o reforço de instrumentos de política que mitiguem ou eliminem a maior vulnerabilidade das mulheres no mercado de trabalho.

Quando se relaciona o tipo de empresa/organização onde trabalham os licenciados, com a remuneração auferida, conclui-se que são sobretudo as empresas com mais de 100 trabalhadores que pagam um salário superior a 1.250€. Os licenciados que trabalham na Administração Pública auferem um salário que oscila entre os $751 €$ e os $1.250 €$ (salário auferido nas categorias de Assistente Técnico e Técnico Superior), e são as PME's que na sua maioria apresentam uma tabela salarial com maior expressão entre os 501€ - $1.000 €$.

A integração na vida ativa, com sucesso, depende em grande medida da relação existente entre a área de formação do diplomado e a profissão desempenhada. À semelhança dos resultados obtidos, por Alves (2005), no seu estudo junto dos diplomados da Universidade de Lisboa, também os licenciados no IPS apresentam uma importante correspondência entre a licenciatura e o emprego $(59,2 \%)$ existindo ainda $15,3 \%$ dos diplomados que trabalham em áreas afins. No entanto, são sobretudo os licenciados na área da saúde que apresentam uma relação muito significativa entre as atividades profissionais que desenvolvem e a área académica onde se diplomaram.

A partir dos dados obtidos é possível afirmar que, os licenciados empregados inseriram-se no mercado de trabalho através de um diversificado conjunto de meios, verificando-se que 22,9\% já tinham uma profissão no decorrer do percurso académico e mantiveram-no até ao momento, 0 que, de certo modo, vem consubstanciar algumas evidências teóricas existentes que defendem que a prossecução dos estudos ao nível superior tem como principal objetivo a consolidação e progressão numa profissão já adquirida (Oliveira e Temudo, 2008). A candidatura espontânea surge, para $19,3 \%$ dos inquiridos, como o meio utilizado na procura e acesso ao emprego logo 
seguido do grupo de amigos e colegas $(9,8 \%)$, da resposta a anúncios $(8,6 \%)$, de concurso público $(7,7 \%)$ e do estágio curricular $(7,1 \%)$.

$\mathrm{Na}$ análise por escola verifica-se que são os licenciados na ESE/IPS e ESS/IPS que mais recorrem à rede amigos e familiares sendo este, de acordo com Marques (2007), um dos meios privilegiados para o acesso ao emprego e que se prende, de certa forma, com a origem social dos diplomados.

O estágio curricular foi a porta de entrada na vida ativa para alguns dos licenciados, e especificamente para $13,9 \%$ dos diplomados na ESCE/IPS, corroborando as conclusões de Almeida et al (2007) e Marques (2009), em que amiúde o estágio curricular se traduz num meio privilegiado no acesso ao emprego. 


\section{Bibliografia}

ALMEIDA, A., MARQUES, A., VAZ, I. e DOMINGUINHOS, P. (2007). Inserção Profissional dos Licenciados pela ESCE. Setúbal, ESCE.

ALVES, M. G. (2009). Ensino superior, trabalho e emprego na actual sociedade de risco: um olhar sobre o caso de mestres e doutores. Sociologia, problemas e práticas, 59, 107-124.

ALVES, M. G. (2004). Inserção Profissional de Diplomados de Ensino Superior - uma abordagem sociológica. Actas dos ateliers do Vo Congresso Português de Sociologia, pp. 119.124.

ALVES, M. G. (2005). Como se entrelaçam a educação e o emprego? Contributos da investigação sobre Licenciados, Mestres e Doutores. Interacções, no. 1, pp. 179-201.

ALVES, M. G. (2005). Inserção profissional de diplomados de ensino superior numa perspectiva educativa. Formação Profissional, no 34, Bruxelas, Cedefop, pp. 31-44.

ALVES, M. G., AMBRÓSIO, M. (2005). Observatórios de inserção e acompanhamento profissional: Um instrumento na interaç̧ão entre sistema de ensino e formação e sistema de emprego. Actas do IIIํ Congresso Português de Sociologia.

ALVES, N. (2005), Trajectórias Académicas e de Inserção Profissional dos Licenciados pela Universidade de Lisboa 1999-2003. Lisboa: Gabinete de Apoio ao Estudante/Reitoria da Universidade de Lisboa.

CASTILLO, G. (2000). De la universidad al puesto de trabajo. Madrid. Pirámide.

CHAVES, M., MORAIS, C., SEDAS, J. (2011). Os diplomados do ensino superior perante o mercado de trabalho: velhas teses catastrofistas, aquisições recentes. Fórum Sociológico, 17, 1-25.

COSTA, C. (2011). As práticas de gestão de recursos humanos que conciliam a tripla jornada: a perspectiva dos trabalhadores estudantes do ensino superior. Dissertação de Mestrado, Instituto Politécnico de Setúbal.

FIGUEIRA, E., SILVA, S., RAINHA, L. (2004). Participação na formação contínua: uma necessidade para uma empregabilidade sustentável na região do Alentejo. Actas dos ateliers do o Congresso Português de Sociologia, 39-43.

GONÇALVES, F., et al (2006). Percursos de empregabilidade dos licenciados - perspectivas europeias e nacional. Análise Psicológica, 1 (XXIV), pp. 99-114.

GUERREIRO, M. D. e PEREIRA, I. (2006). Responsabilidade Social das Empresas, Igualdade e Conciliação Trabalho-Família - Experiências do Prémio Igualdade é Qualidade. Lisboa, CITE.

GUERREIRO, M. D. e ABRANTES, P. (2007). Transições Incertas - Os jovens perante o trabalho e a família. 2. a edição, Lisboa, CITE.

GUERREIRO, M. D., et al. (2006b), Os jovens e o Mercado de Trabalho. Caracterização, estrangulamentos à integração efectiva na vida activa e a eficácia das políticas. Lisboa: DGEEP.

MARQUES, Ana P. (2009). "Novas" legitimidades de segmentação do mercado de trabalho de jovens diplomados. Revista Portuguesa de Educação, 22 (2), pp. 85-115.

MARQUES, Ana P. (2007). Melntegra - Mercados e estratégias de inserção profissional. Licenciados versus empresas da Região Norte. Relatório final. 
MARQUES, A. P. (2001). Dinâmicas da relação entre trabalho e emprego: o fetiche da "empregabilidade permanente». Sociedade e Cultura 3, Cadernos do Noroeste, Série Sociologia, 16 (1-2), 167-186.

OCDE (2012), Education at a Glance 2012. Highlights, OECD Publishing. Disponível em http://dx.doi.org/10.1787/eag_highlights-2012-en (consultado em 31/01/2013).

OLIVEIRA, M. e TEMUDO, E. (2008). Mulheres Estudantes Trabalhadoras na Universidade do Porto - Uma Licenciatura 'fora de tempo' ou 'sem tempo'?. Ex-aequo, n.o 18, pp. 147-173.

PINTO, E. (2012). Transição para o mercado de trabalho dos licenciados da Escola de Economia e Gestão da Universidade do Minho. Dissertação de Mestrado, Universidade do Minho.

SAÚDE, S., DELGADO, A. (2004). Empregabilidade e novas competências: Identificação de perfis e de factores de limitação à inserção profissional dos estudantes do ensino superior politécnico - um estudo de caso. Actas dos ateliers do Vo Congresso Português de Sociologia, 99-105.

SILVA, B., MARQUES, F. (2001). "Trajectórias de inserção profissional dos licenciados em Educação pelo Instituto de Educação e Psicologia da Universidade do Minho", in Albertino GONÇALVES, et al, (2006). Da universidade para o mundo do trabalho, desafios para um diálogo. Braga: Universidade do Minho, pp. 205-206.

TOMLINSON, M. (2012). Graduate Employability: A review of conceptual and empirical themes. Higher Education Policy, 25, (407-431).

VINAgREIRO, M. (2008). Origem Social e Trajectória Profissional. Observatório do percurso dos diplomados pela Faculdade de Ciências do Desporto e Educação Física da Universidade de Coimbra. 